Portland State University

PDXScholar

\title{
Evaluating the Distributional Effects of Regional Transportation Plans and Projects
}

Kristine Williams

University of South Florida

Aaron Golub

Portland State University

Follow this and additional works at: https://pdxscholar.library.pdx.edu/trec_reports

Part of the Transportation Commons, Transportation Engineering Commons, Urban Studies Commons, and the Urban Studies and Planning Commons Let us know how access to this document benefits you.

\section{Recommended Citation}

Williams, K. and Golub, A. Evaluating the Distributional Effects of Regional Transportation Plans and Projects. NITC-RR-862. Portland, OR: Transportation Research and Education Center (TREC), 2017. https://doi.org/10.15760/trec.175

This Report is brought to you for free and open access. It has been accepted for inclusion in TREC Final Reports by an authorized administrator of PDXScholar. Please contact us if we can make this document more accessible: pdxscholar@pdx.edu. 


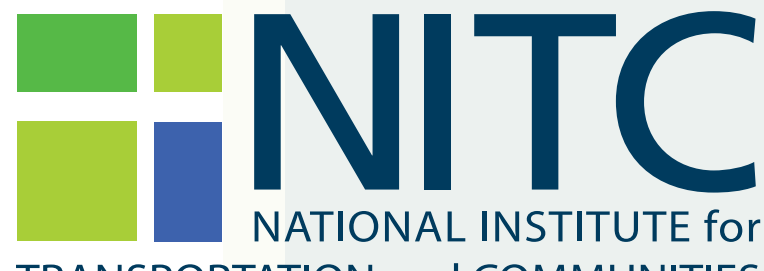

TRANSPORTATION and COMMUNITIES

FINAL REPORT

Evaluating the Distributional Effects of Regional Transportation Plans and Projects

NITC-RR-862 June 2017

NITC is a U.S. Department of Transportation national university transportation center.

=H:IREC 


\title{
EVALUATING THE DISTRIBUTIONAL EFFECTS OF REGIONAL TRANSPORTATION PLANS AND PROJECTS
}

\author{
Final Report \\ NITC-RR-862 \\ by \\ Kristine M. Williams, AICP \\ University of South Florida \\ Center for Urban Transportation Research \\ Aaron Golub, PhD \\ Nohad A. Toulan School of Urban Studies and Planning \\ Portland State University \\ for \\ National Institute for Transportation and Communities (NITC) \\ P.O. Box 751 \\ Portland, OR 97207
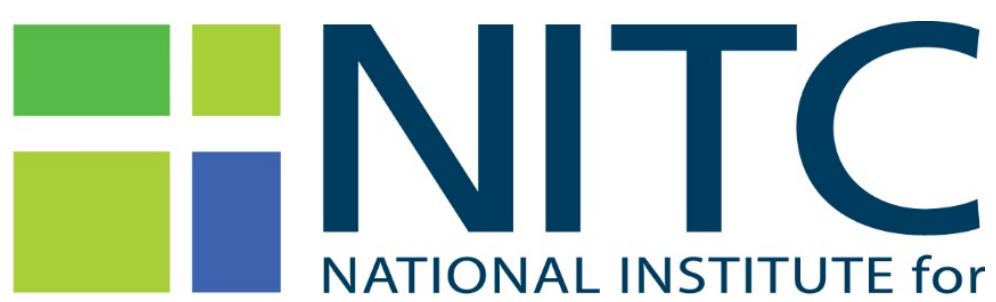 \\ TRANSPORTATION and COMMUNITIES
}

May 2017 


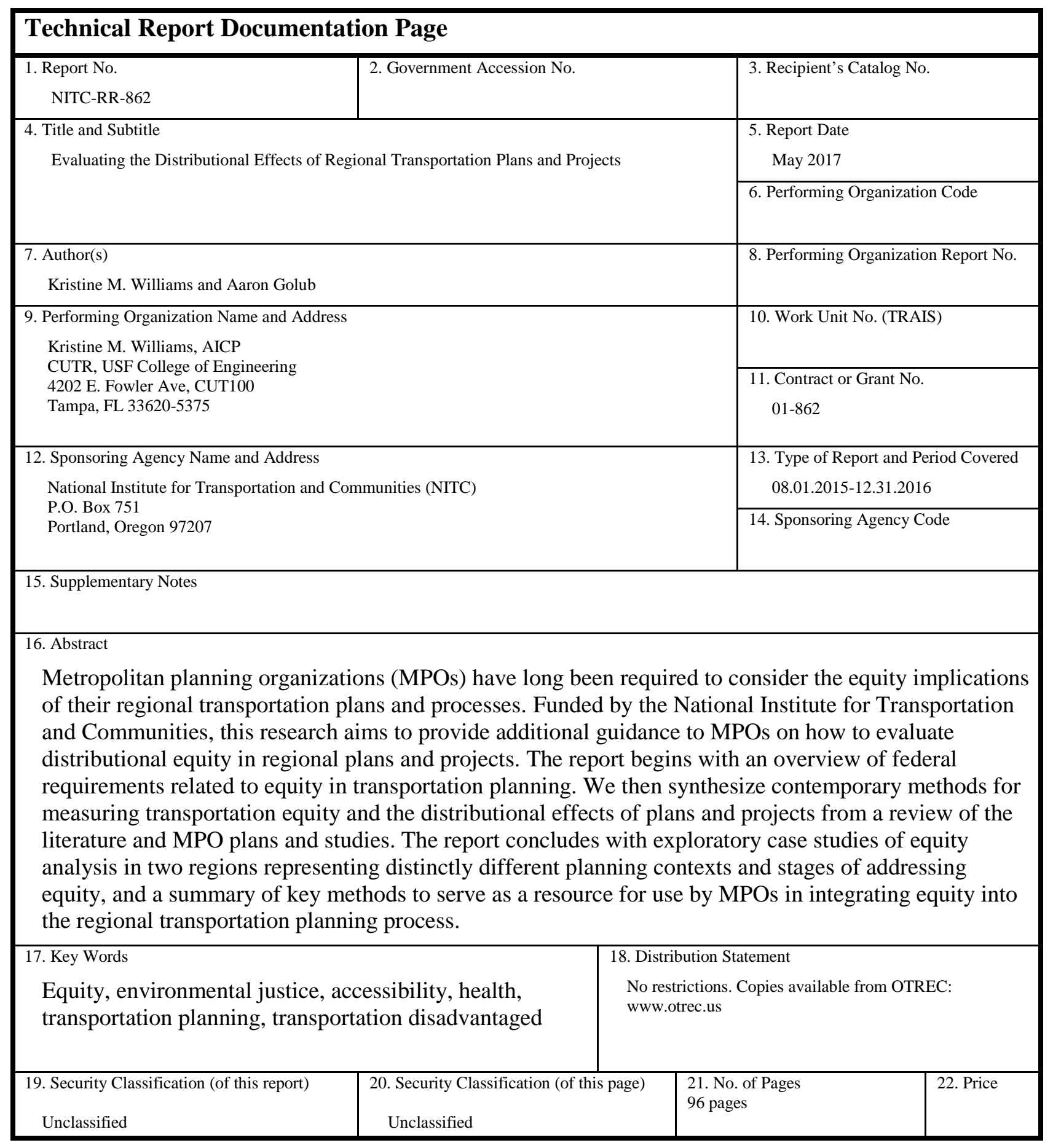




\section{ACKNOWLEDGEMENTS}

This project was funded by the National Institute for Transportation and Communities (NITC). The report was authored by co-Principal Investigators Kristine M. Williams, AICP, University of South Florida (CUTR) and Aaron Golub, PhD, Portland State University. CUTR researchers responsible for performing the Hillsborough case study GIS analyses include Senior Research Associate Martin Catala and PhD candidate Elzbieta Bialkowska-Jelinska. The authors thank all those who participated in the case studies for their valuable insights and many contributions to the report. These individuals are Michele Ogilvie and Wade Reynolds, AICP, Hillsborough Metropolitan Planning Organization (MPO) in Tampa, FL, and Grace Cho, Metro, the MPO for Portland, OR.

We also thank the following for their helpful responses to our queries during the project. Doug Johnson, the Principal Transportation Planner for Land Use and Social Equity, and Vikrant Sood, Senior Planner, both of the Metropolitan Transportation Commission and Bay Area (San Francisco, CA); Richard Marcantonio, the managing attorney for Public Advocates, Inc., specializing in civil rights advocacy and transportation equity; and Alex Karner, the assistant professor for the School of City and Regional Planning at the Georgia Institute of Technology, an equity analysis specialist.

Finally, the authors acknowledge the efforts of Graduate Research Assistants Joshua Barber, Austin Gibble, Monica Martin, and Katherine Selin, for their extensive efforts in reviewing literature and MPO long-range transportation plans and studies, assisting with case study documentation, and cataloguing practices for inclusion in the final report.

\section{DISCLAIMER}

The contents of this report reflect the views of the authors, who are solely responsible for the facts and the accuracy of the material and information presented herein. This document is disseminated under the sponsorship of the U.S. Department of Transportation University Transportation Centers Program and Portland State University in the interest of information exchange. The U.S. Government and Portland State University assume no liability for the contents or use thereof. The contents do not necessarily reflect the official views of the U.S. Government and Portland State University. This report does not constitute a standard, specification, or regulation. 



\section{TABLE OF CONTENTS}

EXECUTIVE SUMMARY .................................................................................................. 1

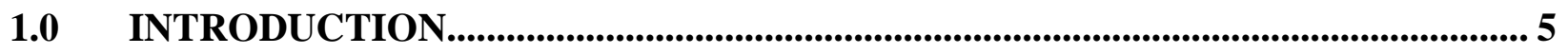

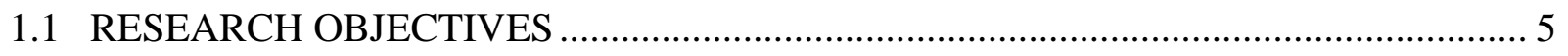

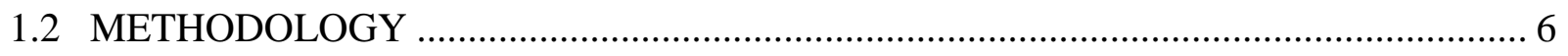

1.3 EQUITY REQUIREMENTS AND GUIDANCE ....................................................... 7

1.3.1 U.S. Department of Transportation Regulations Directing Social Equity

Assessments ................................................................................................................. 9

1.3.2 Title VI Guidance for Addressing Social Equity in Regional Transportation Plans 10

1.3.3 Executive Order 12898 and Application to Social Equity Assessments .................. 10

1.3.4 Interpretations and Recent Updates of Title VI and EJ Guidance ............................ 10

1.4 KEY FINDINGS FROM THE LITERATURE ............................................................. 12

1.4.1 Defining and Locating Communities of Concern (COCs) ........................................ 13

1.4.2 Involving Communities of Concern.......................................................................... 15

1.4.3 Accessibility and Transportation Options................................................................... 16

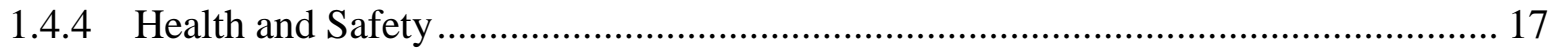

1.4.5 Transportation and Housing Affordability.............................................................. 17

1.4.6 Distributional Equity.................................................................................... 18

1.5 REVIEW OF MPO EQUITY PLANNING PRACTICES ................................................ 20

1.5.1 Defining and Locating Communities of Concern.................................................... 20

1.5.2 Involving Communities of Concern..................................................................... 23

1.5.3 Evaluating Accessibility and Transportation Options ……………………............... 24

1.5.4 Examining Health and Safety Impacts............................................................... 27

1.5.5 Transportation and Housing Affordability............................................................. 28

1.5.6 Determining Distributional Equity of Investments................................................. 30

1.5.7 Performance Measurement ..................................................................................... 32

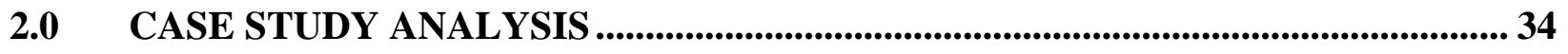

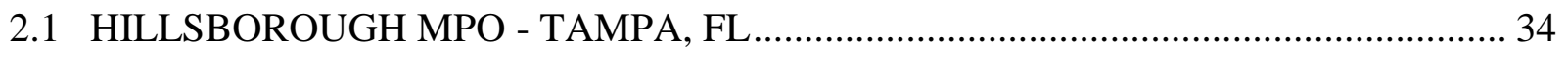

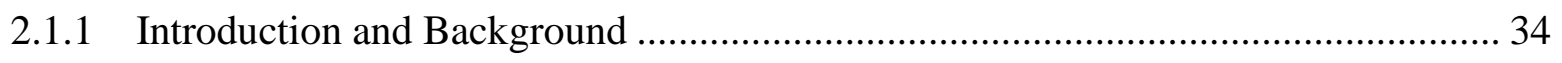

2.1.1.1 Planning Context ........................................................................................ 34

2.1.1.2 Methods to Involve Communities of Concern ...................................................... 36 


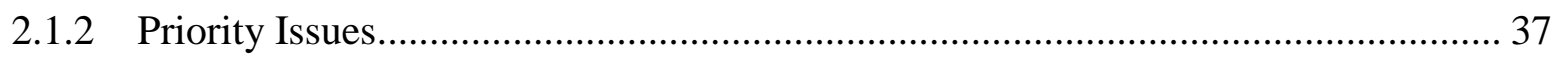

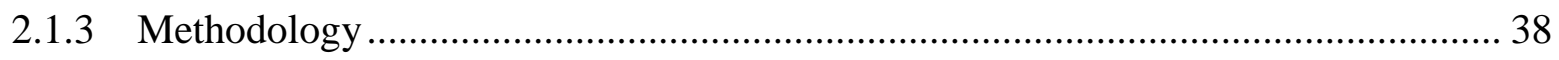

2.1.3.1 Identifying Communities of Concern ............................................................... 38

2.1.3.2 Identifying Essential Destinations ..................................................................... 40

2.1.3.3 Exploring Accessibility ................................................................................... 42

2.1.3.4 Housing + Transportation Affordability.............................................................. 46

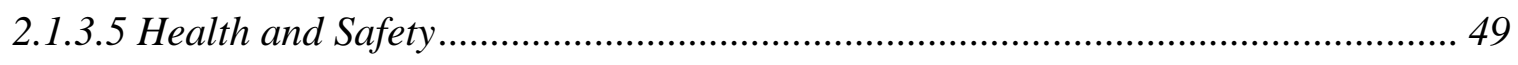

2.1.3.6 Distributional Equity of Investments .............................................................. 51

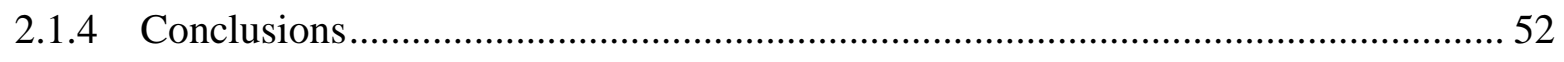

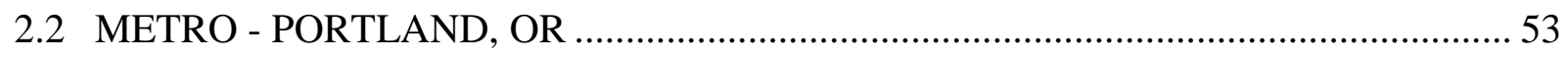

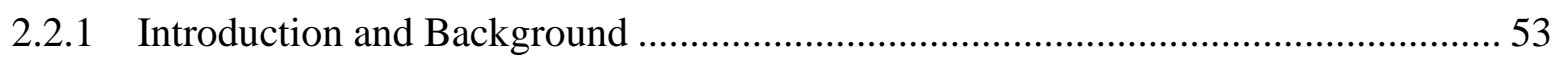

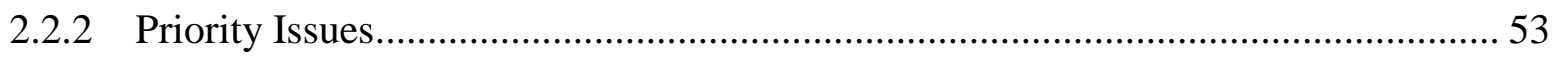

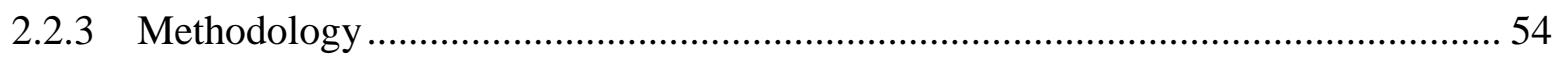

2.2.3.1 Identifying Historically Marginalized Communities ............................................. 54

2.2.3.2 Public Participation...................................................................................... 56

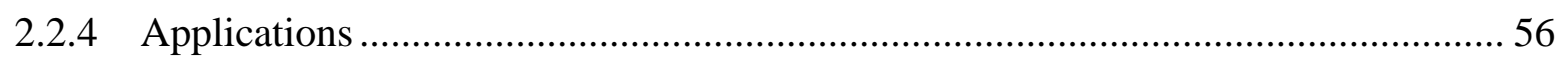

2.2.4.1 Proposed Equity Measures and Methods …………………............................. 56

2.2.4.2 Methods of Analysis ....................................................................................... 58

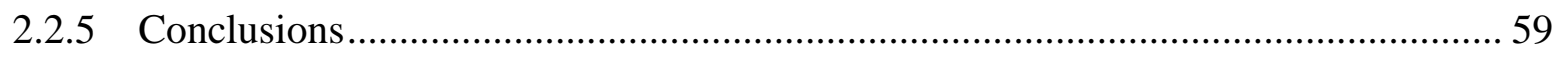

3.0 OVERVIEW OF KEY METHODS AND MEASURES ............................................60

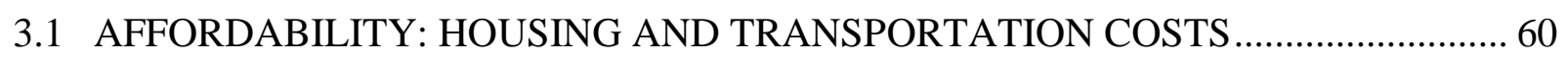

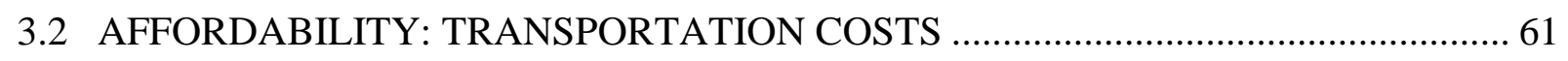

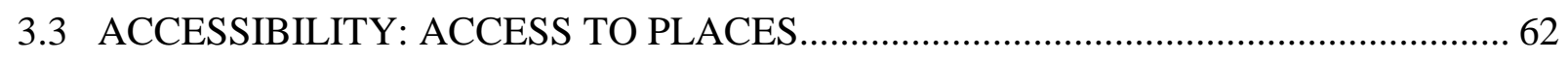

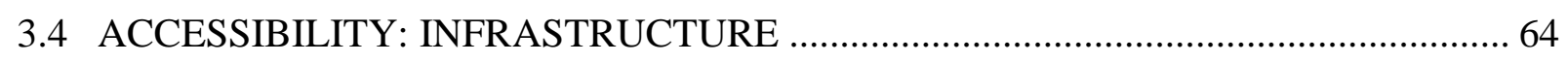

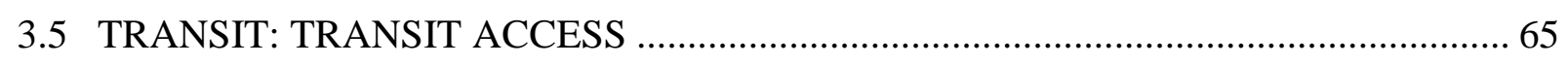

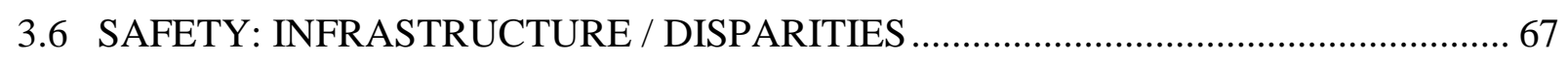

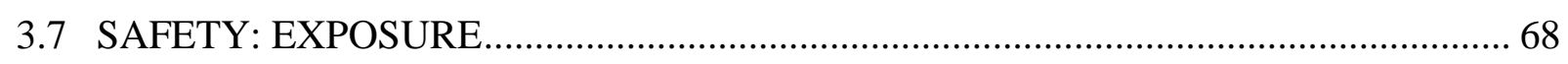

3.8 PUBLIC HEALTH: ENVIRONMENTAL AND HEALTH IMPACTS.............................. 69

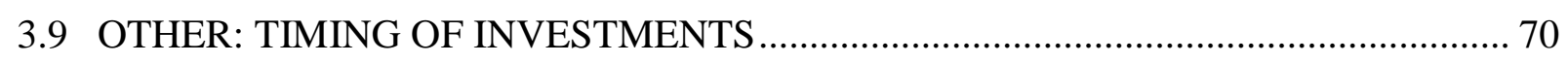

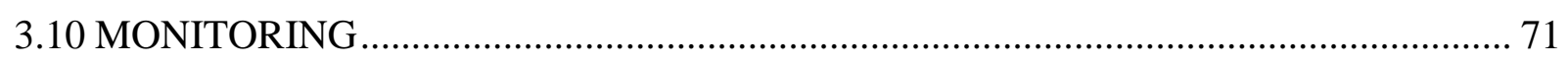

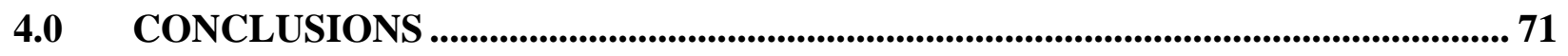

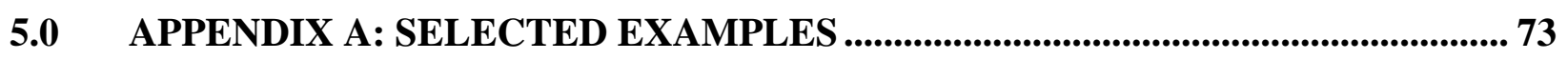

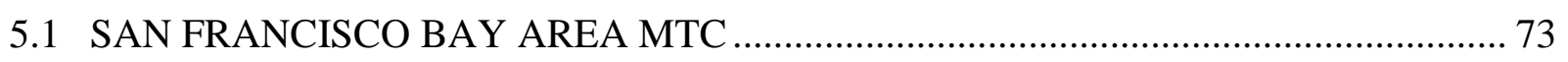

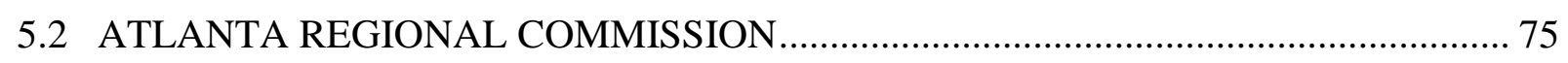


5.3 POLK TRANSPORTATION PLANNING ORGANIZATION (TPO) …………….......... 77

5.4 SAN DIEGO ASSOCIATION OF GOVERNMENTS (SANDAG) ................................. 79

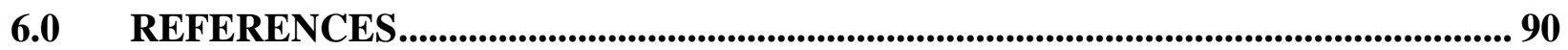

\section{LIST OF TABLES}

Table 1: Federal Regulations, Laws, and Guidance for Equity in Regional Transportation Plans 7

Table 2: Required and Encountered Title VI and Environmental Justice Components of MPO

Documents

Table 3: MPO Methods for Identifying Communities of Concern 21

Table 4: Indices Used to Identify Communities of Concern 22

Table 5. Methods used by MPOs to Involve Communities of Concern 23

Table 6. MPO Measures of Accessibility and Transportation Options 24

Table 7: Examples of MPO Accessibility Analysis Methodologies 25

Table 8: NJTPA Bicycle and Pedestrian Accessibility Methodology 26

Table 9. MPO Health and Safety Analysis 27

Table 10: Block Groups by Level of Cyclist Safety 28

Table 11. Housing plus Transportation Cost Affordability 29

Table 12. Distributional Equity of Investments 31

Table 13: MPO Equity-Related Indicators and Benchmarks 32

Table 14. Example Equity and Community Engagement Performance Measures 33

Table 15: Identifying Communities of Concern 38

Table 16: Identifying Essential Destinations 41

Table 17: Accessibility Metrics for Consideration by Hillsborough MPO 42

Table 18: Affordability Measures and Methodology 47

Table 19: Bicycle and Pedestrian Safety Measures and Methodology 50

Table 20: Distributional Equity of Investments Measure and Methodology 52

Table 21: Metro Tier II Thresholds for Identifying Historically Marginalized Communities 55

Table 22: Proposed Equity Measures for METRO 2018 Regional Transportation Plan 57

\section{LIST OF FIGURES}

Figure 1: Population Weighting Method in City of Fresno ........................................................... 14

Figure 2. Transportation investments in equitable target areas (ETAs). ......................................... 31 
Figure 3. Hillsborough communities of concern. ................................................................ 40

Figure 4: Essential destinations in Hillsborough County. ..................................................... 41

Figure 5: Communities of concern with low pedestrian accessibility to essential destinations... 43

Figure 6: Communities of concern with low bicycle accessibility to essential destinations........ 44

Figure 7: Areas with the least job accessibility within 45 minutes via transit........................... 45

Figure 8: Communities of concern with the least job accessibility within 45 minutes via transit. 46

Figure 9: Housing plus transportation affordability in Hillsborough County............................. 48

Figure 10: Average transportation costs of communities of concern in Hillsborough County.... 49

Figure 11: Communities of concern with high pedestrian crashes per capita. ........................... 50

Figure 12: Communities of concern with high bicycle crashes per capita. ................................ 51

Figure 13. Results from a walkability analysis in San Diego............................................... 82

Figure 14. Available transportation infrastructure and support in San Diego........................... 84

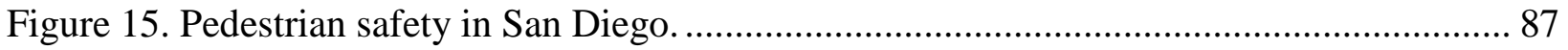




\section{EXECUTIVE SUMMARY}

\section{Introduction and Objectives}

Metropolitan planning organizations (MPOs) have long been required to consider the equity implications of their regional transportation plans and processes. Federal law and guidance relative to Title VI and Environmental Justice requires MPOs to engage historically disadvantaged communities in the planning process, to address the equity effects of MPO plans and projects, and to systematically incorporate these analyses into their planning processes. Despite widespread evidence that MPOs are making efforts to address equity goals, the role of equity analysis in shaping long-range transportation plans and project decisions is often unclear and undefined. More guidance is needed on best practice methods and performance measures for addressing equity in a regional transportation planning context.

Funded by the National Institute for Transportation and Communities, this research aims to provide additional guidance to MPOs on how to evaluate distributional equity in regional plans and projects. The project evolved as a partnership between Portland State University and the University of South Florida and their respective MPOs. The team used the varied interests of the Portland Metro regional government and the Hillsborough MPO to create an analysis of equity metrics and planning recommendations at different stages in the planning process. Both teams were able to engage directly with their regional governments and use those experiences to inform this research project, while also generating valuable insights for the regional planning processes.

The specific research objectives of this project include the following:

1. Identify, collect and understand current practices for measuring transportation equity and the distributional effects of regional transportation plans and projects.

2. Inform current or future public engagement efforts of the Portland MPO equity analysis and the Hillsborough County transportation disadvantaged service program.

3. Synthesize methods for addressing key transportation equity issues of importance to metropolitan areas, including improved or new analyses, and related techniques and data collection methods.

4. Assist two metropolitan planning organizations - Hillsborough County in Tampa, FL, and Portland, OR - in further developing and applying methods of distributional and accessibility analysis in their regional planning efforts.

5. Document and disseminate these findings.

\section{Methodology}

The research began with an assessment of national research on the topic of equity in transportation planning. MPO planning documents and current literature were reviewed to determine the range of transportation equity analysis strategies employed nationally. The comparative review addressed how MPOs defined communities of concern and located them spatially; what strategies were employed to engage them in the planning process; and metrics used to evaluate equity in relation to transportation policies, projects and expenditures. Publicly available documents were used to conduct the analysis. 


\section{Equity Requirements and Guidance}

MPOs are legally required and socially obligated to evaluate the distributional effects of long-range transportation planning and take steps to address the needs of, as well as mitigate adverse effects on, low-income communities, minority groups, older residents, those with limited English proficiency, and other historically marginalized stakeholders. These requirements are based on two streams of federal regulations: Title VI of the Civil Rights Act and the Environmental Justice Executive Order 12898. These regulations have been interpreted for transportation planning purposes at various points over the past four decades into a series of guidelines issued by U.S. Department of Transportation modal agencies.

Our report reviews some of the more significant points from these guidance documents, and emphasizes the following steps for integrating equity analysis into transportation planning:

- Developing community profiles for the planning area and maintaining a GIS database with the capability to analyze socioeconomic demographics, define target populations, and locate them spatially.

- Establishing an ongoing or concerted public involvement effort that is specially oriented toward achieving a better understanding of the needs and concerns of low-income and minority populations and other transportation-disadvantaged populations.

- Developing a system-level process for understanding the distributional effects of transportation investments on accessibility of these populations to jobs and services and on the availability of transportation alternatives in each region.

- Documenting the results for use in planning decision making. In particular, this should occur during development of the MPO long-range transportation plan (LRTP).

In addition, while we found recommendations to address the distribution of transportation benefits, what qualifies as fair distribution is open for interpretation. The academic literature points to two distributional approaches. One is a "proportionality approach," which examines whether communities of concern receive benefits in proportion to other populations. Although seemingly logical, this approach fails to compensate for what may be a history of underinvestment. This leads to a second approach, called "restorative," in which transportation investments are distributed in a manner that favors underserved communities and reduces inequalities over time. Some argue that a sustained effort over several decades will be needed to rectify the consequences of past actions and ensure investment actions produce the desired benefits in the future.

Other issues in current practice relate to the use of traditional long-range planning methods. Some argue that MPO equity analyses should focus on current needs rather than longrange forecasts, as migration patterns are rarely accurately predicted. This perspective advocates the following approach to achieving greater equity in regional planning:

- Using transportation funds to invest in needs expressed by historically disadvantaged communities;

- Allowing the community to make final decisions on proposed projects for their areas;

- Recognizing that the funds available today should be used for the needs of today rather than the predicted future; and

- Tailoring performance metrics and targets to equity objectives and tracking progress. 


\section{Evaluation of MPO Equity Planning Practices}

Our report documents some of the major steps involved in addressing equity in transportation planning. We review contemporary practices in the following areas:

- Defining and Locating Communities of Concern

- Involving Communities of Concern

- Determining Distributional Equity of Investments

- Evaluating Accessibility and Transportation Options

- Examining Health and Safety Impacts

- Housing and Transportation Affordability

- Performance Indicators for Equity

For each, we highlight contemporary practices from a review of MPOs' plans and documents throughout the country. We present typical measures and data sources used for these equity analyses.

\section{Case Studies}

Building upon the findings of the literature and current practice survey, the CUTR (University of South Florida) and Portland State University research teams proceeded with case study applications with their respective MPO partners - Hillsborough MPO (Tampa, FL) and Metro (Portland, OR). Our project work attempted to engage with these two planning processes, and support their research needs while also learning from them. The Florida research team engaged with Hillsborough MPO staff on methods for identifying communities of concern and issues of transit, pedestrian and bicycle accessibility to essential destinations; housing and transportation costs; and safety. The Oregon research team engaged with the Metro planning process by supporting staff research needs as they developed the equity analysis measures for the long-range plan update. In that capacity, the research team developed a national assessment of contemporary equity measures and assisted staff in evaluating those measures for their regional planning needs. The research involved in both of these case studies is presented in our report, including equity measures developed and other mapping and analysis performed. 



\subsection{INTRODUCTION}

Metropolitan planning organizations (MPOs) have long been required to consider the equity implications of their regional transportation plans and processes. Federal law and guidance relative to Title VI and Environmental Justice requires MPOs to engage historically disadvantaged communities in the planning process, to address the distribution of burdens and benefits created by MPO plans and projects, and to systematically incorporate these analyses and concerns into their planning processes. Yet federal guidance falls short of providing specific measures or standards to assess the distribution of benefits and burdens from projects or plans.

The lack of specific guidance on methods for evaluating distributional equity in regional transportation planning has led to a patchwork of approaches. Despite widespread evidence that MPOs are working toward equity goals, the role of equity analysis in shaping long-range transportation plans and project decisions also tends to be haphazard or undefined. MPOs would benefit from additional guidance on methods and performance measures for systematically addressing equity in a regional transportation planning context.

Funded by the National Institute for Transportation and Communities, this research aims to provide such guidance. The project evolved as a partnership between Portland State University and the University of South Florida and their respective MPOs. The team used the varied interests of the Portland (OR) Metro regional government and the Hillsborough MPO, which covers the Tampa, FL urbanized area, to create an analysis of equity metrics and planning recommendations that would be practical and implementable for MPOs in different planning contexts. Researchers then worked with their respective MPOs, each at different stages in the planning process, to provide technical support and/or to help inform public dialogue.

The final report catalogues the various methods in use by MPOs to evaluate equity in planning, including emerging methods, data sources and processes for distributional and accessibility analyses. Example performance measures are also identified for use in evaluating and monitoring plan impacts and guiding project priorities. Selected methods and measures are tested in two diverse metropolitan areas (Hillsborough County/Tampa, FL, and Portland, OR) for further insight. The report concludes with a synthesis of methods and measures and a brief discussion of contemporary directions for advancing regional transportation equity in the context of metropolitan transportation planning.

\subsection{RESEARCH OBJECTIVES}

Specific research objectives include the following:

1. Identify, collect and understand current practices for measuring transportation equity and the distributional effects of regional transportation plans and projects.

2. Inform current or future public engagement efforts of the Portland MPO equity analysis and the Hillsborough County transportation disadvantaged service program.

3. Synthesize methods for addressing key transportation equity issues of importance to metropolitan areas, including improved or new analyses, and related techniques and data collection methods. 
4. Assist two metropolitan planning organizations - Hillsborough County in Tampa, FL, and Portland, OR - in further developing and applying methods of distributional and accessibility analysis in their regional planning efforts.

5. Document and disseminate these findings.

\subsection{METHODOLOGY}

The research team used quantitative and qualitative methods to achieve its research objectives. These methods included a comprehensive review of the literature, as well as a comparative review of MPO plans to document national best practices in equity analysis. We then documented a variety of measures, data sources and analysis techniques, and explore how these measures could be applied in the regional planning process through the use of geographic information systems (GIS), travel demand models and stakeholder engagement.

The research began with an assessment of national research on the topic of equity in transportation planning. MPO planning documents and current literature were reviewed to determine the range of transportation equity analysis strategies employed nationally. Methods used by large MPOs were documented, as well as notable practices of smaller MPOs in various parts of the country. The comparative review addressed how MPOs defined communities of concern under Title VI and other guidance; how they located them spatially; what strategies were employed to engage these communities in the planning process; and metrics used to evaluate equity in relation to transportation policies, projects and expenditures. Publicly available documents were used to conduct the analysis.

New methods and data sources for equity analysis were then developed that consider the needs of two distinctly different metropolitan planning areas: 1) Hillsborough County is a relatively low-density, sprawling, auto-dependent area with limited public transportation; and 2) Portland is a higher-density, compact urban area with a variety of travel options and a strong urban growth management system. The two MPOs also differ in their approach to addressing transportation equity in previous planning and public engagement activities. Portland has a formal working group dedicated to measuring equity as a key performance measure in the regional plan, following up from efforts in previous plans, while Hillsborough County is exploring how to more systematically evaluate equity in the regional planning process.

Both MPOs are in the process of updating their long-range transportation plans and related plans, such as transportation-disadvantaged service plans, which aim to improve and coordinate transportation resources and services for elderly, disabled, or economically disadvantaged people. The specific priorities of each region vary and were identified based upon MPO staff recommendations, a review of current practices, and feedback from communities of concern and other identified stakeholders. Dimensions of equity of interest to the MPOs include: health and safety; affordability (e.g., combined transportation and housing costs); accessibility to employment and essential services; the potential for transportation investments to create pressures for displacement; and distributional equity of transportation investments.

Given the planning timeline of both MPOs, these analyses either served as recommendations for current or future plan or project evaluation. The new methods or data collection needs were tested and subsequently refined, and provided to each agency for their consideration in ongoing and/or future evaluation and data collection practices. Efforts were also made to assist MPO staff and other interested parties in the understanding and use of selected transportation equity measures. 


\subsection{EQUITY REQUIREMENTS AND GUIDANCE}

MPOs are legally required and socially obligated to evaluate the distributional effects of long-range transportation planning and take steps to mitigate adverse effects on low-income communities, minority groups, older residents, those with limited English proficiency, and other historically marginalized stakeholders. These requirements are based on two streams of federal regulations: Title VI of the Civil Rights Act and the Environmental Justice Executive Order 12898. These regulations have been interpreted for transportation planning purposes at various points over the past four decades and are listed in Table 1. Further detail is given below about the regulations and their interpretation for regional planning.

Table 1: Federal Regulations, Laws, and Guidance for Equity in Regional Transportation Plans

\begin{tabular}{|c|c|c|}
\hline & Title VI Lineage & EJ Lineage \\
\hline 1960s & $\begin{array}{l}\text { Title VI of the Civil Rights Act of 1964, } 42 \\
\text { U.S.C. 2000(d) et seq. (July 2, 1964) }\end{array}$ & \\
\hline 1970s & $\begin{array}{l}\text { Department of Transportation of the United } \\
\text { States (DOT). (1970) Nondiscrimination in } \\
\text { Federally-Assisted Programs of The Department } \\
\text { of Transportation--Effectuation of Title VI of the } \\
\text { Civil Rights Act of 1964. U.S. Code of Federal } \\
\text { Regulations. } 49 \text { CFR Part 21. (June 18, 1970) }\end{array}$ & \\
\hline 1980s & $\begin{array}{l}\text { Federal Transit Administration of the United } \\
\text { States (FTA). (1988) Circular } 4702.1 \text { “Title VI } \\
\text { and Title-VI Dependent Guidelines for Federal } \\
\text { Transit Administration Recipients” (May 26, } \\
\text { 1988) }\end{array}$ & \\
\hline \multirow[t]{3}{*}{ 1990s } & $\begin{array}{l}\text { Federal Highway Administration and Federal } \\
\text { Transit Administration of the United States } \\
\text { (FHWA and FTA). (1999) Memorandum on } \\
\text { Implementing Title VI Requirements in } \\
\text { Metropolitan and Statewide Planning (Oct 7, } \\
\text { 1999) }\end{array}$ & $\begin{array}{l}\text { Executive Order 12898, entitled "Federal } \\
\text { Actions to Address Environmental Justice in } \\
\text { Minority Populations and Low-Income } \\
\text { Populations" (Feb 11, 1994). }\end{array}$ \\
\hline & & $\begin{array}{l}\text { Department of Transportation of the United } \\
\text { States (DOT). (1997) Order } 5610.2 \text { Department } \\
\text { of Transportation Actions to Address } \\
\text { Environmental Justice in Minority Populations } \\
\text { and Low-Income Populations (April 15, 1997). }\end{array}$ \\
\hline & & $\begin{array}{l}\text { Federal Highway Administration of the United } \\
\text { States (FHWA). (1998) Order 6640.23 FHWA } \\
\text { Actions to Address Environmental Justice in } \\
\text { Minority Populations and Low-Income } \\
\text { Populations (Dec 2, 1998). }\end{array}$ \\
\hline
\end{tabular}




\begin{tabular}{|c|c|c|}
\hline $2000 \mathrm{~s}$ & $\begin{array}{l}\text { Federal Transit Administration of the United } \\
\text { States (FTA). (2007) Circular 4702.1(a) “Title VI } \\
\text { and Title-VI Dependent Guidelines for Federal } \\
\text { Transit Administration Recipients” (May 13, } \\
\text { 2007) }\end{array}$ & \\
\hline \multirow[t]{3}{*}{ 2010s } & $\begin{array}{l}\text { Federal Transit Administration of the United } \\
\text { States (FTA). (2012) Circular 4702.1 (b) “Title } \\
\text { VI Program Guidelines for Federal Transit } \\
\text { Administration Recipients” (Oct 1, 2012) }\end{array}$ & $\begin{array}{l}\text { Department of Transportation of the United } \\
\text { States (DOT). (2012) Order 5610.2(a) } \\
\text { Department of Transportation Actions to } \\
\text { Address Environmental Justice in Minority } \\
\text { Populations and Low-Income Populations (May } \\
\text { 2, 2012). }\end{array}$ \\
\hline & & $\begin{array}{l}\text { Federal Highway Administration of the United } \\
\text { States (FHWA). (2012) Order 6640.23(a) } \\
\text { FHWA Actions to Address Environmental } \\
\text { Justice in Minority Populations and Low-Income } \\
\text { Populations (June 14, 2012). }\end{array}$ \\
\hline & & $\begin{array}{l}\text { Federal Transit Administration of the United } \\
\text { States (FTA). (2012) Circular } 4703.1 \\
\text { Environmental Justice Policy Guidance for } \\
\text { Federal Transit Administration Recipients (Aug } \\
\text { 15, 2012). }\end{array}$ \\
\hline
\end{tabular}

Federal statutes and subsequent regulations from transportation agencies addressing social equity in regional transportation planning rest on Title VI of the Civil Rights Act of 1964(42 CFR 2000(d) et seq.), which states:

No person in the United States shall, on the ground of race, color, or national origin, be excluded from participation in, be denied the benefits of, or be subjected to discrimination under any program or activity receiving Federal financial assistance. (Sec 2000(d))

The regulation to apply and enforce the act in the transportation realm is found in the Department of Transportation (DOT) (1970) regulation entitled Nondiscrimination in FederallyAssisted Programs of the Department of Transportation -- Effectuation of Title VI of the Civil Rights Act of 1964(49 CFR part 21). It interprets the core Title VI requirement for transportation as follows:

A recipient [of DOT assistance], in determining the types of services, financial aid, other benefits, or facilities which will be provided under any such program (...) may not (...) utilize criteria or methods of administration which have the effect of subjecting persons to discrimination... (Sec. 21.5(2)).

Since regional transportation planning affects the types and configurations of transportation services and facilities, it must meet the requirements of this regulation. Perhaps most relevant to regional transportation planning is this statement from the 1970 DOT regulation, 
which encourages taking affirmative steps to remove or overcome the effects of past discrimination in planning:

This part [of the DOT Title VI regulation] does not prohibit the consideration of race, color, or national origin if the purpose and effect are to remove or overcome the consequences of practices or impediments which have restricted the availability of, or participation in, the program or activity receiving Federal financial assistance, on the grounds of race, color, or national origin. Where prior discriminatory practice or usage tends ... to deny them the benefits of ... any program or activity to which this part applies, the applicant or recipient must take affirmative action to remove or overcome the effects of the prior discriminatory practice or usage. Even in the absence of prior discriminatory practice or usage, a recipient in administering a program or activity to which this part applies, is expected to take affirmative action to assure that no person is excluded from participation in or denied the benefits of the program or activity on the grounds of race, color, or national origin. (Sec. 21.5(b)(7))

\subsubsection{U.S. Department of Transportation Regulations Directing Social Equity Assessments}

Requirements pertaining to protecting civil rights in regional transportation plans are derived from the Civil Rights Act of 1964 (Title VI specifically). The requirement to meet Title VI is clearly noted in the Department of Transportation's Planning Assistance and Standards Subpart C: Metropolitan Transportation Planning and Programming (23 CFR 450), the main regulations governing regional transportation plans and transportation fund programming. These regulations include the requirement that the "metropolitan transportation planning process is being carried out in accordance with... Title VI of the Civil Rights Act of 1964, as amended (42 U.S.C. 2000d-1) and 49 CFR part 21.” (23 CFR 450.334 (a) (3))

Additionally, recent "Planning Emphasis Areas" memoranda (FHWA, 2015b, 2016) from the former U.S. Secretary of Transportation Anthony Foxx to MPOs and state transportation agencies have highlighted the importance of equity among the various competing demands for priorities in regional planning. For example, the 2016 memorandum includes, in a section titled "Ladders of Opportunity," the following language:

We encourage State DOTs, MPOs, and providers of public transportation, as part of the transportation planning process, to identify transportation connectivity gaps in accessing essential services. Essential services include employment, health care, schools/education, and recreation. ...tasks include developing and implementing analytical methods to identify gaps in the connectivity of the transportation system and developing infrastructure and operational solutions that provide the public, especially the traditionally underserved populations, with adequate access to essential services. Other effective work tasks could include: evaluating the effectiveness of public participation plans for engaging transportation disadvantaged communities in the transportation decision making process; updating the Section 5310 Coordinated Human Service Public Transportation Plans; assessing the safety and condition of pedestrian and bicycle facilities; and evaluating compliance with Americans with Disabilities Act, particularly around schools, concentrations of disadvantaged populations, social services, medical, and transit facilities. (p. 2) 
The Ladders of Opportunity Program is intended to repair and replace infrastructure that expands economic opportunity and socioeconomic mobility (USDOT, 2016b). In 2016, the USDOT announced its National Transit Map Initiative, which will display stops, routes and schedules for all participating transit agencies and be a useful tool for supporting "ladders of opportunity” (USDOT, 2016a). The next sections present a subset of federal guidance that directly addresses the regional transportation plan.

\subsubsection{Title VI Guidance for Addressing Social Equity in Regional Transportation Plans}

The most relevant federal guidance for MPOs implementing Title VI in regional plans is the "Memorandum on Implementing Title VI Requirements in Metropolitan and Statewide Planning” released jointly by the FHWA and the Federal Transit Administration (FTA) in 1999. The memorandum contains a short introduction with two attachments outlining standards for assessing Title VI compliance. The standards are presented as a series of questions used to evaluate the quality of Title VI compliance in regards to regional transportation plan analysis. Some questions relate to public involvement and others to the analysis and contents of the regional transportation plan. Table 1 illustrates required and frequently encountered Title VI and environmental justice components for MPO plans and products.

\subsubsection{Executive Order 12898 and Application to Social Equity Assessments}

To recognize and address environmental injustices often intertwined with civil rights, including Title VI infringements, President Clinton signed Executive Order 12898 Federal Actions to Address Environmental Justice in Minority Populations and Low-Income Population (herein EO 12898) in 1994. The order directed federal agencies to identify and address the impacts of their actions on EJ communities, develop a strategy for implementing EJ, and added income as a dimension of protection from unequal treatment. The EO's implementation in the various federal transportation agencies has important implications for regional transportation planning.

EO 12898 tends to focus on understanding and addressing unequal burdens in communities near transportation facilities; it has less direct relevance to long-range regional transportation plans. Still, there is relevant language found throughout the implementing guidance from DOT modal agencies concerning incorporating environmental justice concerns into regional transportation planning processes.

\subsubsection{Interpretations and Recent Updates of Title VI and EJ Guidance}

Two recent updates have further clarified MPO responsibilities in relation to equity and environmental justice (EJ). In 2012, the U.S. Department of Transportation (USDOT) issued an update to Departmental Order 5610.2(a) “Actions to Address Environmental Justice in Minority Populations and Low-Income Populations” (USDOT, 2012a). The update reaffirms the USDOT's commitment to environmental justice; clarifies aspects of the 1994 Executive Order (e.g., the definitions of "minority" populations); clarifies distinctions between Title VI analysis and EJ analysis as part of the NEPA review process; and asserts the importance of EJ in early planning activities (USDOT, 2012a). 
Rules for Title VI in public transportation were also updated in 2012 and were included in Federal Highway Administration Order 6640.23A (FHWA, 2012) and Federal Transit Administration Circular 4703.1 (FTA, 2012). These rules provide further guidance for implementing Title VI in planning. The FTA circular defines the benefits that shall be considered, such as increased transportation options, enhanced connectivity, improved air quality, increased property values, expanded employment opportunities, and reductions in travel time (FTA, 2012). It also requires agencies to address headways, vehicle loads, on-time performance, service availability, amenities and average fare payment (Martens \& Golub, 2014a).

While the overall goals of environmental justice have remained constant, the 2012 updates laid out two primary responsibilities for MPOs and other agencies receiving federal funds in regards to environmental justice. One is to ensure equitable access to information. It is stated in the USDOT order that (USDOT, 2012a, pg. 6-7):

"Planning and programming activities for policies, programs, and activities that have the potential to have a disproportionately high and adverse effect on human health or the environment shall include explicit consideration of the effects on minority and lowincome populations. Procedures shall be established or expanded, as necessary, to provide meaningful opportunities for public involvement by members of minority population and low-income populations during the planning and development of programs, policies, and activities...Steps shall be taken to provide the public, including members of minority and low-income populations, access to public information concerning the human health or environmental impacts of programs, policies, and activities, including information that will address the concerns of minority and lowincome populations regarding the health and environmental impacts of the proposed action.”

The second key responsibility of MPOs relates to data collection and analysis. MPOs must scrutinize demographic data to identify underserved communities and determine if they are burdened by any disproportionately high or adverse impacts (USDOT, 2012a).

Disproportionately high and adverse impacts are defined as an adverse effect that is predominately placed on a minority and/or a low-income population or an adverse effect that will be placed on a minority or low-income population and is substantially more severe than the adverse effect that would be placed on the non-minority and/or non-low-income population (USDOT, 2012a). Any impacts that are unavoidable must be mitigated or minimized (USDOT, 2012a; FDOT, 2015).

To carry out such efforts, MPOs and agencies are advised to "use all reasonable and available means at their disposal to better understand the demographics and needs of the communities within their areas” (FDOT, 2015, p. 13). For example, developing a Community Characteristics Inventory is one way to improve the ability of MPOs to identify underserved communities and evaluate distributional effects (FDOT, 2015). Additionally, MPOs can review their environmental justice strategies for effectiveness each year, as well as provide information and technical assistance to partner agencies. 


\subsection{KEY FINDINGS FROM THE LITERATURE}

A review of the literature offered several key findings and recommendations for better integrating equity considerations into the MPO transportation planning process. Table 2 identifies required and frequently encountered Title VI and EJ components of MPO planning documents. Required components are considered the minimum necessary to meet federal guidelines. Equity components that are frequently encountered illustrate typical ways that MPOs address or go beyond the minimum federal guidelines.

\section{Table 2: Required and Encountered Title VI and Environmental Justice Components of MPO Documents}

\begin{tabular}{|c|c|c|}
\hline Document Name & Required Components & Frequently Encountered Components \\
\hline $\begin{array}{l}\text { Unified Planning } \\
\text { Work Program }\end{array}$ & $\begin{array}{l}\text { - Certification of Disadvantaged Business } \\
\text { Enterprise and Equal Employment } \\
\text { Opportunity } \\
\text { - } \quad \text { Assurance of Compliance with Title VI }\end{array}$ & $\begin{array}{l}\text { - Tasks and funds for low-income and } \\
\text { minority population outreach and } \\
\text { involvement } \\
\text { - Tasks related to LEP populations } \\
\text { - Tasks and funds for necessary data } \\
\text { collection on low-income and } \\
\text { minority populations }\end{array}$ \\
\hline $\begin{array}{l}\text { Long-Range } \\
\text { Transportation } \\
\text { Plan }\end{array}$ & $\begin{array}{l}\text { - Identify and provide information to } \\
\text { "interested parties" about the Long-Range } \\
\text { Transportation Plan } \\
\text { - Assurance of Compliance with Title VI }\end{array}$ & $\begin{array}{l}\text { - Collection of data regarding low- } \\
\text { income and minority populations and } \\
\text { cultural resources } \\
\text { - Analysis of locations of low-income } \\
\text { and minority populations } \\
\text { - Goals and objectives for servicing } \\
\text { low-income and minority populations } \\
\text { Project selection criteria for the cost- } \\
\text { feasible plan that incorporate } \\
\text { projected impacts and benefits of } \\
\text { infrastructure on low-income and } \\
\text { minority populations } \\
\text { - Selection of cost-feasible projects that } \\
\text { minimize impacts on low-income and } \\
\text { minority populations and cultural } \\
\text { resources } \\
\text { Discussion of mitigation efforts } \\
\text { Execution and documentation of } \\
\text { public involvement efforts that target } \\
\text { low-income and minority populations } \\
\text { Preparation of a Coordinated Public } \\
\text { Transit-Human Services } \\
\text { Transportation Plan }\end{array}$ \\
\hline $\begin{array}{l}\text { Transportation } \\
\text { Improvement } \\
\text { Program (TIP) }\end{array}$ & $\begin{array}{l}\text { - Identify and provide "interested } \\
\text { parties" information about the TIP and } \\
\text { its projects } \\
\text { - Compliance with previously-adopted } \\
\text { Non-Discrimination Statement }\end{array}$ & $\begin{array}{l}\text { - Project selection criteria that } \\
\text { incorporate projected impacts and } \\
\text { benefits of infrastructure on low- } \\
\text { income and minority populations } \\
\text { - Public involvement efforts that target } \\
\text { low-income and minority populations }\end{array}$ \\
\hline $\begin{array}{l}\text { Public } \\
\text { Participation Plan }\end{array}$ & $\begin{array}{l}\text { - Compliance with previously-adopted } \\
\text { Non-Discrimination statement }\end{array}$ & $\begin{array}{l}\text { - } \quad \text { Description of LEP program } \\
\text { - } \quad \text { Identification of methods to involve } \\
\text { low-income and minority populations }\end{array}$ \\
\hline
\end{tabular}

Source: CUTR, 2011 pg. 6 
The academic literature and plans of select MPOs have also expanded equity analysis through more inclusive or detailed definitions of communities of concern with regard to equity, dynamic public involvement strategies, and the analysis of additional dimensions of equity. In line with this process, a Florida study (CUTR, 2011) noted that MPOs should focus future equity analysis efforts in the following areas:

- Developing community profiles for the planning area and maintaining a GIS database with the capability to analyze socioeconomic demographics, define target populations, and locate them spatially.

- Establishing an ongoing or concerted public involvement effort that is specially oriented toward achieving a better understanding of the needs and concerns of low-income, disabled, and minority populations.

- Developing a system-level process for understanding the distributional effects of transportation investments on accessibility of the target populations to jobs and services, and on the availability of transportation alternatives in each region.

- Documenting the results for use in planning decision making. In particular, this should occur during development of the MPO long-range transportation plan (LRTP).

\subsubsection{Defining and Locating Communities of Concern (COCs)}

Equity analysis begins with the identification of demographic characteristics of communities in a region and the spatial mapping process. This process can be challenging where communities of concern are dispersed across a region. Other issues include the multitude of interpretations for community, which can include, "legally-defined jurisdictions, statisticallydefined enumeration units, culturally-defined neighborhoods, and socially-defined affiliations" (Rowangould, Karner, and London, 2016).

A variety of indicators may be used to help target transportation disadvantaged and historically marginalized communities for equity analysis. Although race/ethnicity and income are central to EJ analysis, other indicators of disadvantage are recommended to ensure that the analysis does not overlook important needs (Rowangould, Karner, and London, 2016). Indicators used as a proxy for transportation disadvantage or to expand analysis beyond EJ communities include zero-vehicle households, limited English proficiency, single parent households, disability, and age (youth, elderly).

Once the indicators are selected, the analysis proceeds to the spatial mapping process. Rowangould et al. (2016) evaluate three distinct methodologies for spatially locating low income and minority communities for equity analysis: (1) a threshold-based approach that groups geographic areas using demographics, (2) a population-weighted approach that calculates weighted means of performance measures, and (3) community-based identification of target areas. They conclude that for EJ analysis in planning, it is best to use both a populationweighting method to first identify non-white, low income populations and then community-based identification of geographic area or population of concern, to better understand impacts of concern to the given community.

Threshold methods are most commonly used by MPOs for locating and mapping EJ and other target communities for equity analysis. Threshold methods can include: a) identifying equal shares of target versus non-target communities in an area, b) equal percent greater than the regional mean methods, and c) standard deviation greater than the regional mean methods. There 
is no guidance for selecting a threshold, and the threshold that is set can cause substantial variability in outcomes, particularly where COCs are dispersed across a region (Rowangould, Karner, and London, 2016). Therefore, the literature advises planners to corroborate the initial results through further specific analysis and community engagement. Population weighting methods, participatory mapping, or demographic analysis of service areas can be useful in this regard (Rowangould, Karner, and London, 2016).

Indices are sometimes used as an extension of the threshold method to combine multiple indicators of disadvantage into a single measure that identifies degrees or levels of disadvantage. While this method can be effective in identifying geographic areas of particular concern, it risks obscuring the needs of individual demographic groups (Rowangould, Karner, and London, 2016).

A population-weighting method of locating COCs does not identify discrete geographic areas, such as block groups, but rather the outcome for a particular group is calculated as the weighted mean of that demographic variable over all areas. An example map of this approach is provided in Figure 1: Population Weighting Method in City of Fresno This method represents actual locations of these communities and concentrations across the entire geographic area, rather than relative concentrations in relation to other communities within subunits of the study area. The methods used in this approach are more limited and less subjective than threshold methods (Rowangould, Karner, and London, 2016).

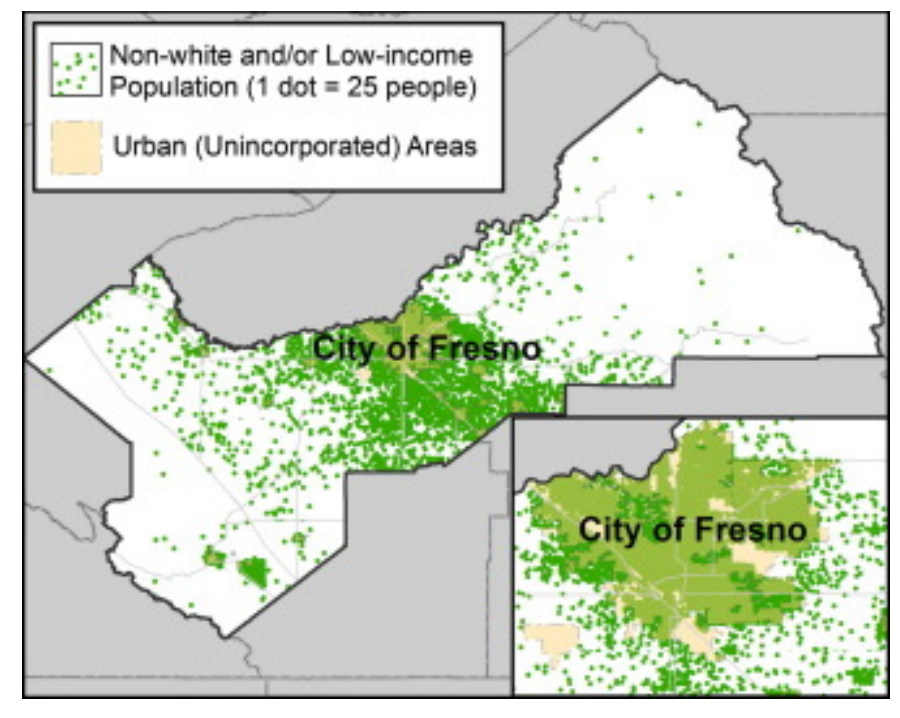

Figure 1: Population Weighting Method in City of Fresno

Source: Rowangould, Karner, and London, 2016

Another method for locating COCs is to involve a diverse group of community members and stakeholder organizations in self-identifying the locations of target communities. This approach can be part of the MPO public involvement process. While this method risks biased identification of COC areas, it can provide crucial insights as to the history and perception of neighborhoods by citizens and advocates. Given the functions and intentions of equity analysis, this approach can serve as a crucial part of involving COCs and empowering these communities (Rowangould, Karner, and London, 2016). 


\subsubsection{Involving Communities of Concern}

Public involvement is a core tenet of Title VI of the Civil Rights Act and Executive Order 12898. Federal guidance, including the 1999 Federal Highway Administration and Federal Transit Administration joint guidance, and the 2012 FTA Circular 4703.1, requires MPOs to identify how the needs of COCs are identified and considered in long-range planning efforts. A series of questions can be used to assess the effectiveness of an MPO's public involvement efforts with vulnerable communities (NITC, 2016):

- $\quad$ Does the public involvement process have an identified strategy for engaging minority and low-income populations in transportation decision making? What strategies, if any, have been implemented to reduce participation barriers for such populations? Has their effectiveness been evaluated? Has public involvement in the planning process been routinely evaluated as required by regulation? Have efforts been undertaken to improve performance, especially with regard to low-income and minority populations? Have organizations representing low-income and minority populations been consulted as part of this evaluation? Have their concerns been considered?

- What mechanisms are in place to ensure that issues and concerns raised by low-income and minority populations are appropriately considered in the decision making process? Is there evidence that these concerns have been appropriately considered? Has the metropolitan planning organization (MPO) or State DOT made funds available to local organizations that represent low-income and minority populations to enable their participation in planning processes?

An innovative method of engaging COCs in transportation equity has been developed and applied by Skeo Solutions, a Washington D.C. firm specializing in collaborative solutions to pressing issues in environmental stewardship, social equity and economic opportunity. The process involves Community Transportation Equity Dialogues (CTED) that are structured to cover three key issues:

1) Historic and current status of relationship between MPOs and impacted communities;

2) Community identification of transportation priority needs and gaps; and

3) Building community capacity to effectively engage in MPO planning and decisionmaking processes, and building MPO knowledge and capacity to adopt an equity approach to transportation planning.

Pre-community dialogue information is first gathered to ascertain current levels of engagement of impacted communities in MPO planning and decision-making processes, and the nature of past planning and public engagement activity. To make each CTED effective, extensive outreach is conducted to gather a broad, representative and authentic audience from the impacted communities. Traditional forms of MPO outreach are augmented with meeting notices distributed through ethnic radio and ethnic newspaper public service announcements (PSAs), outreach to local civic and faith-based organizations and neighborhood associations, as well as through local political representatives (council, state and congressional representatives). Where applicable, outreach notices and PSAs are translated into Spanish and distributed to radio and newspapers and civic groups that serve this population. 
The initial CTED focuses on the history of transportation planning and investment in the impacted community, current state of relationship between the impacted community and MPO, and community identification of transportation needs and gaps. The second CTED would focus on an equitable development approach to transportation planning. This second CTED would explore the concepts of transportation equity, civil rights applicability and equitable development. Two-way learning between MPO board members and staff and impacted community members is achieved through the dialogue and joint exercises. The second CTED focuses on developing an equity framework and guidance for expanded public engagement in MPO transportation planning and decision making.

The third and final CTED focuses on building the knowledge of impacted community residents about the structure and decision-making process of the MPO; the transportation project planning process and calendar; and growing their capacity to engage, participate in and serve on various MPO public decision-making structures. Where the impacted communities have significant non-English speaking populations, simultaneous translation is provided as well as translation of some materials.

The findings, results, outcomes and recommendations from each of the CTEDs are then captured in the narrative report prepared for each community to serve as a lasting reminder of the deliberations and to provide guidance for ongoing community engagement. Table 13, which appears in Section 1.5.7, provides examples of performance indicators that complement the approach. Further guidance on methods for involving communities of concern is provided in Section 1.5.2.

\subsubsection{Accessibility and Transportation Options}

A primary tenet of contemporary planning practice is a growing emphasis on accessibility to jobs and services as a critical performance measure. Manaugh, Badami and El-Geneidy (2014) note that to study equity within a region, the focus must be on determining levels of accessibility. Better connecting people to critical destinations and infrastructure in fiscally and environmentally sustainable ways, that are affordable to people of various incomes has become a key issue (Tomer et al., 2016).

The ability of low-income and minority populations to reach jobs, school, services and recreation has a profound impact on economic opportunity and quality of life. Accessibility is measured "to ensure that transportation systems are serving their intended purpose for all segments of the population, including EJ groups” (Martens, 2012; McCahill \& Ebeling, 2015, p.7). Several factors affect accessibility, including (Litman, 2016):

- Modal options: refers to the modes of transportation available to the user. Also includes the affordability, comfort, safety and convenience of those modes.

- Transport network connectivity: the density of paths and roadway connections and the directness of travel between destinations. Also includes connectivity between modes (i.e., bus stops and bike routes).

- Land use proximity: refers to the density and mix of land uses and the distance between destinations

Both model and non-model approaches are presented in the literature for evaluating the accessibility of targeted groups to essential destinations, along with a multitude of components or 
factors for analysis. Given the significant travel-cost differences between modes, accessibility is split, with transit, auto, biking, and walking accessibility to destinations evaluated separately. Accessibility can be measured at the individual/person-based level, or the location/place-based level. Travel-costs, an indicator of accessibility, can be measured based on travel time or distance.

Place-based accessibility is the most commonly used method, providing a relatively comprehensive view that can account for travel costs to specific destinations, land use characteristics, and the existing transportation network of a specific mode. For equity analysis, place-based measures should address the individual component factors through incorporating socio-economic characteristics (Boisjoly, 2017). In addition, as the essential component of accessibility is the ability to reach destinations, accessibility analyses should stratify essential destinations such as grocery stores, health facilities, government offices, and in particular, jobs and evaluate their accessibility for COCs separately to determine the extent of transportation disadvantage, as well as major gaps in the transportation system (Litman 2017; FTA 2014). Using these indicators, MPOs can compare the benefits and burdens of potential transportation investments or plans to inform decision-making. Section 3.3 and 3.4 provide an overview of key methods and measures for evaluating accessibility for equity.

\subsubsection{Health and Safety}

Given the well-established link between the urban form and the living environment on health and safety, examining the impacts of regional transportation plans on COCs in terms of these two components are important dimensions of equity (Kjellstrom, 2007). Examples of these impacts include but are not limited to exposure to crashes, exposure to emissions, and noise pollution. This topic also overlaps with accessibility in terms of availability of active transportation options as well as access to healthy food, healthcare and recreational opportunities.

Pedestrian and bicycle safety in particular is a growing concern for COCs. The report “Dangerous by Design 2014” (p. 13) released by the National Complete Streets Coalition (a program of Smart Growth America) noted that pedestrian fatalities disproportionately affect seniors, minorities and children. According to the report, people over age 65 make up $21 \%$ of pedestrian fatalities nationwide despite constituting just $12.6 \%$ of the population. African Americans have a $60 \%$ higher pedestrian fatality rate than Caucasians, and Hispanics have a $43 \%$ higher rate. Pedestrian fatalities are the third leading cause of death for children age 15 or younger. Further evidence shows a lack of adequate infrastructure for active transportation in many low-income and minority communities, as well as street designs neglecting users with special needs.

These statistics illustrate the importance of safety and health as it relates to COCs, and exemplify the need for evaluating the health and safety impacts of transportation plans and projects on disadvantaged communities. Sections 3.6 and 3.7 provide an overview of key measures for evaluating safety in terms of infrastructure and exposure, while section 3.8 provides key measures for evaluating the public health impacts of transportation plans and projects.

\subsubsection{Transportation and Housing Affordability}

Housing and transportation consume the largest percentage of income of American households. Location-efficient neighborhoods (e.g., compact, mixed-use, modal options, 
convenient access to jobs and services) tend to have lower transportation costs, but often lack affordable housing options. This can reduce accessibility of disadvantaged populations to jobs, services, healthy food and other important needs, and burden these populations with longer travel distances and higher transportation costs. An analysis of 28 metro regions in the U.S. found that lower income households typically have a higher cost burden for both housing and transportation, indicating the need for examining the implications of transportation plans and projects on transportation and housing affordability for disadvantaged communities (CNT, 2006).

A key resource for MPOs evaluating housing and transportation affordability is the online mapping tool developed by the Center for Neighborhood Technology (CNT), called the H+T Index, which provides interactive housing and transportation cost maps as well as other data at a neighborhood scale. The index evaluates neighborhood variables such as households per area, average block size, transit connectivity index, job density, average commute, income, household size, and workers per household. This tool further provides the data necessary for users to conduct their own $\mathrm{H}+\mathrm{T}$ analysis, allowing MPOs to easily evaluate affordability in their region, and ultimately incorporate it into their long-range planning processes (USDOT, 2015). The Hillsborough MPO case study provides a method for analyzing housing and transportation affordability in communities of concern using the CNT tool and data set. Sections 3.1 and 3.2 provide key methods and measures for evaluating housing and transportation affordability.

\subsubsection{Distributional Equity}

One of the foundational civil rights and environmental justice questions facing MPOs is whether transportation investments are distributed equitably. As distributional equity is typically not a stated goal in current practice, specific objectives and measures should be included to address this issue in the regional transportation plan (Martens, Golub \& Robinson, 2012). The following recommendations were offered for addressing the distributional effects of transportation investments (CUTR, 2011):

- Evaluate the impacts on relative accessibility of special-needs populations to jobs, services and other basic needs during alternatives analysis. Accessibility in large urban areas may be readily evaluated using travel demand models, activity-based models or GIS. Other ways to evaluate accessibility include sketch planning, documenting issues identified by the community, and professional judgment.

- Address the needs of all populations in the planning area. For transit-dependent populations, it is particularly important to address the availability of a range of alternatives to private ownership of automobiles, such as high-quality transit service, carshare/bikeshare programs, transportation-disadvantaged programs, and quality bicycle and pedestrian networks. Spatial analysis tools such as GIS are the primary method for evaluating these options.

- Consider resource distribution in relation to sociodemographic needs and whether equivalent priority is placed on providing high-quality service to low-income and minority communities.

- Consider whether adverse effects of transportation actions are being shifted onto lowincome and minority populations. This is particularly important for new highway 
alignments, transit station location decisions, or projects that would increase rail or roadway traffic through largely low-income or minority areas.

- Ensure that consideration of benefits and burdens are reflected in the long range transportation plan (LRTP) goals, objectives and measures of effectiveness. For example, MetroPlan Orlando included the following objective in its LRTP: "Identify the needs of low-income and minority populations, involve these populations in the planning process, and seek to equitably distribute the benefits and burdens of transportation investments among all populations.”

While transportation planning officials are mandated to address the distribution of transportation benefits, what qualifies as an equitable distribution is open for interpretation. Two general approaches have been discussed in the literature. One is a "proportionality approach," which examines whether communities of concern receive benefits and burdens in proportion to other populations, whether per capita or by another standard (Martens and Golub, 2014a, p. 25). Although seemingly logical, this approach fails to compensate for what may be a history of underinvestment.

This leads to a second approach, called "restorative," in which transportation investments are distributed in a manner that favors underserved communities and reduces inequalities over time. Some argue that a "sustained effort over several decades" will be needed to rectify the consequences of past actions, and ensure investment actions produce the desired benefits in the future. In addition, a clear goal is necessary to avoid assuming "the existing distributions are acceptable and are only in need of slight improvements” (Martens and Golub, 2014b, p. 19).

Other issues in current practice relate to the methods used. Marcantonio (2016) argues that MPO equity analysis should focus on current needs rather than long-range forecasts, as they rarely predict racial/ethnic migration patterns accurately. He further suggests that equity in regional transportation planning could best be achieved through adherence to the following four principles:

1) Using transportation funds to invest in needs expressed by the community;

2) Allowing the community to make final decisions on proposed projects for their areas;

3) Recognizing that the money available today should be used for the needs of today rather than the predicted future; and

4) Tailoring performance metrics and targets to equity objectives and tracking progress.

Marcantonio notes that substantial burdens to underserved communities, such as increased exposure to toxins, net losses in affordable housing and displacement, should be avoided, and that equity should be assessed in terms of whether priority needs are met and how well they are met to the underserved community - the benefits should be significant. Marcantonio suggests setting aside 25\% of any new revenue, compiled during the first four years of the regional transportation plan, to meet the needs expressed by the underserved communities. For example, the San Francisco Bay Area allocated 25\% of \$3 billion in anticipated revenue to be spent to benefit low-income communities and communities of color. A portion of these funds can be provided to underserved communities to assist them in identifying their needs, and investments should then be specifically targeted to benefit low-income populations within these areas (Marcantonio, 2015). 
Institutional challenges and a lack of clear equity indicators and targets are barriers to equity in regional transportation planning. Regional transportation plans frequently fail to indicate or clearly specify social equity goals or performance indicators and, without doing so, progress may never come (Martens, Golub \& Robinson, 2012; Martens \& Golub, 2014b). Inconsistent federal oversight standards, differences in agency planning capacity and support for equity analysis, and funding constraints at both the state and regional level are other ongoing barriers to equity in planning (Lowe, 2014; Amekudzi et al., 2012; Karner \& Niemeier, 2013). In addition, although most MPOs strive to involve historically disadvantaged communities in the planning process, doing so "...is not sufficient in and of itself to ensure that an agency achieves EJ outcomes” (Amekudzi et al., 2012).

\subsection{REVIEW OF MPO EQUITY PLANNING PRACTICES}

To identify the current state of the practice, the research team reviewed a cross section of MPO long-range transportation plans and environmental justice studies from across the U.S. The reviews of the MPO plans focused on a range of issues including: (1) defining and spatially locating communities of concern (COC); (2) methods to involve COC in the decision-making process; (3) methods for evaluating selected equity outcomes of plans; and (4) any performance measures for monitoring equity. This section summarizes key findings and observations as to the state of current practice for integrating equity into the MPO transportation planning process, documenting notable practices from MPOs.

\subsubsection{Defining and Locating Communities of Concern}

A key step in evaluating equitable distribution of benefits and burdens in transportation planning is defining and locating COCs. Title VI of the Civil Rights Act and Executive Order 12898 on Environmental Justice identify race, color, national origin and low-income status as factors that must be considered in equity analysis. However, many MPOs use additional factors to identify vulnerable groups. COCs are often defined as areas having greater-than-average populations of one or more of the following demographic groups:

- Minority

- Low-income

- Elderly (typically 65 years or older)

- Limited English Proficiency (LEP)

- Disabled

- Carless households

Although "low-income" is sometimes defined as households at or below the federal poverty level, it encompasses only the very poor (about $20 \%$ of households). Therefore, MPOs at times expand the definition to $185 \%$ or $200 \%$ of the federal poverty level to capture workingclass households and the working poor in their analysis. Several MPOs also included other variables related to economic disadvantage, such as:

- Single-parent households

- Female-headed households with children 
- Households receiving food stamps

- Households in neighborhoods with low to medium home values

- Households where the head has no high school education

Table 3 summarizes the various methods used by MPOs to define and locate COCs. Most MPOs used census data to identify areas where minority, low-income and other target populations exceeded regional averages for minority and low-income populations. A few MPOs, namely the Houston-Galveston Area Council and Delaware Valley Regional Planning Commission, used indices in their demographic analysis, as shown in Table 4.

\section{Table 3: MPO Methods for Identifying Communities of Concern}

\begin{tabular}{|c|c|c|}
\hline MPOs & Variables & Data Source(s) \\
\hline $\begin{array}{l}\text { Association of Bay Area } \\
\text { Governments/Metropolitan } \\
\text { Transportation Commission } \\
\text { (MTC, 2013) }\end{array}$ & $\begin{array}{l}\text { Low-income, minority, LEP, zero-vehicle } \\
\text { households, elderly ( } 75+\text { years old), persons with } \\
\text { disabilities, single-parent families }\end{array}$ & $\begin{array}{l}2000 \text { Bay Area } \\
\text { Travel Survey } \\
2010 \text { Census } \\
2010 \text { American } \\
\text { Community Survey }\end{array}$ \\
\hline $\begin{array}{l}\text { Atlanta Regional Commission } \\
\text { (ARC, 2011b) }\end{array}$ & $\begin{array}{l}\text { Elderly, no high school education, low to medium } \\
\text { housing values, low-income, minorities, LEP, and } \\
\text { disabled persons }\end{array}$ & 2009 ESRI data \\
\hline $\begin{array}{l}\text { Delaware Valley Regional } \\
\text { Planning Commission for } \\
\text { Pennsylvania } \\
\text { (DVRPC, 2013a) }\end{array}$ & $\begin{array}{l}\text { Low-income populations, minorities, elderly } \\
(75+) \text {, carless households, persons with } \\
\text { disabilities, LEP, and female head-of-household } \\
\text { with child populations; Degree of Disadvantage } \\
\text { (DOD) Index }\end{array}$ & 2010 Census \\
\hline $\begin{array}{l}\text { Hamptons Roads Transportation } \\
\text { Planning Organization } \\
\text { (HRTPO, 2014) }\end{array}$ & $\begin{array}{l}\text { Minorities, low-income, LEP, female head of } \\
\text { household, households receiving cash public } \\
\text { assistance or food stamps, elderly }(65+) \text {, carless } \\
\text { households, and persons with disabilities }\end{array}$ & $\begin{array}{l}\text { 2009-13 American } \\
\text { Community Survey }\end{array}$ \\
\hline $\begin{array}{l}\text { Houston-Galveston Area Council } \\
\text { (HGAC, 2011) }\end{array}$ & $\begin{array}{l}\text { Elderly (65+ years old), minorities, and low- } \\
\text { income populations; Environmental Justice Index }\end{array}$ & 2000 Census \\
\hline $\begin{array}{l}\text { New York Metropolitan } \\
\text { Transportation Council } \\
\text { (NYMTC, 2013); }\end{array}$ & Low-income and minority populations & 2000 Census \\
\hline $\begin{array}{l}\text { North Central Texas Council of } \\
\text { Governments } \\
\text { (NCTCOG, 2013) }\end{array}$ & $\begin{array}{l}\text { Low-income, minorities, elderly }\left(65^{+}\right) \text {, carless } \\
\text { households, female head of households, and } \\
\text { persons with disabilities }\end{array}$ & 2000 Census \\
\hline $\begin{array}{l}\text { Omaha-Council Bluffs Metro } \\
\text { Area Planning Agency } \\
\text { (OCBMPA, 2015) }\end{array}$ & $\begin{array}{l}\text { Low-income, minorities, carless households, and } \\
\text { transit-dependent populations }\end{array}$ & $\begin{array}{l}2010 \text { Census } \\
2013 \text { American } \\
\text { Community Survey }\end{array}$ \\
\hline $\begin{array}{l}\text { Polk Transportation Planning } \\
\text { Organization (PTPO, 2015b) }\end{array}$ & $\begin{array}{l}\text { Low-income, transportation-disadvantaged and } \\
\text { minority populations }\end{array}$ & $\begin{array}{l}\text { 2007-2011 American } \\
\text { Community Survey } \\
\text { data }\end{array}$ \\
\hline $\begin{array}{l}\text { Puget Sound Regional Council } \\
\text { (PMRG, 2014) }\end{array}$ & $\begin{array}{l}\text { Minorities, low-income, special-needs populations } \\
\text { (i.e., persons with disabilities, youth, seniors, LEP, } \\
\text { homeless persons, school-aged children, families } \\
\text { who have experienced domestic violence, veterans, } \\
\text { and limited literacy residents) }\end{array}$ & 2010 Census \\
\hline
\end{tabular}




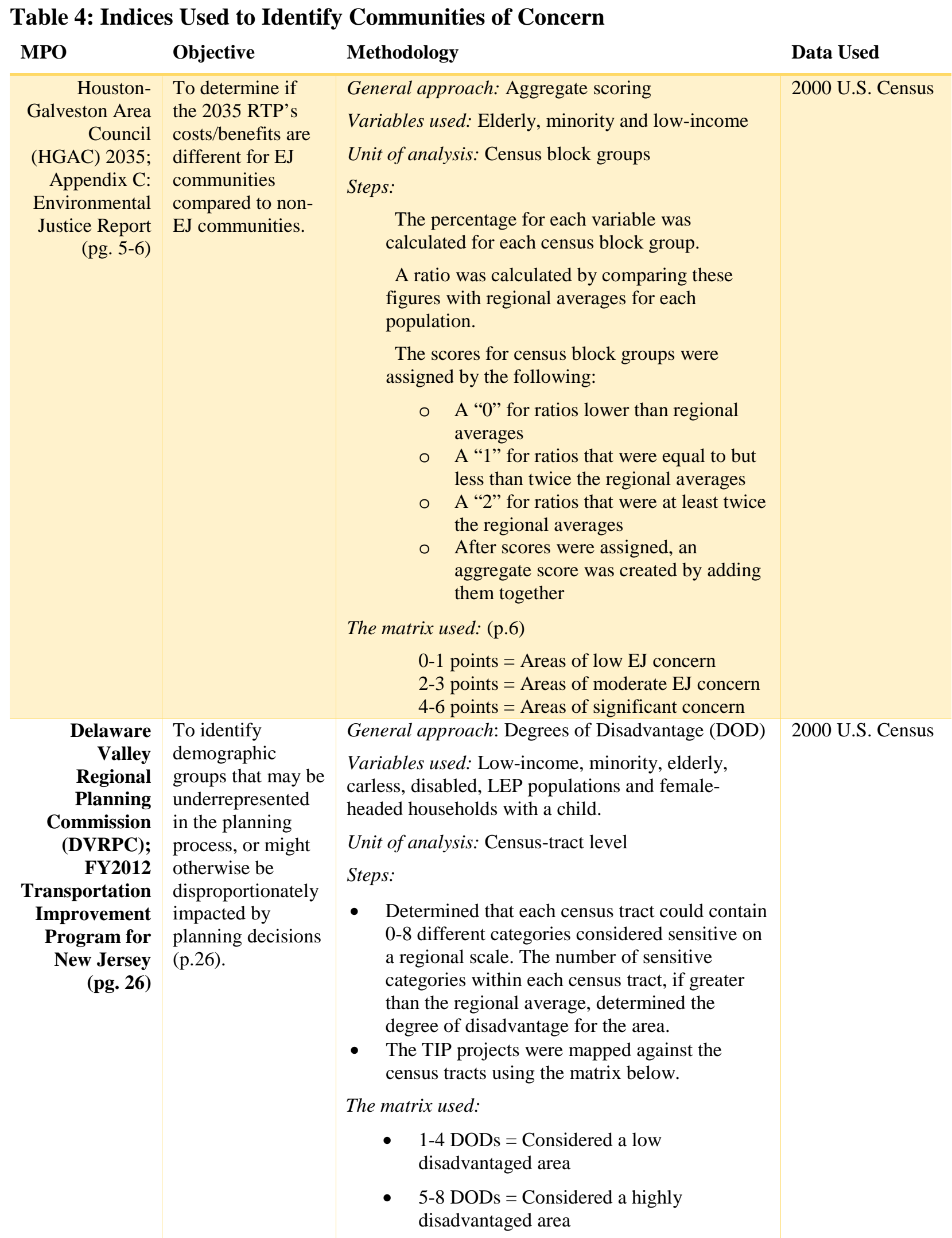




\subsubsection{Involving Communities of Concern}

MPOs use a variety of methods for involving COCs in the transportation decision-making process. Many provide translation services, work with community group partners, ensure that public facilities are accessible to disadvantaged populations, and have advisory committees that engage underserved populations in the transportation planning process.

For example, the Metropolitan Transportation Commission in Oakland, CA, conducted a public-opinion telephone survey specifically targeted to minorities and low-income populations, and partnered with community-based organizations to conduct workshops in low-income neighborhoods (MTC, 2005). Polk TPO in Central Florida communicates regularly with community groups that represent underserved populations; develops culturally sensitive outreach materials; and attends cultural festivals, such as the Hispanic Festival in Lakeland, to discuss planning activities and solicit community feedback. Table 5 illustrates some of the varied methods used by other MPOs to involve COCs.

\section{Table 5. Methods used by MPOs to Involve Communities of Concern \\ MPO \\ Methods}

Atlanta Regional Commission

(ARC, 2011)

New York Metropolitan Transportation Council (NYMTC, 2009)

Miami-Dade Metropolitan Planning Organization (MDMPO, 2014a)
- $\quad$ Focus groups and listening sessions are conducted to gather input from underserved communities.

- $\quad$ The MPO has a Social Equity Advisory Committee.

- $\quad$ The MPO partners with community groups and religious groups, which help underserved populations get involved in the planning process.

- $\quad$ MPO advisory groups act as mediums for community engagement.

- Public transportation departments disseminate information to non-profit groups, who represent and interact with minorities and low-income populations.

- Social media, local media outlets, press releases, and multilingual advertisements and handout materials in three most common languages.

- $\quad$ Materials are hand delivered or disseminated through venues and/or groups that serve lowincome, transit-dependent and disadvantaged populations.

- Community-based organizations help publicize meetings, which are held at neighborhood centers and libraries accessible to low-income residents. Translators are available at all public meetings.

- MPO has “Transportation Outreach Planner” who tailors involvement strategies to community context, literacy rates, income levels, cultural composition and religious affiliations. 


\subsubsection{Evaluating Accessibility and Transportation Options}

As discussed in section 1.4.3, the number of factors involved can make accessibility difficult to measure. MPOs have used a variety of methods to examine accessibility. Some MPOs measure accessibility by transit network coverage and connectivity, while others measure accessibility in terms of a particular type of destination, such as employment (Welch \& Mishra, 2013; Welch, 2013; Currie, 2010; Mamun, Lownes, Osleeb \& Bertolaccini, 2013). Still others use a combination of methods. Table 6 illustrates different metrics used by MPOs for accessibility analysis in relation to transportation modes as identified in the review of regional transportation plans.

For example, Polk TPO in Central Florida created a Mobility Index, which accounts for pedestrian and bicycle access, transit connectivity, and network gaps and barriers. Pedestrian and bicycle access was measured by network connectivity, development density, diversity of land uses, and the number of destinations within a certain distance (a quarter mile for pedestrians, one mile for bicycles). Transit connectivity was measured by the location, frequency and intensity of transit service. Network gaps and barriers were measured by gaps in connectivity (e.g., sidewalk gaps) and the presence of hindrances to walking and cycling (Polk TPO, 2015d). Overall accessibility was calculated by subtracting gaps and barriers, as discussed further in Appendix A.

\section{Table 6. MPO Measures of Accessibility and Transportation Options}

\begin{tabular}{|c|c|}
\hline MPO & Accessibility Measures and Metrics \\
\hline $\begin{array}{l}\text { Atlanta Regional Commission } \\
\text { (ARC, 2011) }\end{array}$ & $\begin{array}{l}\text { Potential Walking Demand: } \\
\text { Number of households, services, jobs, stores } \\
\text { people can walk to and/or receive goods/services } \\
\text { Multimodal Accessibility Measure: } \\
\text { Access to jobs via three travel modes: 45-minute } \\
\text { transit trip, 30-minute drive, and a 15-minute walk }\end{array}$ \\
\hline $\begin{array}{l}\text { Polk Transportation Planning Organization } \\
\text { (PTPO, 2015d) }\end{array}$ & $\begin{array}{l}\text { - Mobility Index: } \\
\text { Potential Access with Gaps Discount and Barriers } \\
\text { Discount } \\
\text { o Potential Access: } \\
\text { - Walking/Biking: Existence of } \\
\text { connectivity, dwelling density and } \\
\text { diversity in use } \\
\text { Transit Connectivity: Access via the } \\
\text { location, frequency and intensity of } \\
\text { transit service } \\
\text { Gaps: Transportation network gaps (i.e., gaps } \\
\text { in sidewalk network); discount factor up to } \\
\text { 25\% of the potential access } \\
\text { Barriers: Presence of hindrances to } \\
\text { walking/biking (i.e., roadway, waterway, } \\
\text { and/or railroad); discount factor up to 25\% of } \\
\text { the potential access }\end{array}$ \\
\hline $\begin{array}{l}\text { San Diego Association of Governments } \\
\text { (SANDAG, 2012) }\end{array}$ & $\begin{array}{l}\text { - Access to healthcare facilities, healthy food, transit } \\
\text { stops, parks and open space, and non-motorized } \\
\text { trails where more than } 50 \% \text { of their households } \\
\text { live within .6 miles walking distance of each } \\
\text { destination type }\end{array}$ \\
\hline
\end{tabular}


The San Diego Association of Governments (SANDAG) developed a Healthy Communities Atlas, which included measures of accessibility to certain health-related destinations. The Atlas measures access to healthcare facilities, transit stations, healthy food, parks and open space, and non-motorized trails. Census block groups were deemed "accessible" if they had more than $50 \%$ of households within walking distance (.6 mile) of any one of these healthy destinations (SANDAG, 2012).

The Atlanta Regional Commission measures walkability and multimodal accessibility. Potential for walking is measured by the number of destinations within a 15-minute walking distance. Multimodal accessibility is measured by the number of jobs accessible by a 45-minute transit trip, a 30-minute drive, and a 15-minute walk (ARC, 2011). Table 7 highlights a range of methodologies used by MPOs to examine accessibility.

Table 7: Examples of MPO Accessibility Analysis Methodologies

\begin{tabular}{|c|c|c|c|}
\hline MPO & Objective & Steps Taken & Source \\
\hline $\begin{array}{l}\text { Houston- } \\
\text { Galveston Area } \\
\text { Council } \\
\text { (HGAC); } \\
\text { Accessibility } \\
\text { Analysis - } \\
\text { Travel Times in } \\
\text { Transportation } \\
\text { Analysis Zone } \\
\text { (TAZ) Areas in } \\
\text { EJ Communities }\end{array}$ & $\begin{array}{l}\text { To determine if EJ } \\
\text { populations } \\
\text { currently, or are } \\
\text { expected to, } \\
\text { experience longer } \\
\text { travel times either } \\
\text { by automobile or } \\
\text { local transit due to } \\
\text { the } 2035 \text { RTP. }\end{array}$ & $\begin{array}{l}\text { Calculated average travel times for auto } \\
\text { and transit from each TAZ within EJ } \\
\text { communities to an identified TAZ area } \\
\text { with a major activity center. } \\
\text { - Using a travel demand model, the most } \\
\text { frequented TAZ from EJ communities was } \\
\text { identified and travel times to this TAZ } \\
\text { destination was calculated for the current } \\
\text { year of 2005, the year } 2035 \text { with the plan, } \\
\text { and year 2035 without building changes. } \\
\text { The more trips recorded to TAZs with } \\
\text { higher EJ populations, the more TAZ sites } \\
\text { were recommended for projects, especially } \\
\text { for pedestrians and bicyclists. }\end{array}$ & $\begin{array}{l}\text { Source: } 2035 \text { RTP, } \\
\text { Appendix C: } \\
\text { Environmental } \\
\text { Justice Report, } \\
\text { Pg.11-12. }\end{array}$ \\
\hline $\begin{array}{l}\text { Southern } \\
\text { California } \\
\text { Association of } \\
\text { Governments } \\
\text { (SCAG) }\end{array}$ & $\begin{array}{l}\text { To compare the } \\
\text { accessibility to } \\
\text { medical services } \\
\text { and } \\
\text { grocery/general } \\
\text { merchandise stores } \\
\text { between EJ and } \\
\text { non-EJ groups. }\end{array}$ & $\begin{array}{l}\text { Identified areas where stores were } \\
\text { accessible by walking, biking, and local } \\
\text { bus transit. } \\
\text { Using } 2008 \text { data, three- and five-mile radii } \\
\text { were used to determine the distance to } \\
\text { each. } \\
\text { Accessibility to these areas by EJ groups } \\
\text { was compared with that of non-EJ groups. }\end{array}$ & $\begin{array}{l}\text { (SCAG) 2012-2035 } \\
\text { RTAP: Sustainable } \\
\text { Communities } \\
\text { Strategy Towards a } \\
\text { Sustainable Future } \\
\text { Environmental } \\
\text { Justice Appendix } \\
\text { Accessibility } \\
\text { Analysis - Medical } \\
\text { Services and } \\
\text { Grocery/General } \\
\text { Merchandise Stores }\end{array}$ \\
\hline
\end{tabular}




\begin{tabular}{|c|c|c|c|}
\hline $\begin{array}{l}\text { Southern } \\
\text { California } \\
\text { Association of } \\
\text { Governments } \\
\text { (SCAG) }\end{array}$ & $\begin{array}{l}\text { To evaluate travel } \\
\text { times to places of } \\
\text { employment, } \\
\text { shopping } \\
\text { accessibility, and } \\
\text { accessibility to } \\
\text { public parks for EJ } \\
\text { groups. }\end{array}$ & $\begin{array}{l}\text { Created TAZ travel time matrix by } \\
\text { examining TAZ zones by mode (i.e., auto, } \\
\text { local bus transit, and all other transit) to } \\
\text { create a study area. Selected all TAZs } \\
\text { accessible with different transportation } \\
\text { modes within 45-minutes of travel. } \\
\text { Using SCAG's employment database, } \\
\text { medical facilities, general merchandise } \\
\text { stores, and grocery stores were identified, } \\
\text { as well as the growth projections for retail } \\
\text { jobs and number of total jobs within the } \\
\text { study area. In addition, measurements } \\
\text { included access to total acreage of parks. }\end{array}$ & $\begin{array}{l}\text { (SCAG) 2012-2035 } \\
\text { RTP: Sustainable } \\
\text { Communities } \\
\text { Strategy Towards a } \\
\text { Sustainable Future } \\
\text { Environmental } \\
\text { Justice Appendix } \\
\text { (pg. 63) }\end{array}$ \\
\hline
\end{tabular}

The North Jersey Transportation Authority (NJTPA) developed a methodology for evaluating the performance of transportation projects, including effects on accessibility (NJTPA, 2011). Dimensions of accessibility were access to jobs, access to labor force, access to regional amenities (such as hospitals, universities, retail activities, recreation, etc.), and access to community amenities. Bicycle and pedestrian projects were evaluated to determine which destinations became accessible by walking and bicycling as a result that previously were not accessible by certain segments of the population. As part of the project prioritization process, NJTPA uses improved accessibility for EJ communities as a major deciding factor. Data and metrics used in the assessment are provided in Table 8.

\section{Table 8: NJTPA Bicycle and Pedestrian Accessibility Methodology}

Data Sources and Inputs

- Locations of working-age population (U.S. Census Bureau) aggregated to TAZs

- Locations of jobs (from U.S. Census Bureau, Center for Economic Studies, Longitudinal Employer-Household Dynamics Program) aggregated to TAZs

- Locations of regional amenities (from GIS database of regional amenities)

- Locations of local amenities (from GIS database of local amenities)

- Peak-hour travel speed data for links in the NJRTM-E model network (from INRX or other vehicle probe data)

- $\quad$ NJRTM-E model network link attributes (link length, toll information)

Source: NJTPA, 2011, pgs. 3.10-16 - 3.10-17

Measures

Access to Community Amenities: Distance-based cumulative opportunity accessibility measure

Access to Destinations Other Than Community Amenities: Travel time-based cumulative opportunity accessibility measure 


\subsubsection{Examining Health and Safety Impacts}

Varying approaches are being used by MPOs to measure health and safety impacts and to reduce adverse impacts and/or improve health and safety outcomes for underserved communities. Table 9 compares the different approaches used by MPOs to measure bicycle and pedestrian safety, health and safety impacts, and air quality in COCs.

\section{Table 9. MPO Health and Safety Analysis}

\begin{tabular}{|c|c|c|c|}
\hline MPO & Bike/Ped Safety & $\begin{array}{l}\text { Health \& Safety } \\
\text { Impacts on COCs }\end{array}$ & $\begin{array}{l}\text { Air Quality Impact } \\
\text { Measurements }\end{array}$ \\
\hline $\begin{array}{l}\text { Atlanta Regional } \\
\text { Commission } \\
\text { (ARC, 2014) }\end{array}$ & $\begin{array}{l}\text { - Identifies crash locations by } \\
\text { mode to be targeted for } \\
\text { investment }\end{array}$ & $\begin{array}{ll}\text { - } & \text { Projects at crash } \\
\text { locations are } \\
\text { assumed to address } \\
\text { safety issues } \\
\text { - } \\
\text { Equitable Target } \\
\text { Areas (ETAs) } \\
\text { identify EJ } \\
\text { communities and } \\
\text { targets them for } \\
\text { investment }\end{array}$ & N/A \\
\hline $\begin{array}{l}\text { San Diego } \\
\text { Association of } \\
\text { Governments } \\
\text { (SANDAG, 2012) }\end{array}$ & $\begin{array}{l}\text { - } \\
\text { maps pedestrian- involved } \\
\text { motor vehicle crashes } \\
\text { vehicle crashes } \\
\text { - } \quad \text { Maps pedestrian and cyclist } \\
\text { crash rate } \\
\text { - IDs block groups by level of } \\
\text { safety and determines how } \\
\text { many are COC }\end{array}$ & $\begin{array}{l}\text { - Traffic Safety for } \\
\text { Youth } \\
\text { Designed to find } \\
\text { areas where } \\
\text { investment is } \\
\text { needed }\end{array}$ & $\begin{array}{l}\text { Measured impact } \\
\text { zones from } \\
\text { highways, rail } \\
\text { yards, ports } \\
\text { Determined } \\
\text { number of COC } \\
\text { block groups by } \\
\text { proximity to air } \\
\text { pollution sources }\end{array}$ \\
\hline $\begin{array}{l}\text { San Francisco } \\
\text { Metropolitan } \\
\text { Transportation } \\
\text { Council/Association } \\
\text { of Bay Area } \\
\text { Governments } \\
\text { (MTC, 2013) }\end{array}$ & - $\quad \mathrm{N} / \mathrm{A}$ & $\begin{array}{ll}\text { - } & \text { Emissions Density } \\
\text { - VMT Density }\end{array}$ & $\begin{array}{l}\text { Emissions } \\
\text { Distribution Index } \\
\text { results stratified by } \\
\text { pollution and } \\
\text { community type, } \\
\text { including COC }\end{array}$ \\
\hline
\end{tabular}

The growing interest in health impact assessments in transportation is also helping to inform equity analysis. SANDAG, for example, conducted a comprehensive analysis of health and safety in the San Diego metropolitan area, called the Healthy Communities Atlas, as mentioned above. The Atlas is accompanied by a set of GIS tools that can be used to identify geographic areas that support healthy lifestyles and areas in need of improvement (SANDAG, 2012). It also includes an index for measuring pedestrian and bicycle safety by census block group, which allows for comparison between COCs and the broader region.

The SANDAG Healthy Communities Atlas and its parent project resulted in the development of a "Regional Existing Conditions and Gap Analysis" for healthy communities, and a "Regional Health and Wellness Policy Framework and Performance Measures" that informed the development of the Regional Transportation Plan in subsequent updates. The Atlas and its parent project also resulted in the idea of healthy environments and communities being 
incorporated into systematic project evaluation criteria and network performance measures for transportation projects. Table 10 shows a comparison by SANDAG of cyclist safety in all block groups to cyclist safety in block groups with COCs. SANDAG also classified census block groups by proximity to air pollution sources, and analyzed the distribution between COCs and other areas. Table 6 shown earlier in the report provides accessibility metrics applied by SANDAG relative to health.

Table 10: Block Groups by Level of Cyclist Safety

\begin{tabular}{|l|l|l|}
\hline Level of Safety & All Block Groups & COC Block Groups \\
\hline Very High & $353(20 \%)$ & $240(14 \%)$ \\
\hline High & $352(20 \%)$ & $252(14 \%)$ \\
\hline Neutral & $352(20 \%)$ & $235(13 \%)$ \\
\hline Low & $352(20 \%)$ & $240(14 \%)$ \\
\hline Very Low & $353(20 \%)$ & $266(15 \%)$ \\
\hline All Categories & $1,762(100 \%)$ & $1,233(70 \%)$ \\
\hline
\end{tabular}

Source: SANDAG, 2012, p. 58

San Francisco Bay Area MTC’s most recent plan, Play Bay Area 2040, is their first to analyze health with regard to impacts on active transportation, collisions, and air quality. The plan compares the impacts of plans and projects on individuals and in aggregate, using the same measure of impacts as GHG emissions and job-creation - disability-adjusted life-years. Furthermore, as a unique practice, the plan uses morbidity and mortality as factors in their costbenefit analysis of transportation projects in the project selection process.

\subsubsection{Transportation and Housing Affordability}

In response to the rising cost of housing and transportation and the relationship between the two, MPOs are beginning to examine the impact of their long-range transportation plans on housing and transportation affordability (see Table 11Error! Reference source not found.). The Association of Bay Area Governments and Metropolitan Transportation Commission's 2013 Plan Bay Area was one of the few to apply a housing and transportation affordability measure to evaluate the equity impacts of various plan scenarios on COCs. Portland Metro and the Southern California Association of Governments in Los Angeles are also beginning to address this issue.

Plan Bay Area applies a combined housing and transportation cost index as a key performance measure when evaluating planning scenarios. The metric is calculated regionally to compare affordability between lower-income individuals (those making under \$38,000 a year) and those of higher income. Average housing costs per household are combined with transportation costs and divided by average income. This metric was added in response to concerns raised in the Plan Bay Area Equity Working Group.

The $\mathrm{H}+\mathrm{T}$ metric only considers impacts on residents based on income, whereas this measure works in conjunction with a measure of displacement risk that geographically locates and measures affordability impacts on areas with higher concentrations of "rent-burdened" communities of color (those paying over $30 \%$ of their income on rent). The metric does not, 
however, account for other anti-displacement policy tools such as rent control and inclusionary zoning that would potentially increase affordability (MTC, 2013).

Portland Metro’s 2014 Regional Transportation Plan includes a similar housing cost and transportation affordability index as a performance target. The MPO set a goal of reducing the average percentage of income spent on housing and transportation from $43 \%$ to $25 \%$. The plan concludes that despite transportation costs remaining constant, the overall index will continue to rise to $51 \%$ by the year 2040. Metro is currently rigorously evaluating and expanding its equity metrics, including the methodology and evaluation of this target (Metro, 2014).

The Southern California Association of Governments (SCAG) 2012 Regional Transportation Plan coordinated a transportation equity working group that called for the inclusion of housing and transportation affordability as a metric. Toward that end, SCAG conducted an analysis of the risk of gentrification and displacement. The SCAG methodology looked at gentrification in transit-oriented communities (TOCs), which are defined as neighborhoods within a half-mile distance of existing rail stations, compared to the greater region and High Quality Transit Areas (HQTAs), on a census block group level.

\section{Table 11. Housing plus Transportation Cost Affordability}

\begin{tabular}{|c|c|}
\hline MPO & Metric \\
\hline $\begin{array}{l}\text { Association of Bay Area Governments and } \\
\text { Metropolitan Transportation Commission - } \\
\text { Equity Analysis Report Including Title VI, } \\
\text { Environmental Justice and Equity Analysis. } \\
\text { Bay Area Plan: A Strategy for a Sustainable } \\
\text { Region. July 2013. }\end{array}$ & $\begin{array}{l}\text { Combined housing and transportation index evaluates } \\
\text { impacts based on income. Combined with displacement } \\
\text { risk metric to evaluate impacts on communities of color } \\
\text { specifically. }\end{array}$ \\
\hline $\begin{array}{l}\text { Southern California Association of } \\
\text { Governments - Environmental Justice } \\
\text { Appendix. (RTP) (FY2012-2035). }\end{array}$ & $\begin{array}{l}\text { No metric for affordability, but does have displacement } \\
\text { risk measure that highlights areas with a high percentage } \\
\text { of minority population, poverty rate, share of } 65+ \\
\text { population, percentage of households without a car, } \\
\text { percentage of non-English speakers, population without a } \\
\text { high school diploma, and percentage of renters. }\end{array}$ \\
\hline $\begin{array}{l}\text { Metro (Portland) Regional Government. - } 2014 \\
\text { Regional Transportation Plan. }\end{array}$ & $\begin{array}{l}\text { Combined housing and transportation performance target } \\
\text { for system-wide impacts on affordability. Not comparative } \\
\text { spatially. }\end{array}$ \\
\hline $\begin{array}{l}\text { San Diego Association of Governments } \\
\text { (SANDAG) - San Diego Forward: The } \\
\text { Regional Plan (2050) (RTP) (Appendix S) }\end{array}$ & $\begin{array}{l}\text { Percent of households with housing costs greater than } 35 \% \\
\text { of income. Annual income needed to afford fair market } \\
\text { rent. }\end{array}$ \\
\hline
\end{tabular}

The SCAG methodology measured differences in the percentage of minority population, poverty rate, share of 65+ population, percentage of households without a car, percentage of nonEnglish speakers, population without a high school diploma, and percentage of renters. SCAG also used a Gentrification Index developed by the University of Chicago, which applies a more robust set of measures including female-headed households, youth and adults with college degrees. According to the analysis, Hispanics and seniors have seen less growth in TOCs during the 2000-2013 period, while median gross rent has increased and median gross income has decreased in these TOCs compared to the greater region. SCAG recognizes these different 
growth patterns as possible evidence of gentrification and displacement - but acknowledges the limits of its statistical testing and the need for continued monitoring.

\subsubsection{Determining Distributional Equity of Investments}

The simplest way that MPOs address the concern of distributional equity is by mapping the spatial distribution of projects or project spending and determining if they are proportionally distributed between COCs and non-COCs, whether in terms of dollar investments per capita, total number of projects, or other measures. The Delaware Valley Regional Planning Commission, for example, measures whether areas determined to have high "degrees of disadvantage" (above average populations of COCs) have equal spatial distributions of proposed number of projects in the transportation improvement program compared to the region as a whole (VRPC, 2013).

A shortcoming of this approach is that transportation investments in disadvantaged communities may not necessarily benefit those communities in proportion to benefits accrued by other populations (Marcantonio, 2015). For example, a commuter rail project through a lowincome minority neighborhood may be a major investment, but the benefits would not accrue to that neighborhood if little or no transit station access is provided. To address this issue, some MPOs are beginning to use more nuanced approaches to determine whether or to what extent COCs benefit from the project investments in their area. These approaches include those mentioned below in relation to accessibility, health, safety and related issues.

For example, the Southern California Association of Governments (SCAG) goes beyond the geographic distribution of projects to examine the specific impact of that distribution on COCs. One component of this analysis is the distribution of travel time and distance savings from implementing the proposed transportation plan. Demographic data and mode usage statistics for each transportation analysis zone (TAZ) are used to compare time savings per trip for both car and transit options. Time savings are calculated based on each group's usage of the system, so that adjustments can be made to address any disproportionate burdens or benefits (SCAG, 2012)

SCAG further evaluates jobs-housing imbalance, as well as accessibility to jobs and employment, to determine the impacts of project distribution. The jobs-housing imbalance metric examines the extent to which lower-income workers are disproportionately impacted by congestion and high transportation costs. The accessibility metric examines what amenities and places of employment are feasible to get to as a result of the planned improvements. Both of these measures are calculated for different COCs, in comparison to the average for the region as a whole. Table 12 includes these examples of MPO distributional equity analysis. 


\section{Table 12. Distributional Equity of Investments}

\section{MPO Methods}

Delaware Valley Regional Planning

Commission (2013)

Transportation Improvement Program (TIP)

(FY2013-2016)

Southern California Association of

Governments (2012) - Environmental Justice

Appendix. (RTP) (FY2012-2035)

North Jersey Transportation Planning Authority (2005) - NJTPA Environmental

Justice Regional Analysis, Proportional

Distribution of Benefits of

Transportation Projects in the NJTPA Region
- Spatial distribution of transportation projects between census tracts with high and low "Degrees of Disadvantage.”

- Analyzes distribution of time and distance travel savings, jobs-housing imbalance implications, and accessibility of employment for EJ communities compared with that of the general population.

- $\quad$ Overlaid map of transportation investments with EJ community maps to determine the spatial distribution of investments.

The Atlanta Regional Commission mapped the per capita transportation investments in Equitable Target Areas (ETAs) compared to non-ETAs to determine whether the levels and types of investments in COCs were appropriate (ARC, 2014). Transportation investments were examined on a per capita basis for transit, roadway, bike and pedestrian projects for ETAs versus non-ETAs on a dollar basis, as shown in Figure 2.
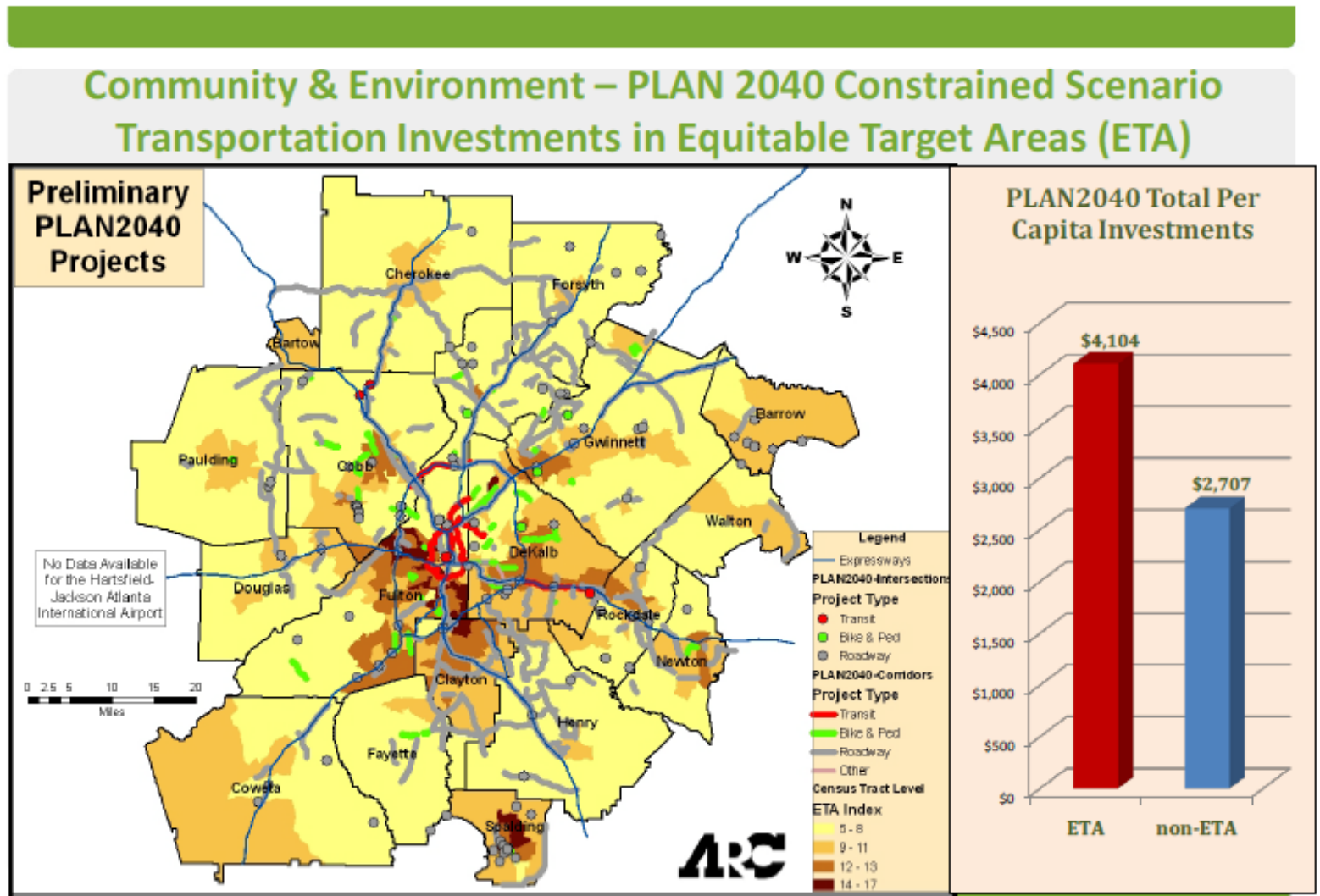

Figure 2. Transportation investments in equitable target areas (ETAs).

Source: ARC, 2014, pg. 33 


\subsubsection{Performance Measurement}

Adoption of performance measures or indicators guides the evaluation of transportation plans in relation to plan policies and objectives and is essential to the systematic integration of equity into the MPO planning and project prioritization process. As the saying goes, "What gets measured gets done." Performance measures are used in evaluating the who, what, where, when, why, and how of the impacts of transportation plans and projects, and serve to inform transportation agencies and decision-makers. The adoption of equity-based performance targets allows transportation agencies to measure their progress, and allows the community to hold them accountable. Therefore, these indicators and targets should be developed through direct involvement of the affected communities.

MPOs evaluated transportation system performance, as well as equity, in a multitude of ways, both qualitative and quantitative. Some MPOs provide explicit equity objectives in their plan and others integrate equity considerations into some or all of their planning objectives. The above sections describe the variety of possible lenses through which performance indicators and targets are created - public involvement, accessibility, health, safety, affordability, and distribution of investment. Additional examples of performance indicators used by MPOs relative to their equity goals are shown in Table 13.

\section{Table 13: MPO Equity-Related Indicators and Benchmarks}

\begin{tabular}{|c|c|c|c|}
\hline MPO & $\begin{array}{l}\text { Performance } \\
\text { Indicator }\end{array}$ & Measurement & Targets or Benchmarks \\
\hline $\begin{array}{l}\text { Atlanta Regional } \\
\text { Commission } \\
\text { (ARC) }\end{array}$ & $\begin{array}{l}\text { Access to jobs via } \\
\text { multiple travel modes. }\end{array}$ & $\begin{array}{l}\text { Access to jobs via three travel modes: } \\
\text { 45-minute transit, 30-minute drive, \& } \\
\text { 15-minute walk. }\end{array}$ & $\begin{array}{l}\text { Sets a base index to } \\
\text { compare to multiple } \\
\text { scenarios and } 2040 \\
\text { aspirations }\end{array}$ \\
\hline $\begin{array}{l}\text { Miami-Dade } \\
\text { MPO }\end{array}$ & $\begin{array}{l}\text { Reverse commute } \\
\text { opportunities for } \\
\text { disadvantaged } \\
\text { communities. } \\
\text { Projects that support } \\
\text { redevelopment areas. }\end{array}$ & $\begin{array}{l}\text { Transit service route miles from cities } \\
\text { and central areas in the AM peak } \\
\text { period. } \\
\text { Transit service route miles and highway } \\
\text { lane to centerline miles within } .5 \text { miles } \\
\text { of redevelopment areas. }\end{array}$ & No targets set \\
\hline $\begin{array}{l}\text { Plan Bay Area } \\
\text { (MTC) }\end{array}$ & $\begin{array}{l}\text { Affordable Housing } \\
\text { and Transportation } \\
\text { Choices. } \\
\text { Equitable Growth } \\
\text { Healthy Communities } \\
\text { Making the Jobs- } \\
\text { Housing Connection } \\
\text { Equitable Mobility }\end{array}$ & $\begin{array}{l}\text { Estimates produced at neighborhood } \\
\text { TAZ level of certain socioeconomic } \\
\text { and travel characteristics for } 2010 \text { base } \\
\text { year and } 2040 \text { forecasts: } \\
\text { - Housing and Transportation } \\
\text { - Affordability } \\
\text { - } \quad \text { Potential for Displacement } \\
\text { - } \quad \text { Average Commute Time } \\
\text { - Average Non-Commute Travel } \\
\quad \text { Time }\end{array}$ & No targets set \\
\hline $\begin{array}{l}\text { Southern } \\
\text { California } \\
\text { Association of } \\
\text { Governments }\end{array}$ & $\begin{array}{l}\text { Accessibility (parks and } \\
\text { employment services) }\end{array}$ & $\begin{array}{l}\text { Percentage of parks/employment } \\
\text { services reachable within a 30-minute } \\
\text { off-peak travel time via automobile, } \\
\text { bus/rail via automobile, bus/rail via } \\
\text { walking. }\end{array}$ & No targets set \\
\hline
\end{tabular}


Ideally, performance indicators and targets are developed for each key stage of the transportation process, beginning with community engagement. A balance must be struck between goals and objectives that are easily operationalized, but costly or time-consuming to measure. MPOs looking to methodically prioritize their objectives to address social equity must recognize the inherent trade-offs between social equity and other objectives (Manaugh, 2014).

Table 14 illustrates example performance measures for equity and community engagement in the transportation planning process, as developed by Skeo Solutions, a firm specializing in collaborative equity planning. Additional example performance indicators and targets are provided in the case study analyses summarized in Section 2.

Table 14. Example Equity and Community Engagement Performance Measures

Action Measures

Inputs
What's invested
Number of low-income,
people of color and LEP
community members who
participate during planning
Number of community
organizations who
participate during planning

Outputs
What's created
Dollar amount of
community-based
transportation investments
prioritized for low-income,
people of color, and LEP
neighborhoods

Measure of growth in community member trust in transportation agency

Measure of community knowledge related to transportation plans, alternatives, impacts and benefits

Measure of growth of agency knowledge related to community stakeholders, goals and issues

Description of regulatory or policy changes related to community input

\section{Results Measures}

$\begin{aligned} & \text { Outcomes } \\ & \text { What happens }\end{aligned}$
$\begin{aligned} & \text { Number of community- } \\ & \text { prioritized intersection safety } \\ & \text { improvements in low-income, } \\ & \text { people of color, and LEP } \\ & \text { neighborhoods }\end{aligned}$

Miles of community-prioritized bike lane and sidewalk improvements in low-income, people of color, and LEP neighborhoods that improve access to key destinations such as jobs, educational opportunities, health or social service destinations, and/or healthy food outlets.

Hours of reduced idling due to community-prioritized traffic light optimization in lowincome neighborhoods

Number of modal options available to access key destinations of a neighborhood within a given timeframe

Number of households and schoolchildren protected from community-prioritized truck route realignment

\section{Impact What changes}

Increase in number of residents walking and biking as a primary means to access key destinations

Reduced bike and pedestrian accidents/deaths Improved air quality monitoring results

Reduced asthma incidents

Decrease in amount of time it takes to access jobs centers or other destinations via transit

Source: SKEO, 2016, www.skeo.com. 


\subsection{CASE STUDY ANALYSIS}

This section describes exploratory case study applications of equity analysis conducted by the University of South Florida (CUTR) and Portland State University research teams in collaboration with their respective MPO partners - Hillsborough MPO (Tampa) and Metro (Portland). Below is a summary of the results of those applications and technical assistance efforts.

\subsection{HILLSBOROUGH MPO - TAMPA, FL}

\subsubsection{Introduction and Background}

Hillsborough County is a major economic and cultural center in the state of Florida. It is home to the cities of Tampa, Temple Terrace and Plant City (Hillsborough County, 2016). At a 2015 population of approximately 1.35 million people, Hillsborough County is the fourth most populous county in Florida. The population continues to increase, with nearly $10 \%$ growth between April 2010 and June 2015. Other than the downtown core areas and a few activity centers, the county is characterized by large areas of relatively low density and residential development, with commercial development focused in strips on major roadways. The region has no fixed rail transit service (other than a streetcar system with limited service connecting a couple neighborhoods around downtown Tampa), a limited bus transit network and relatively infrequent bus service.

Historically, Hillsborough MPO has not systematically addressed equity in its regional transportation planning process. Rather, the MPO has worked to identify and address the needs of transportation-disadvantaged populations within the context of specific plans and studies. These efforts included those reflected in the Tri-County Area Regional Mobility Needs study, the Transportation Disadvantaged Service Plan, and the MPO long-range transportation plan, as discussed below.

\subsubsection{Planning Context}

The county’s Transportation Disadvantaged Service Plan (TDSP) has been the primary venue for addressing the transportation needs of historically disadvantaged communities in Hillsborough County. Using 2010 census data, a demographic profile was prepared to identify potential transportation-disadvantaged populations (HMPO, 2015a). Variables included: population density for ages 60 and above; census tracts with median income less than $80 \%$ of the county median; density of households with an income to poverty ratio of less than $125 \%$; density of zero-vehicle households; disabled people and all OASDI beneficiaries; and total employment by Traffic Analysis Zone (TAZ). A trip factor was applied to the number of severely disabled (0.049) and the number of low-income who were not disabled with no access to vehicle or transit (1.899), resulting in a total number of needed trips for these populations. 
The last countywide needs assessment conducted for the transportation-disadvantaged population indicated that $32 \%$ of the Hillsborough County population qualified as transportation disadvantaged, 15\% were living in poverty, 29,000 children were defined as disabled, and residents ages 60 and above were scattered about the county. The unmet trip need in Hillsborough County was estimated at 12,123 trips on a given day or 4,424,941 trips for the year of 2011.

The analysis further revealed that the needs of the transportation-disadvantaged population relative to access to employment and education, healthcare, shopping and recreation are often not met due to a lack of funding, limited fixed-route services, gaps in bicycle and pedestrian infrastructure, land use and bodies of water (the bay), and a long history of lowdensity development. The plan also outlined regional needs within and beyond Hillsborough County, such as the need for regional fixed-route/express services, infrastructure improvements, and regional paratransit services.

Another equity-related planning study was the Tri-County Area Regional Mobility Needs study conducted in 2007 to meet funding criteria for the Special needs of the Elderly and Individuals with Disabilities, Job Access and Reverse Commute, and New Freedom programs under SAFETEA-LU. Census data was used to identify and map concentrations of persons living below the poverty line, other low-income households, population density, persons with disabilities, and elderly populations (persons 65 years of age or older) (HMPO, 2014b). Onequarter-mile and three-quarter-mile buffers were placed around all fixed and paratransit routes to determine accessibility to transit in these areas.

A 2014 update of the Tri-County Area Regional Mobility Needs study further identified key healthcare and long-term care facilities outside of the transit service area. A TransitOrientation Index was also created to identify transit-dependent segments of the population or those historically more likely to use public transportation, such as older adults, youth, and lowincome or no vehicle households. The Transit-Orientation Index was calculated using block group data from the 2011 American Community Survey. Demographic characteristics, including population density per square mile, proportion of population ages 60 and above, proportion of population ages 16 and below, and proportion of population living below the poverty line were mapped to identify concentrations of transit-oriented persons, as defined by the index (HMPO, 2014b).

Concentrations of transit-oriented persons were compared to existing transit routes to determine if the routes were serving populations in the region most likely to need public transit. The analysis revealed that although Hillsborough and Pasco counties have underserved areas with high or very high transit orientation, many existing routes serve areas identified as high or very high transit-orientation index areas (HMPO, 2014b). The transit agencies did not make any substantial changes to service based on the findings of the report or the transit-orientation index.

The 2040 long-range transportation plan has addressed equity in the context of safety and access to jobs and services. The development of the LRTP began with asking the public, through online surveys and MPO meeting surveys, about preferred growth scenarios termed Bustling Metro, New Corporate Centers and Suburban Dream. Each growth pattern was evaluated with a set of standardized performance measures to give the public an idea of how these types of growth would impact a variety of indicators. Among these performance indicators was "Access to Jobs from Under-Employed Communities,” the average home-to-work trip length for environmental justice communities, and the percentage with access to transit service that operates at 30-minute frequencies as forecasted using the regional travel demand model (HMPO, 2014a, p. 33). 
The 2040 Long-Range Transportation Plan (LRTP) estimated the size of the population unserved by the fixed-route transit system in 2040, and used existing census data to estimate the potential 2040 transportation-disadvantaged population. The LRTP recognized that fixed-route bus service serves $52 \%$ of the county's population, leaving $48 \%$ without access to the fixed-route bus system, though paratransit service (Sunshine Line) is available for eligible transportation disadvantaged residents with needs-based transit. Paratransit will pick up and drop off transportation disadvantaged residents at their destination, or take them to an accessible fixedroute bus stop depending on the needs of the passenger.

The LRTP makes investment-level projections (low-high) for bus routes, with each level identifying the transportation disadvantaged population unserved by transit in 2040 and the annual paratransit trips needed in 2040. The plan evaluates eight financial scenarios and expenditures based on those scenarios. Transportation-disadvantaged services remain constant regardless of increases in revenue (HMPO, 2014a). Although under these different scenarios fixed-route bus service is anticipated to increase in frequency and spatial coverage, which will naturally provide accessibility to transportation disadvantaged populations, the funds are not specifically targeted at addressing these populations.

An additional performance indicator in the LRTP includes reducing crashes and addressing vulnerable road users. Hillsborough County, at the time of the LRTP's adoption, ranked $12^{\text {th }}$ in the nation for traffic fatalities per 100,000 residents. The Hillsborough MPO developed the Congestion Management/Crash Mitigation Process: Crash Severity Reduction Report in 2012 to identify the most common types of severe and fatal crashes. The LRTP outlines the goal of reducing injuries and crashes per 100 million vehicle miles traveled, and improving safety for all road users through a multitude of safety enhancement project strategies (e.g., roundabouts, medians, bike lanes, sidewalks, pedestrian islands, etc.) (HMPO, 2014a).

Hillsborough County's LRTP is updated on a five-year cycle and the Transportation Disadvantaged Service Plan is updated annually. The 2040 LRTP was adopted at the end of 2014, and the adoption of the 2045 LRTP update can be expected in 2019. Since the Transportation Disadvantaged Service Plan is updated on an annual basis, its update will be adopted in mid-2017.

\subsubsection{Methods to Involve Communities of Concern}

Throughout the development of the Tri-County Area Regional Mobility Needs report (HMPO, 2014b), Long Range Transportation Plan (HMPO, 2014a), and the Transportation Disadvantaged Service Plan (HMPO, 2015a), there were notable efforts to engage COCS in the planning process. The primary method in Hillsborough County has been through public meetings, presentations, surveys and workshops in specific planning activities.

The most concerted effort to involve COCS occurred during development of the Hillsborough County Transportation Disadvantaged Service Plan (TDSP) (HMPO, 2015a). The public was encouraged to attend and provide input regarding the plan at Transportation Disadvantaged Coordinating Board meetings. A major part of the TDSP public involvement effort included a survey and the first Hillsborough County Human Services Transportation Forum, where social service providers were invited to engage in a conversation on unmet client transportation needs and potential solutions to address these needs. The online survey was distributed to these social service providers to determine unmet needs of the transportation disadvantaged clients served by these agencies (HMPO, 2015a). 
During the Tri-County Area Regional Mobility Needs study, extensive outreach was performed through public workshops in Hillsborough, Pasco and Pinellas counties in coordination with the Florida Department of Transportation. Participants were asked to respond to a series of questions through electronic polling or open discussion related to mobility needs (HMPO, 2014b). An online survey was also made available to the public through Survey Monkey in an effort to reach as many people as possible.

Presentations were given to Transportation Disadvantaged Local Coordinating Boards (LCBs) to update board members on the findings from the public outreach process and results of the mapping analysis. The LCBs facilitated discussion regarding ways to gather additional input on the needs of the elderly and disabled populations (HMPO, 2014b). The Hillsborough County Transportation Disadvantaged Coordinating Board also took public comment at the beginning of each board meeting for the Transportation Disadvantaged Service Plan (HMPO, 2015a).

In developing “Imagine Hillsborough,” the 2040 LRTP, Hillsborough MPO used online and paper surveys, interactive kiosks placed throughout the county, and public meetings and presentations asking participants to select their preferred growth scenarios. As a method to involve COCs, kiosks were placed in areas that were heavily populated by low-income populations and placed in locations that low-income populations frequented, such as clinics (HMPO, 2014a).

The previous efforts to engage low-income and minority populations and other COCs have been largely part of broader public involvement activities. This study of equity in regional planning assisted the MPO in further defining and locating concentrations of the various populations identified as COC. The map and data could be used by the county in future planning efforts to better target their public involvement and outreach activities. Through that process, and the results of the accessibility, affordability and safety analysis, COCs could be engaged in identifying priority projects in their area.

\subsubsection{Priority Issues}

For its LRTP update, scheduled for completion in 2019, the Hillsborough MPO is interested in expanding its approach to identifying and addressing the transportation needs of COCs in the region. The MPO staff, through their previous planning and public involvement efforts, indicated a need for a greater variety of analysis measures and methods to better define and locate COCs, as well as accessibility of pedestrians, cyclists and transit-users to jobs and services. The MPO further indicated interest in methods to evaluate public health, safety and the distributional equity of investments. The research team added an assessment of housing plus transportation costs to the analysis for additional insight into affordability issues in the region as a whole. Below is a discussion of methods used to examine these measures and examples of the GIS analysis for selected measures. Also included are example performance indicators for consideration by the MPO in future long-range planning and transportation-disadvantaged service planning. 


\subsubsection{Methodology}

\subsubsection{Identifying Communities of Concern}

The first step of the analysis was to provide the MPO with a systematic method of defining and locating COC for future equity analysis. The research team worked with MPO staff to establish a methodology and set of variables for this purpose. A goal of the MPO for the regional analysis was to be as inclusive as possible of the various populations that are or could be transportation disadvantaged. One way the team addressed this goal was to expand the definition of low income beyond the very poor to include those at or below $185 \%$ of the federal poverty level. A threshold methodology was selected for use in locating COCs.

The data for the variables was obtained from the American Community Survey (ACS, 2010-2014). Relative concentrations of each population were then identified and mapped on the block group level based on whether a variable met or exceeded the countywide average by one standard deviation. The specific ACS variables and thresholds used in the analysis are listed in Table 15.

\section{Table 15: Identifying Communities of Concern}

\begin{tabular}{|c|c|c|c|}
\hline $\begin{array}{l}\text { Equity } \\
\text { Dimension }\end{array}$ & Data Source & Metric & Comments \\
\hline $\begin{array}{l}\text { Low-Income } \\
\text { Communities }\end{array}$ & $\begin{array}{l}\text { U.S. Census Bureau and American } \\
\text { Community Survey (ACS). } \\
\text { Households Living In Poverty } \\
\bullet \quad \text { B17017 - POVERTY } \\
\text { STATUS IN THE PAST } \\
\text { 12 MONTHS BY } \\
\text { HOUSEHOLD TYPE BY } \\
\text { AGE OF } \\
\text { HOUSEHOLDER } \\
\text { Link to Table Description }\end{array}$ & $\begin{array}{l}\text { Block groups with percentage } \\
\text { of households living at or } \\
\text { below } 185 \% \text { of poverty line }\end{array}$ & $\begin{array}{l}185 \% \text { of the poverty line } \\
\text { is used to include a } \\
\text { broader population of } \\
\text { economically } \\
\text { disadvantaged persons. } \\
\text { At or below the poverty } \\
\text { line includes only the } \\
\text { very poor. }\end{array}$ \\
\hline $\begin{array}{l}\text { Zero-Vehicle } \\
\text { Households }\end{array}$ & $\begin{array}{l}\text { U.S. Census Bureau and American } \\
\text { Community Survey (ACS). } \\
\text { Households with Zero Vehicles } \\
\text { Available } \\
\qquad \quad \text { B25044 - TENURE BY } \\
\text { VEHICLES AVAILABLE } \\
\text { Link to Table Description }\end{array}$ & $\begin{array}{l}\text { Block groups with percentage } \\
\text { of zero vehicle households } \\
\text { more than } 1 \text { standard } \\
\text { deviation above the } \\
\text { countywide average (average } \\
=2 \% \text { ). }\end{array}$ & \\
\hline Minorities & $\begin{array}{l}\text { U.S. Census Bureau and American } \\
\text { Community Survey (ACS). } \\
\text { Minority Population - African } \\
\text { American, Hispanic, Asian, } \\
\text { American Indian, and or Alaskan } \\
\text { Native. } \\
\qquad \text { B03002 - HISPANIC OR } \\
\text { LATINO ORIGIN BY } \\
\text { RACE } \\
\text { Link to Table Description }\end{array}$ & $\begin{array}{l}\text { Block groups with percentage } \\
\text { of minority population more } \\
\text { than } 1 \text { standard deviation } \\
\text { above the countywide } \\
\text { average (average }=46.8 \% \text { ). }\end{array}$ & $\begin{array}{l}\text { Census information } \\
\text { designates table as only } \\
\text { Hispanic or Latino origin } \\
\text { by race, but includes all } \\
\text { other races and } \\
\text { ethnicities. }\end{array}$ \\
\hline
\end{tabular}




\begin{tabular}{|c|c|c|c|}
\hline Elderly & $\begin{array}{l}\text { U.S. Census Bureau and American } \\
\text { Community Survey (ACS). } \\
\text { Over } 65 \\
\bullet \quad \text { B01001 - SEX BY AGE } \\
\text { Link to Table Description }\end{array}$ & $\begin{array}{l}\text { Block groups with percentage } \\
\text { of population } \geq 65 \text { years old } \\
\text { more than } 1 \text { standard } \\
\text { deviation above the } \\
\text { countywide average (average } \\
=14.02 \%) \text {. }\end{array}$ & \\
\hline Youth & $\begin{array}{l}\text { U.S. Census Bureau and American } \\
\text { Community Survey (ACS). } \\
\text { Under } 18 \\
\bullet \quad \text { B01001 - SEX BY AGE } \\
\text { Link to Table Description }\end{array}$ & $\begin{array}{l}\text { Block groups with percentage } \\
\text { of population }<18 \text { years old } \\
\text { more than } 1 \text { standard } \\
\text { deviation above the } \\
\text { countywide average (average } \\
=21.7 \% \text { ). }\end{array}$ & \\
\hline $\begin{array}{l}\text { Limited } \\
\text { English } \\
\text { Proficiency } \\
\text { (LEP) }\end{array}$ & $\begin{array}{l}\text { U.S. Census Bureau and American } \\
\text { Community Survey (ACS). } \\
\text { Limited English Proficiency } \\
\bullet \quad \text { B16002 - HOUSEHOLD } \\
\text { LANGUAGE BY } \\
\text { HOUSEHOLD LIMITED } \\
\text { ENGLISH SPEAKING } \\
\text { STATUS } \\
\text { Link to Table Description } \\
\end{array}$ & $\begin{array}{l}\text { Block groups with percentage } \\
\text { of LEP population more than } \\
1 \text { standard deviation above } \\
\text { the countywide average } \\
\text { (Average }=5.9 \% \text { ). }\end{array}$ & \\
\hline Disability & $\begin{array}{l}\text { U.S. Census Bureau and American } \\
\text { Community Survey (ACS). } \\
\text { - C23023 - SEX BY } \\
\text { DISABILITY STATUS } \\
\text { BY FULL-TIME WORK } \\
\text { STATUS IN THE PAST } \\
\text { 12 MONTHS FOR THE } \\
\text { POPULATION } 16 \text { TO } 64 \\
\text { YEARS } \\
\text { Universe: Population } 16 \text { to } 64 \text { years } \\
\text { Link to Table Description }\end{array}$ & $\begin{array}{l}\text { Block groups with percentage } \\
\text { of disabled full-time workers } \\
\text { in past } 12 \text { months more than } \\
1 \text { standard deviation above } \\
\text { the countywide average } \\
\text { (average }=10.8 \% \text { ). }\end{array}$ & \\
\hline $\begin{array}{l}\text { Communities } \\
\text { of Concern }\end{array}$ & $\begin{array}{l}\text { U.S. Census Bureau and American } \\
\text { Community Survey (ACS) } \\
\text {-All previous data }\end{array}$ & $\begin{array}{l}\text { Block groups that contain } 2 \\
\text { or more of the variables listed } \\
\text { above }\end{array}$ & $\begin{array}{l}\text { Use of } 2 \text { or more } \\
\text { variables helps to } \\
\text { identify greatest } \\
\text { concentrations of } \\
\text { communities of concern. } \\
\text { Given that the majority } \\
\text { of the county has census } \\
\text { tracts with } 1 \text { community } \\
\text { of concern, using } 2 \\
\text { highlights those areas or } \\
\text { potentially greatest need. }\end{array}$ \\
\hline
\end{tabular}

A composite map of all block groups with one or more variables that exceeded the countywide average by at least one standard deviation was then prepared. The resulting map included a majority of the county, largely due to low-income populations meeting our definition. To further identify relative concentrations of transportation-disadvantaged persons in the region, and because nearly the entire county was identified as containing at least one of these COCs, a second map was produced including only those block groups where any two or more variables exceeded the countywide average by one standard deviation (see Figure 3). This approach was 
selected by the MPO and research team as being both inclusive and appropriate for use in the regional planning equity analysis. The lighter gradation depicts areas where two of the variables overlap, and the darker gradation depicts areas which contain three or more variables. Maps of each COC variable were also provided to the MPO for further analysis of transportation needs of each specific population.

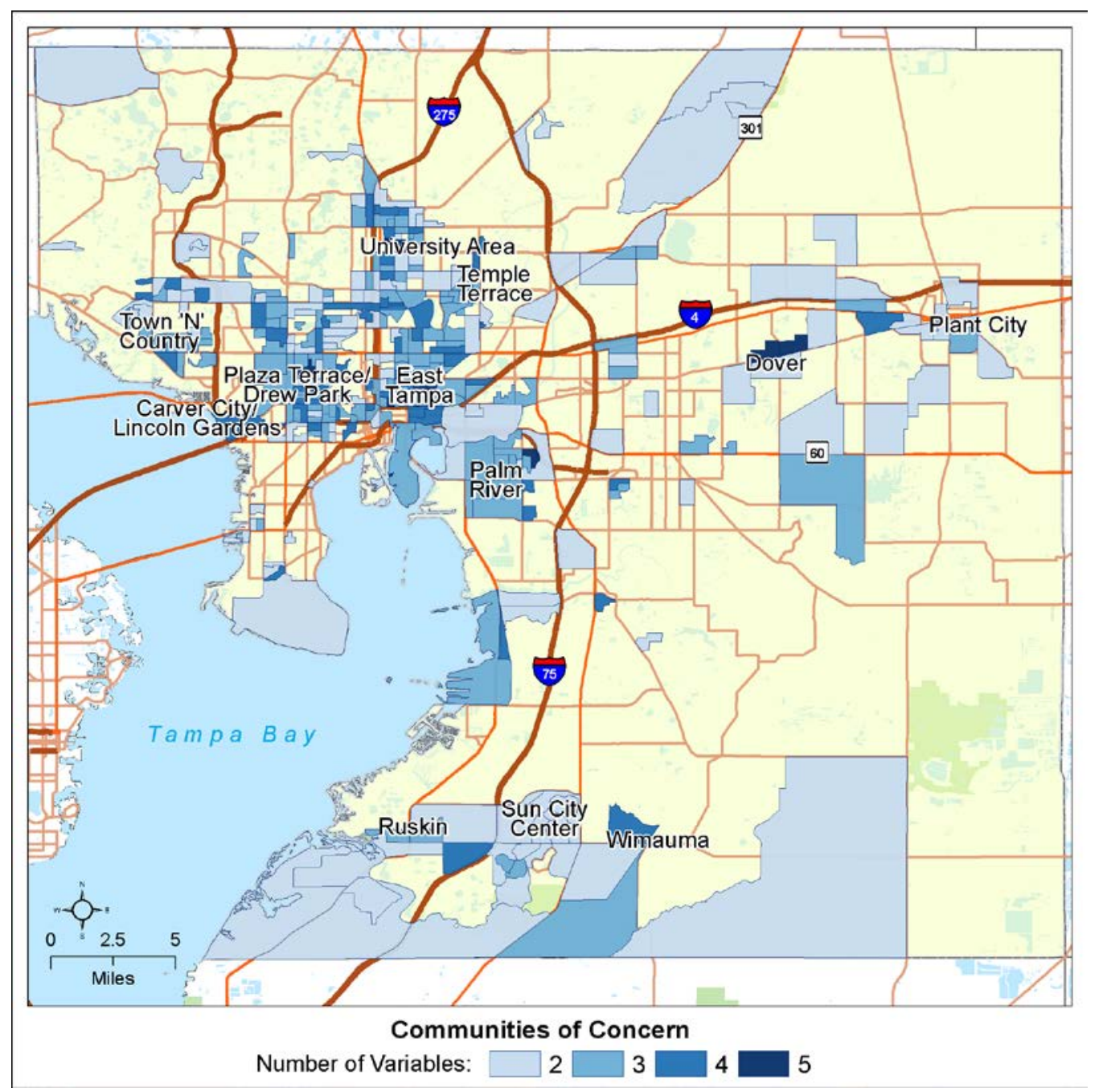

Figure 3. Hillsborough communities of concern.

\subsubsection{Identifying Essential Destinations}

The next step of the analysis aimed to identify where these populations were likely to travel. Identifying essential destinations provides insight as to priority areas for investment in infrastructure and services that support non-auto travel by COC, as well as the broader population. For this step, the team used Census LEHD Origin-Destination Employment Statistics by the NAICS employment codes listed in Table 16. This employment data was used as a proxy to determine where essential services and destinations are located. 
The countywide employment density for these jobs and services was calculated, and Census block groups in the top $15 \%$ of blockgroups based on employment density were identified as essential destinations. The results are illustrated in Figure 4.

\section{Table 16: Identifying Essential Destinations}

\begin{tabular}{|l|l|l|}
\hline Dimension & Data Source & Indicator \\
\hline $\begin{array}{l}\text { Essential } \\
\text { Destinations }\end{array}$ & $\begin{array}{l}\text { United States Census Bureau: LEHD Origin- } \\
\text { Destination Employment Statistics (LODES) }\end{array}$ & $\begin{array}{l}\text { Selection method: } \\
\text { 1) Rank based Index of Blockgroups } \\
\text { based on the number of jobs per square } \\
\text { mile }\end{array}$ \\
& 6 employment NAICS codes used include: & 2) selecting the top 15\% blockgroups \\
& $\begin{array}{l}\text { 2. } \quad \text { Educational services } \\
\text { 3. Arts, entertainment, and recreation }\end{array}$ & \\
& 5. Accommodation and food services & \\
& 6. All other services (except public & \\
& administration) & \\
\hline
\end{tabular}

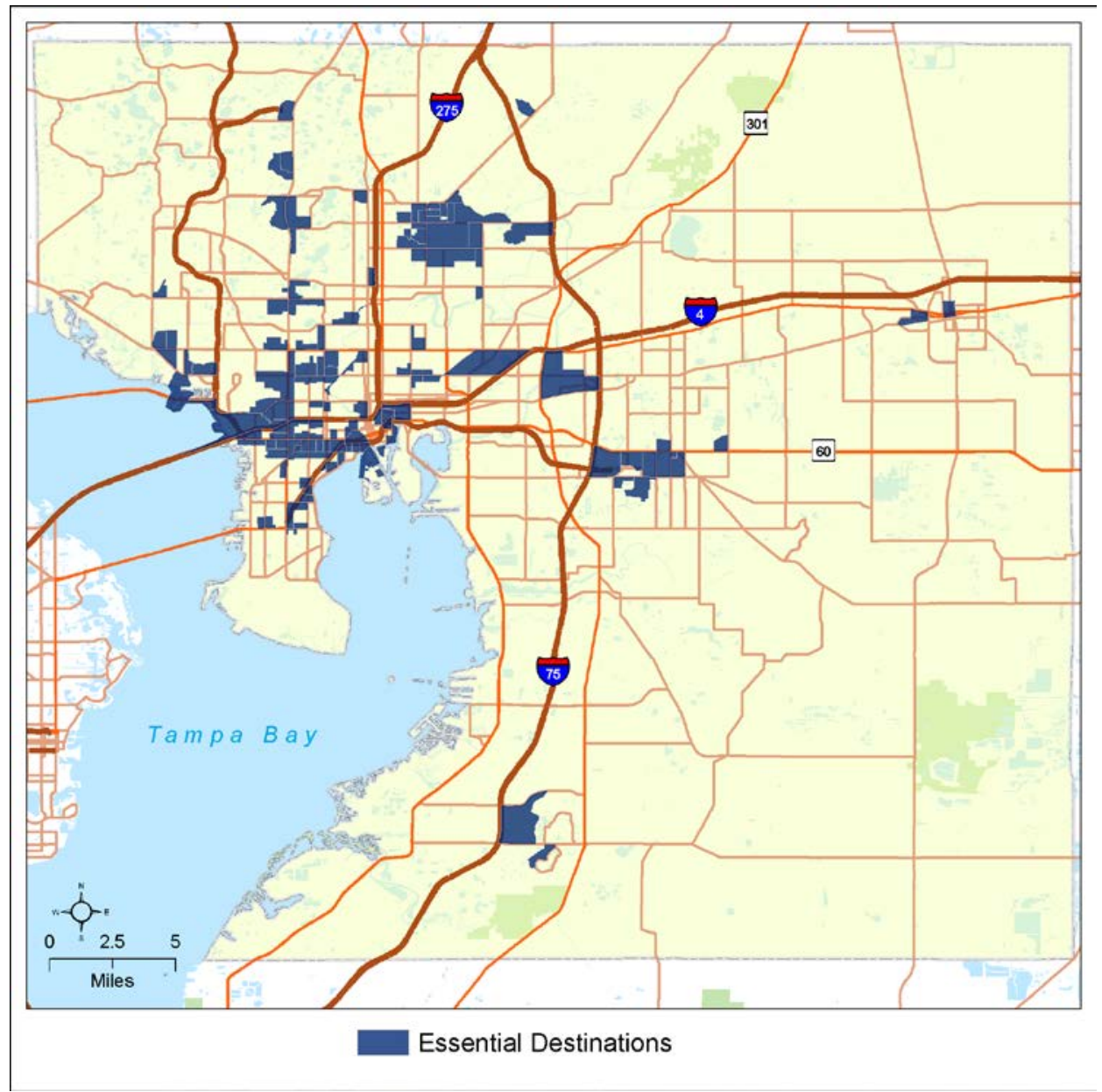

Figure 4: Essential destinations in Hillsborough County. 


\subsubsection{Exploring Accessibility}

Accessibility was measured for pedestrians, cyclists and transit users. Accessibility dimensions, data sources, and example indicators and targets are provided in Table 17. To begin, areas of relative underinvestment in bicycle and pedestrian facilities were identified using data on sidewalk and bicycle facility coverage from the Hillsborough MPO. The countywide average of centerline miles to bicycle or pedestrian facilities was calculated with only arterial and collector roadways used for the bicycle facility analysis. The available data was slightly out of date in this rapidly growing region, but was deemed by the research team and MPO to be of high enough fidelity for the analysis.

Block groups with a sidewalk to centerline mile ratio of $<1$ or bicycle facility to centerline mile ratio of $<1$ (excluding block groups with less than 500 persons per square mile) were identified to locate populated areas with low sidewalk and bicycle facility coverage. A sidewalk or bicycle facility to centerline mile ratio of 1 represents a sidewalk or bicycle facility on at least one side of every included road in the block group. For bicycle facility coverage, local roads were excluded from the analysis, as bicycle facilities are typically reserved for arterial and collector streets.

To measure accessibility, COC block groups identified as having low pedestrian (Figure 5) and bicycle (Figure 6) facility coverage that are located within one mile of essential destinations were identified. This methodology provides insight as to priority areas for future investment - that is, areas with high concentrations of COC that have low bicycle and pedestrian accessibility to essential destinations.

Table 17: Accessibility Metrics for Consideration by Hillsborough MPO

\begin{tabular}{|c|c|c|c|c|}
\hline \multirow{2}{*}{$\begin{array}{l}\text { Accessibility } \\
\text { Dimension }\end{array}$} & \multirow[b]{2}{*}{ Data Sources } & \multirow[b]{2}{*}{ Indicator } & \multicolumn{2}{|c|}{ Example Performance Targets } \\
\hline & & & Countywide & $\begin{array}{c}\text { Communities of } \\
\text { Concern }\end{array}$ \\
\hline \multirow[t]{2}{*}{$\begin{array}{l}\text { Pedestrian } \\
\text { Accessibility to } \\
\text { Essential } \\
\text { Destinations/Sidewalk } \\
\text { Coverage }\end{array}$} & \multirow[t]{2}{*}{$\begin{array}{l}\text { Hillsborough } \\
\text { MPO sidewalk } \\
\text { cover data. } \\
\text { U.S. Census } \\
\text { Bureau for } \\
\text { block group } \\
\text { boundary data }\end{array}$} & \multirow{2}{*}{$\begin{array}{l}\text { Identified block } \\
\text { groups with a } \\
\text { sidewalk to } \\
\text { centerline mile of } \\
<1 \text {. Communities } \\
\text { of Concern with } \\
\text { low sidewalk } \\
\text { coverage within } 1 \\
\text { mile of Essential } \\
\text { Destinations. }\end{array}$} & $\begin{array}{l}\text { By } 2040 \text {, increase } \\
\text { the ratio of } \\
\text { centerline miles to } \\
\text { sidewalk miles by } \\
\text { [25\%] compared to } \\
2014 \text {. }\end{array}$ & $\begin{array}{l}\text { By } 2040 \text {, increase the } \\
\text { ratio of centerline miles to } \\
\text { sidewalk miles in } \\
\text { communities of concern } \\
\text { by [50\%] compared to } \\
2014 \text {. }\end{array}$ \\
\hline & & & \multicolumn{2}{|c|}{$\begin{array}{l}\text { By } 2040 \text {, achieve a ratio of centerline miles to } \\
\text { sidewalk miles of } 2 \text { within } 1 \text { mile of all essential } \\
\text { destinations. }\end{array}$} \\
\hline \multirow[t]{2}{*}{$\begin{array}{l}\text { Bicyclist Accessibility } \\
\text { to Essential } \\
\text { Destinations/Bicycle } \\
\text { Facility Coverage }\end{array}$} & \multirow{2}{*}{$\begin{array}{l}\text { Hillsborough } \\
\text { County MPO } \\
\text { for Bike Lane } \\
\text { information. } \\
\text { U.S. Census } \\
\text { Bureau for } \\
\text { block group } \\
\text { boundary data. }\end{array}$} & \multirow{2}{*}{$\begin{array}{l}\text { Identified block } \\
\text { groups with a } \\
\text { bicycle facility to } \\
\text { centerline mile } \\
\text { ratio of }<1 \\
\text { excluding local } \\
\text { roads. } \\
\text { Communities of } \\
\text { Concern with low } \\
\text { bicycle facility } \\
\text { coverage within } 1 \\
\text { mile of Essential } \\
\text { Destinations. }\end{array}$} & $\begin{array}{l}\text { By } 2040 \text {, increase } \\
\text { the ratio of } \\
\text { centerline miles to } \\
\text { bicycle facility } \\
\text { miles by [25\%] } \\
\text { compared to } 2014 \text {. }\end{array}$ & $\begin{array}{l}\text { By } 2040 \text {, increase the } \\
\text { ratio of centerline miles to } \\
\text { bicycle facility miles in } \\
\text { communities of concern } \\
\text { by [50\%] compared to } \\
2014 .\end{array}$ \\
\hline & & & \multicolumn{2}{|c|}{$\begin{array}{l}\text { By 2040, achieve a ratio of centerline miles to } \\
\text { bicycle facility miles of } 2 \text { on all collectors and } \\
\text { arterials within } 1 \text { mile of all essential } \\
\text { destinations. }\end{array}$} \\
\hline
\end{tabular}




\begin{tabular}{|c|c|c|c|c|}
\hline $\begin{array}{l}\text { Transit Access to Jobs } \\
\text { access to jobs within } 45 \\
\text { minutes by bus }\end{array}$ & $\begin{array}{l}\text { Smart } \\
\text { Location } \\
\text { Database } \\
\text { www.epa.gov/ } \\
\text { smartgrowth/s } \\
\text { mart-location- } \\
\text { mapping\#SLD }\end{array}$ & $\begin{array}{l}\text { Rank based index } \\
\text { of transit block } \\
\text { groups based on } \\
\text { number of jobs } \\
\text { within } 45 \text {-minute } \\
\text { transit commute } \\
\text { (As per the Smart } \\
\text { Location } \\
\text { Database). Worst } \\
\text { (lowest 15\%) } \\
\text { transit served } \\
\text { COC block } \\
\text { groups }\end{array}$ & $\begin{array}{l}\text { By 2040, Increase } \\
\text { percentage of jobs } \\
\text { accessible via } 45 \\
\text { minute transit } \\
\text { commute by [25\%] } \\
\text { compared to } 2014 \text {. }\end{array}$ & $\begin{array}{l}\text { By 2040, increase the } \\
\text { percentage of jobs } \\
\text { accessible via } 45 \text {-minute } \\
\text { transit commute from } \\
\text { COC block groups by } \\
\text { [50\%] compared to } 2014 \text {. }\end{array}$ \\
\hline
\end{tabular}

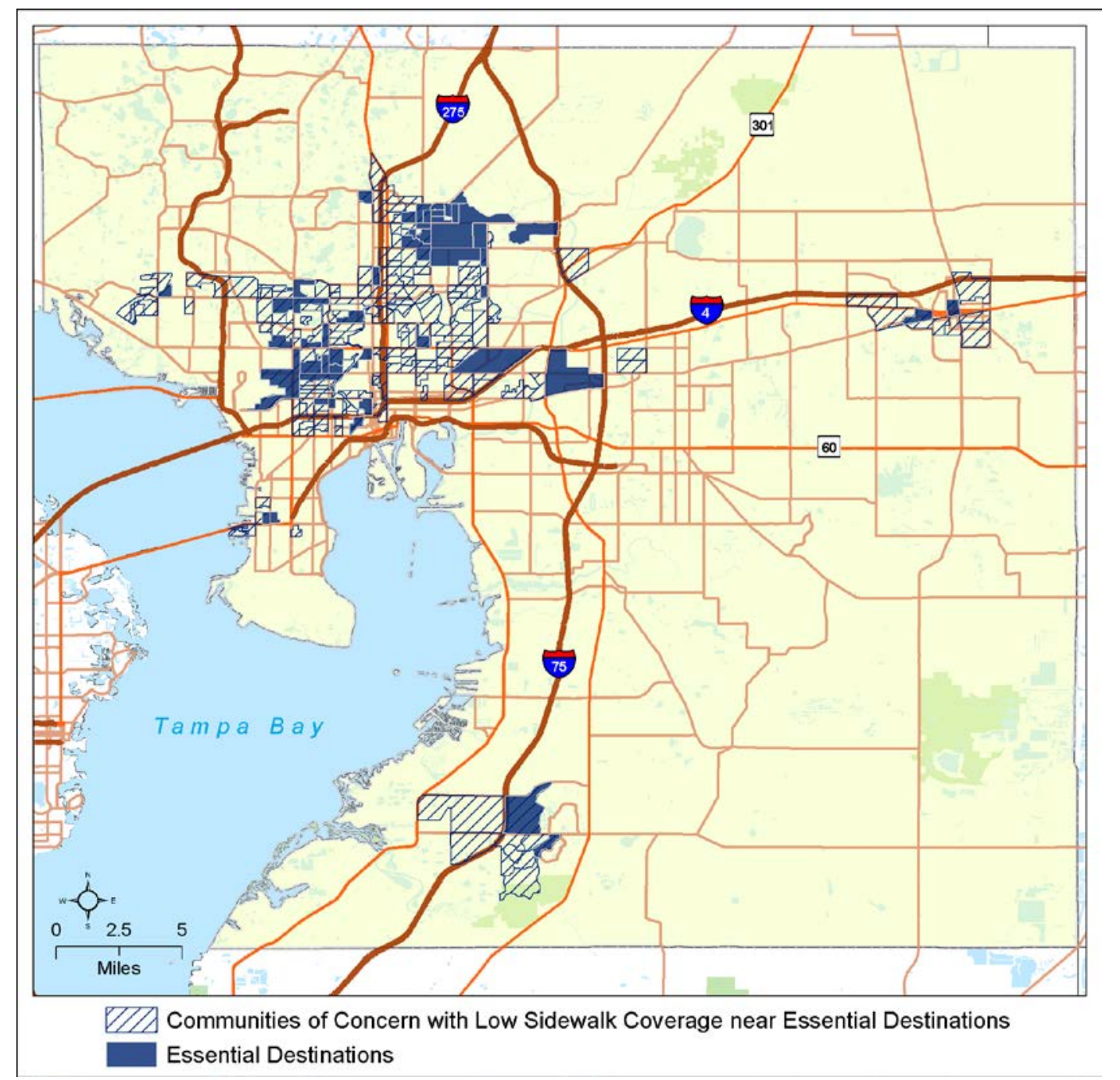

Figure 5: Communities of concern with low pedestrian accessibility to essential destinations. 


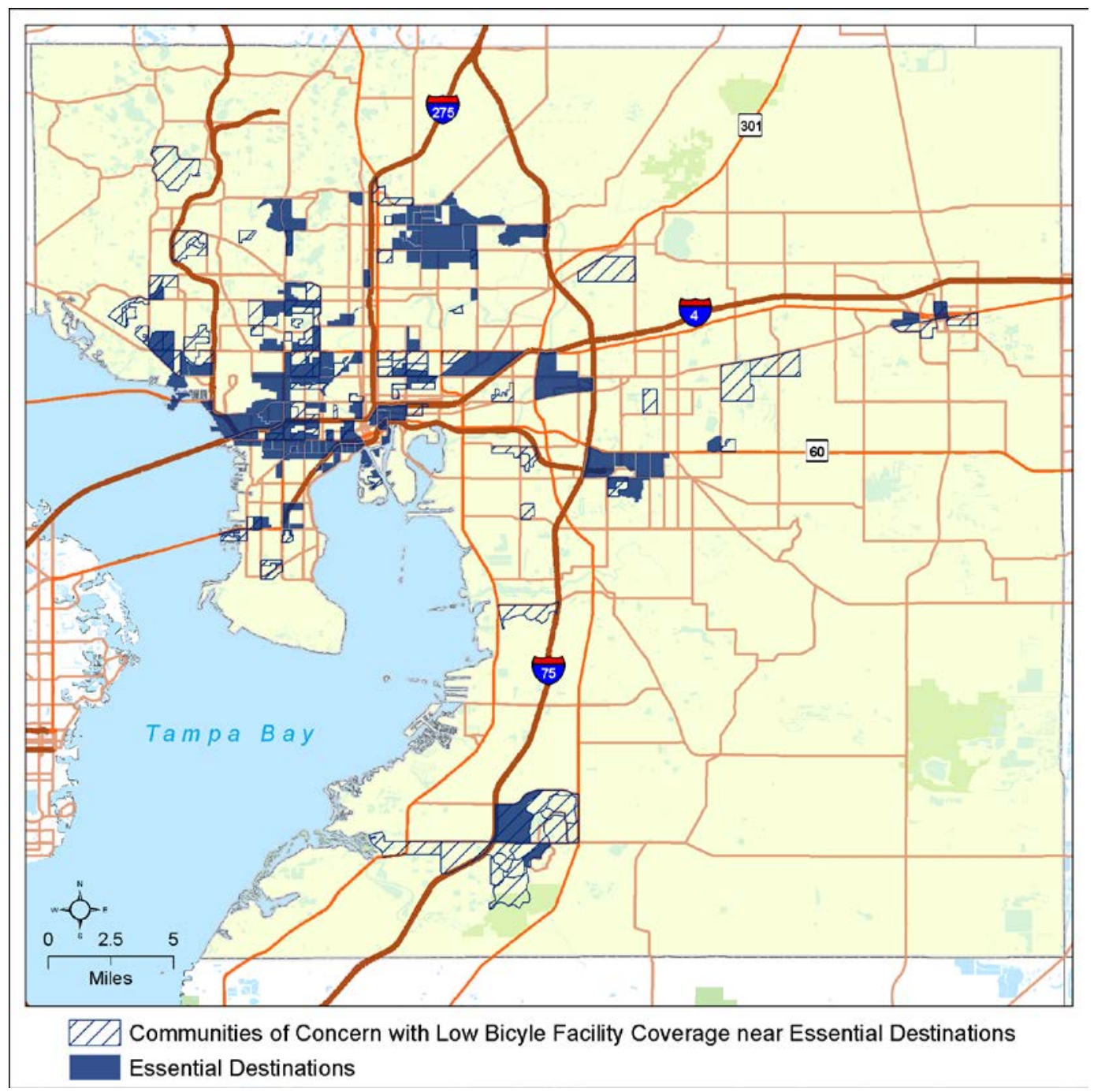

Figure 6: Communities of concern with low bicycle accessibility to essential destinations.

Transit access to jobs was analyzed using the Smart Location Database. These data, available from the U.S. Environment Protection Agency, rely on General Transit Feed Specification (GTFS) data from transit agencies that includes stops, routes and schedules. Most transit agencies that provide service within MPOs provide GTFS data, which captures about 95\% of all ridership nationally. Given its widespread availability, this data is an excellent way for MPOs and other regional agencies to explore transit accessibility to employment. At the time of this study, this data was current through 2012-2013.

Hillsborough County is characterized by a lack of “premium” transit service (e.g., light rail, high-quality bus rapid transit) and low bus service frequency. Therefore, most workers in the region find it necessary to commute to work by single occupant automobile. To evaluate transit access to jobs in Hillsborough County, a rank-based index was created of the total number of jobs accessible via transit within 45 minutes in transit-served block groups. The lowest $15 \%$ of block groups (representing about one standard deviation) were identified as areas that offer the least access to employment via bus transit (Figure 7). Block groups with the poorest transit access to employment that also contain two or more COC were identified (Figure 8). 


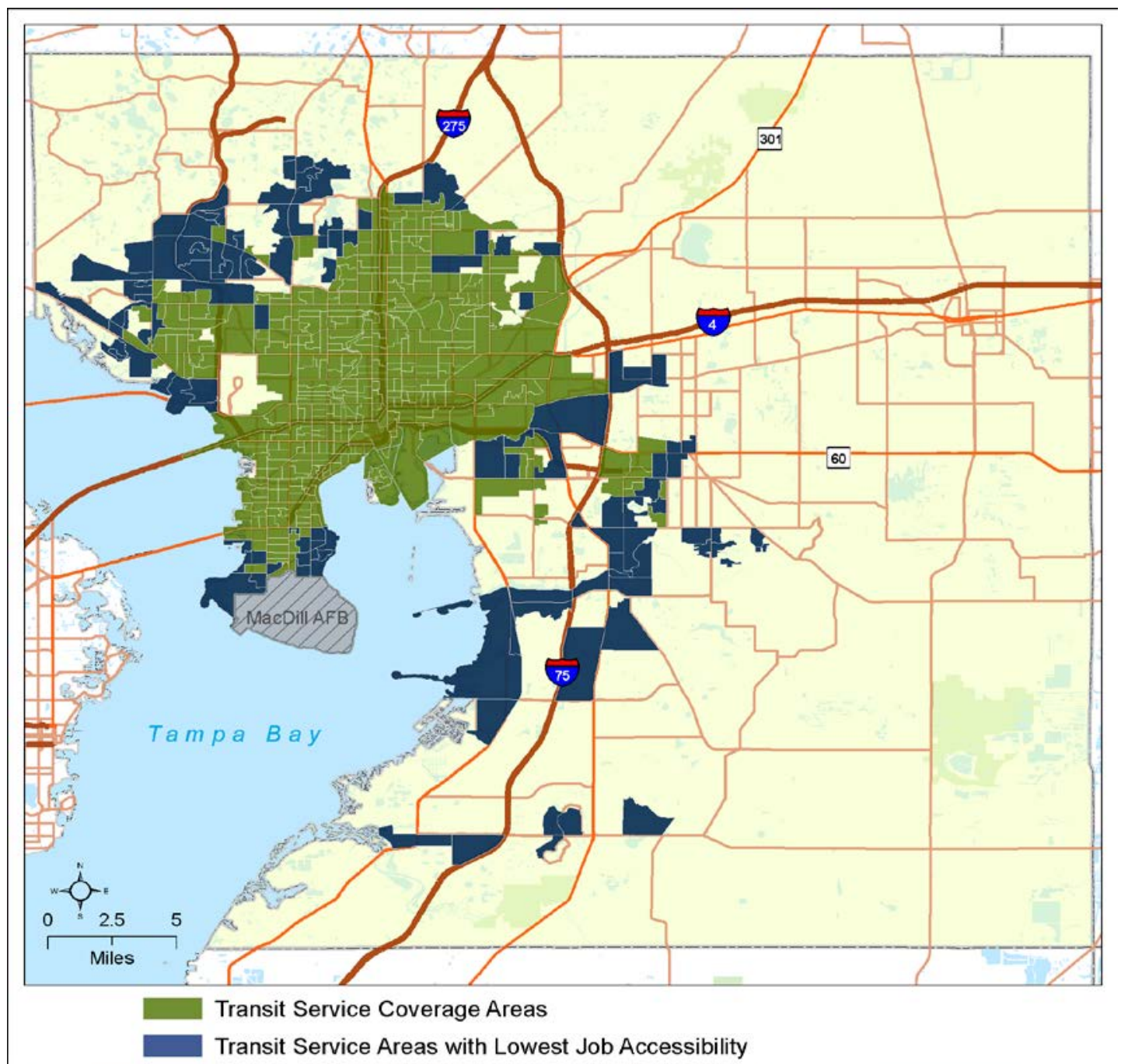

Figure 7: Areas with the least job accessibility within 45 minutes via transit. 


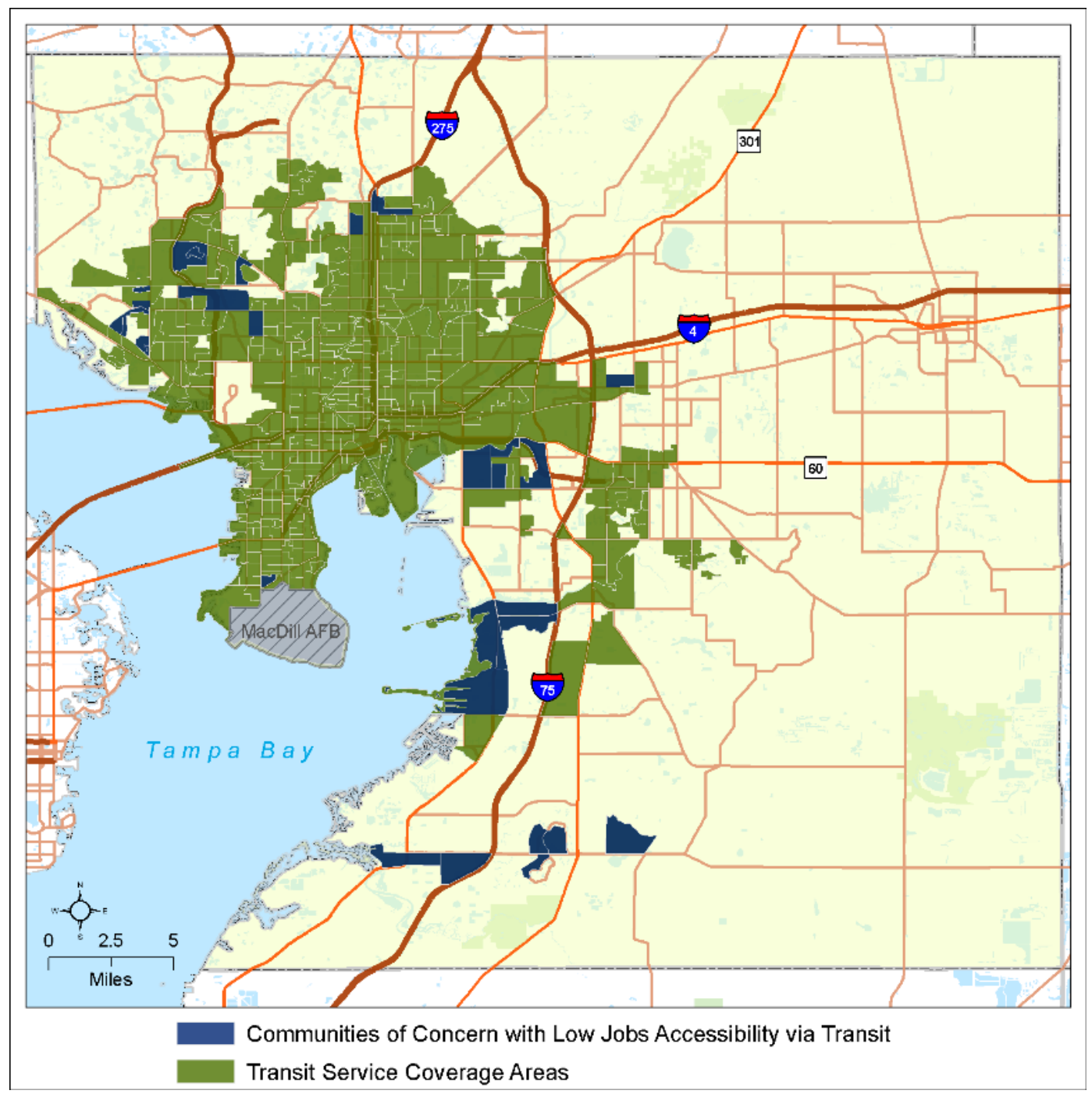

Figure 8: Communities of concern with the least job accessibility within 45 minutes via transit.

\subsubsection{Housing + Transportation Affordability}

The Housing + Transportation index database from the Center for Neighborhood Technology was used to measure affordability. It is recommended that housing and transportation costs are mapped separately to give a better indication of the spatial difference of costs across communities. Table 18 provides an overview of dimensions of affordability examined in Hillsborough County, as well as example indicators and performance targets for use in monitoring implications of the regional transportation plan.

Housing is conventionally deemed affordable when it consumes no more than $30 \%$ of household income. Transportation costs are usually the second-largest expense for households. Typically, the combined costs should be $<40 \%$ of total income to be considered affordable. Figure 9 shows the overall $\mathrm{H}+\mathrm{T}$ analysis results in Hillsborough County, highlighting areas where block groups spend more than $77 \%$, or households greater than 1 standard deviation above the county average, of their total income on housing and transportation. These results may overstate the case somewhat, in light of assumptions and limitations of the database. However, 
they do reveal the auto-dependent nature of the region and exemplify both high housing costs in certain downtown neighborhoods, as well as relatively lengthy commutes on average.

While the $\mathrm{H}+\mathrm{T}$ Index is not a measure of equity per se, the analysis can be used to identify COC block groups with housing and transportation costs significantly higher than the countywide average. Furthermore, transportation costs across COC can be mapped using the $\mathrm{H}+\mathrm{T}$ Index, giving an idea of spatial differences in costs across these communities and providing a method of measuring transportation affordability over time (Figure 10).

\section{Table 18: Affordability Measures and Methodology}

\begin{tabular}{|c|c|c|c|c|}
\hline \multirow{2}{*}{$\begin{array}{l}\text { Affordability } \\
\text { Dimension }\end{array}$} & \multirow{2}{*}{ Data Source } & \multirow{2}{*}{ Indicator } & \multicolumn{2}{|c|}{ Example Performance Targets } \\
\hline & & & Countywide & $\begin{array}{l}\text { Communities of } \\
\text { Concern }\end{array}$ \\
\hline $\begin{array}{l}\text { Combined housing } \\
\text { and transportation } \\
\text { costs as a percentage } \\
\text { of household income }\end{array}$ & $\begin{array}{l}\text { Center for } \\
\text { Neighborhood } \\
\text { Technology - } \\
\text { H+T Index } \\
\text { http://htaindex.cnt } \\
\text {.org/ }\end{array}$ & $\begin{array}{l}\text { Block groups with } \\
\text { combined housing } \\
\text { and transportation } \\
\text { costs greater than } 1 \\
\text { standard deviation } \\
\text { above countywide } \\
\text { average (average = } \\
61 \% \text { ). }\end{array}$ & $\begin{array}{l}\text { By 2040, decrease } \\
\text { average household } \\
\text { combined cost of } \\
\text { housing and } \\
\text { transportation by } \\
\text { [25\%] compared to } \\
2014 \text {. }\end{array}$ & $\begin{array}{l}\text { By 2040, decrease the } \\
\text { average cost of } \\
\text { transportation for } \\
\text { communities of } \\
\text { concern by [50\%] } \\
\text { compared to } 2014 \text {. }\end{array}$ \\
\hline $\begin{array}{l}\text { Transportation costs } \\
\text { across COC }\end{array}$ & $\begin{array}{l}\text { Center for } \\
\text { Neighborhood } \\
\text { Technology - } \\
\text { H+T Index } \\
\text { htaindex.cnt.org/ }\end{array}$ & $\begin{array}{l}\text { Range of } \\
\text { transportation costs } \\
\text { across COC. }\end{array}$ & $\begin{array}{l}\text { By 2040, decrease } \\
\text { the average } \\
\text { household costs of } \\
\text { transportation by } \\
\text { [25\%] compared to } \\
2014 \text {. }\end{array}$ & $\begin{array}{l}\text { By 2040, decrease the } \\
\text { average household } \\
\text { cost of transportation } \\
\text { for communities of } \\
\text { concern by [50\%] } \\
\text { compared to } 2014 \text {. }\end{array}$ \\
\hline
\end{tabular}




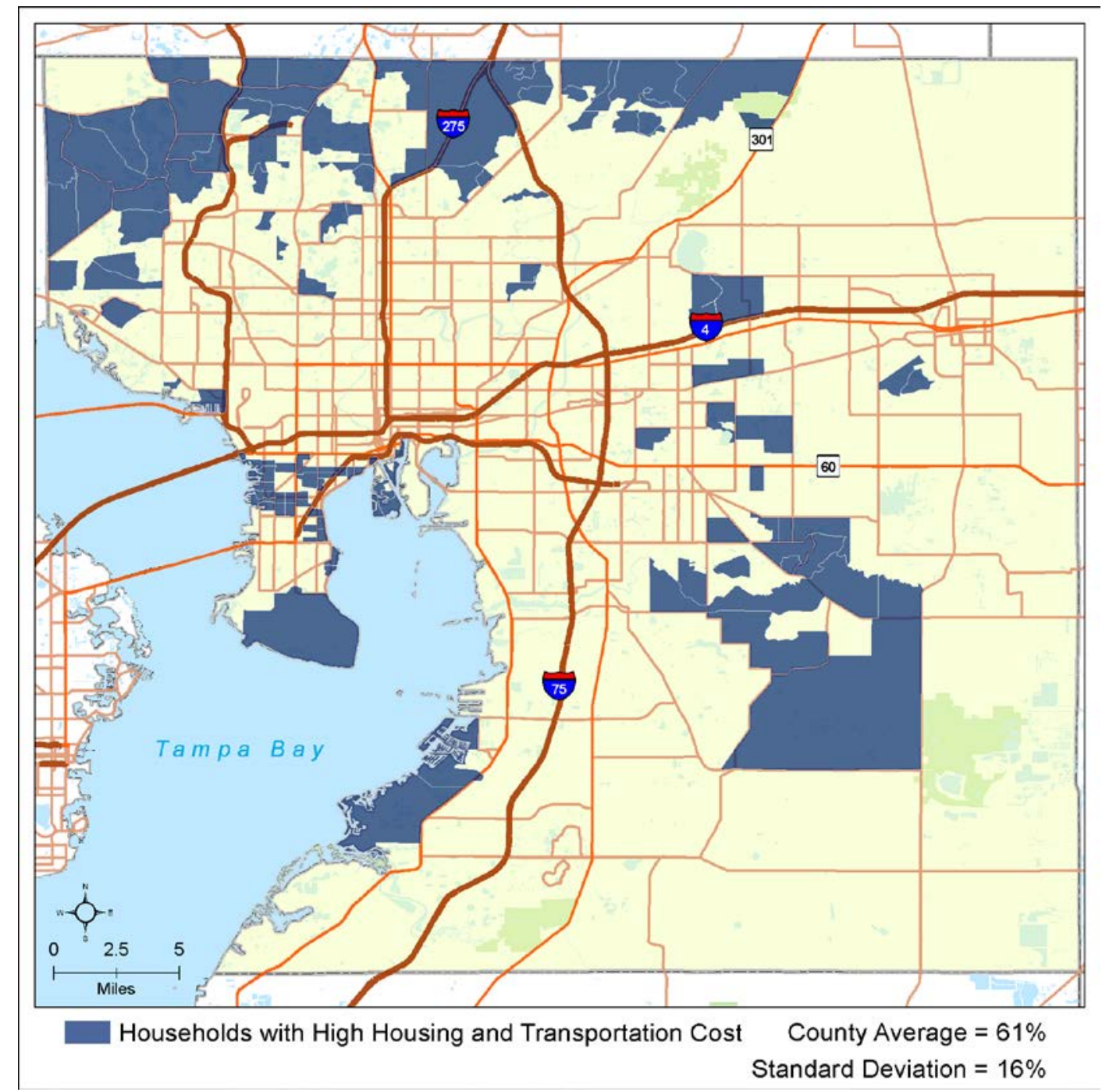

Figure 9: Housing plus transportation affordability in Hillsborough County. 


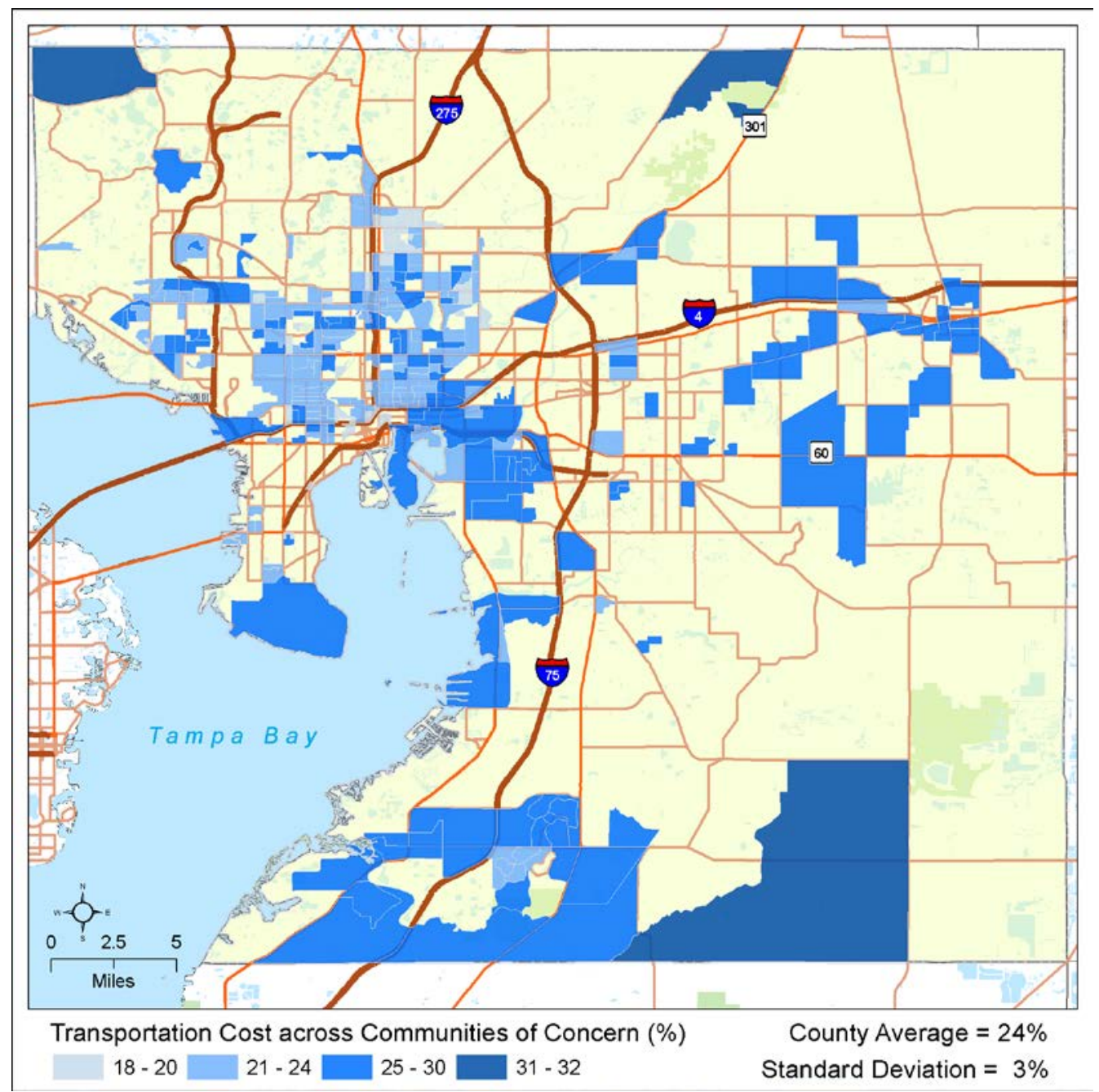

Figure 10: Average transportation costs of communities of concern in Hillsborough County.

\subsubsection{Health and Safety}

A variety of measures of health and safety may be used for regional planning and equity analysis. For this analysis, the research team focused primarily on pedestrian and bicycle per capita crash rates in light of the high levels of bicycle and pedestrian crashes in the Tampa Bay region generally.

Table 19 reviews the measures and methods used to examine bicycle and pedestrian safety in the region, and provides example indicators and performance targets.

The average pedestrian and bicyclist crash rate per capita was calculated countywide, and block groups greater than one standard deviation above the countywide average were identified as having a relatively high crash rate. Block groups that have a high number of pedestrian (Figure 11) and bicycle (Figure 12) crashes per capita and are also COC were identified. 
Table 19: Bicycle and Pedestrian Safety Measures and Methodology

\begin{tabular}{|c|c|c|c|c|}
\hline \multirow{2}{*}{$\begin{array}{l}\text { Health } \\
\text { Dimension }\end{array}$} & \multirow[b]{2}{*}{ Data Source } & \multirow[b]{2}{*}{ Indicators } & \multicolumn{2}{|c|}{ Example Performance Targets } \\
\hline & & & Countywide & $\begin{array}{l}\text { Communities of } \\
\text { Concern }\end{array}$ \\
\hline $\begin{array}{l}\text { Pedestrian } \\
\text { Safety: } \\
\text { Pedestrian crash } \\
\text { rates per capita }\end{array}$ & Hillsborough MPO & $\begin{array}{l}\text { Percentile of per capita } \\
\text { pedestrian crash rate } \\
\text { by block group. COC } \\
\text { within these block } \\
\text { groups are identified. }\end{array}$ & $\begin{array}{l}\text { By } 2040 \text {, decrease } \\
\text { the per capita } \\
\text { pedestrian crash } \\
\text { rate by [50\%] } \\
\text { compared to } 2014 \text {. }\end{array}$ & $\begin{array}{l}\text { By } 2040 \text {, decrease the } \\
\text { per capita pedestrian } \\
\text { crash rate in COC by } \\
\text { [75\%] compared to } \\
2014 \text {. }\end{array}$ \\
\hline $\begin{array}{l}\text { Bicycle Safety: } \\
\text { Bicycle crash } \\
\text { rates per capita }\end{array}$ & Hillsborough MPO & $\begin{array}{l}\text { Percentile of per capita } \\
\text { bicycle crash rate by } \\
\text { block group. COC } \\
\text { within these block } \\
\text { groups are identified. }\end{array}$ & $\begin{array}{l}\text { By } 2040 \text {, decrease } \\
\text { the per capita } \\
\text { bicycle crash rate } \\
\text { by } 50 \% \text { compared } \\
\text { to } 2014 \text {. }\end{array}$ & $\begin{array}{l}\text { By } 2040 \text {, decrease the } \\
\text { per capita bicycle } \\
\text { crash rate in COC by } \\
\text { [75\%] compared to } \\
2014 \text {. }\end{array}$ \\
\hline
\end{tabular}

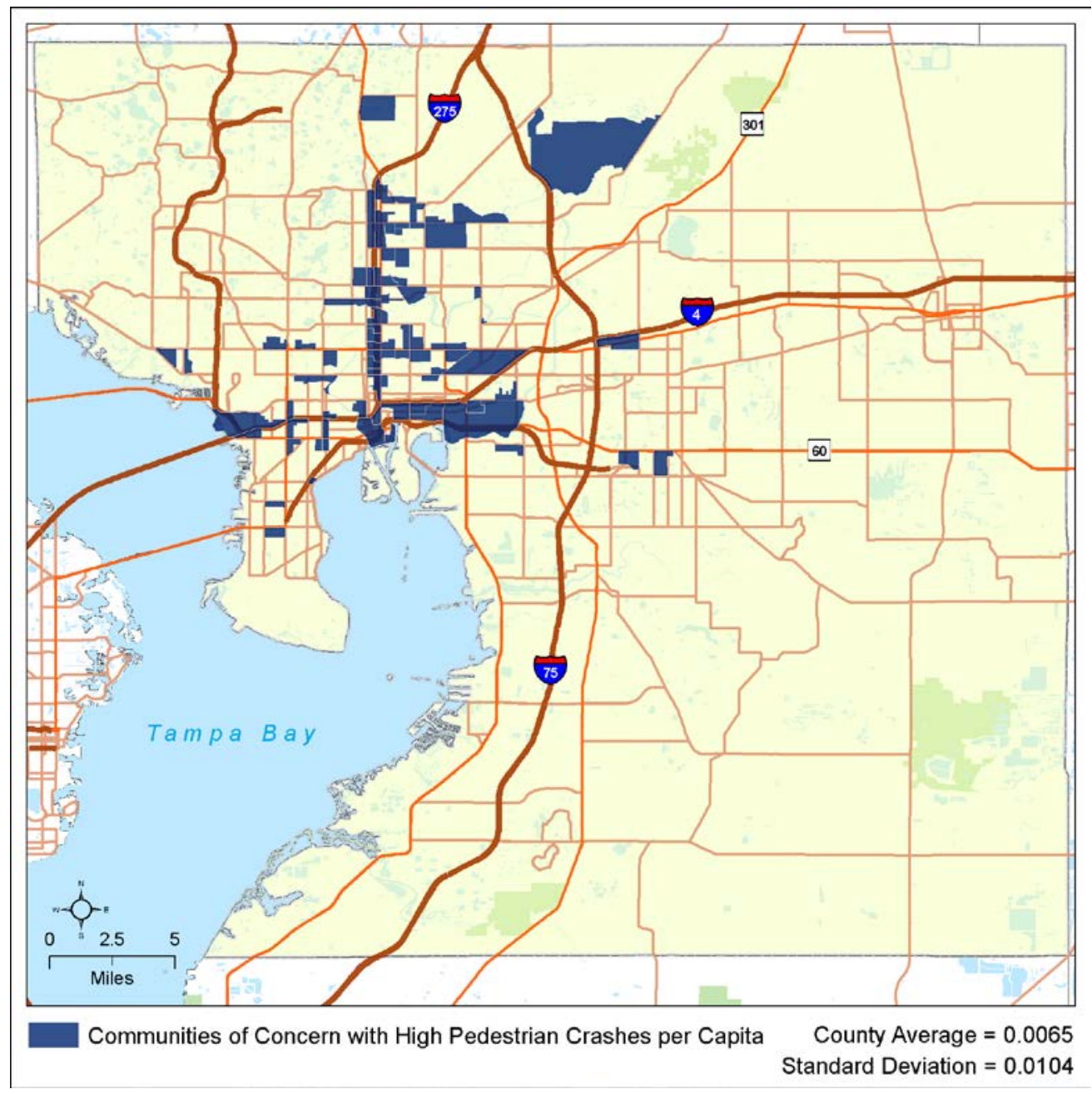

Figure 11: Communities of concern with high pedestrian crashes per capita. 


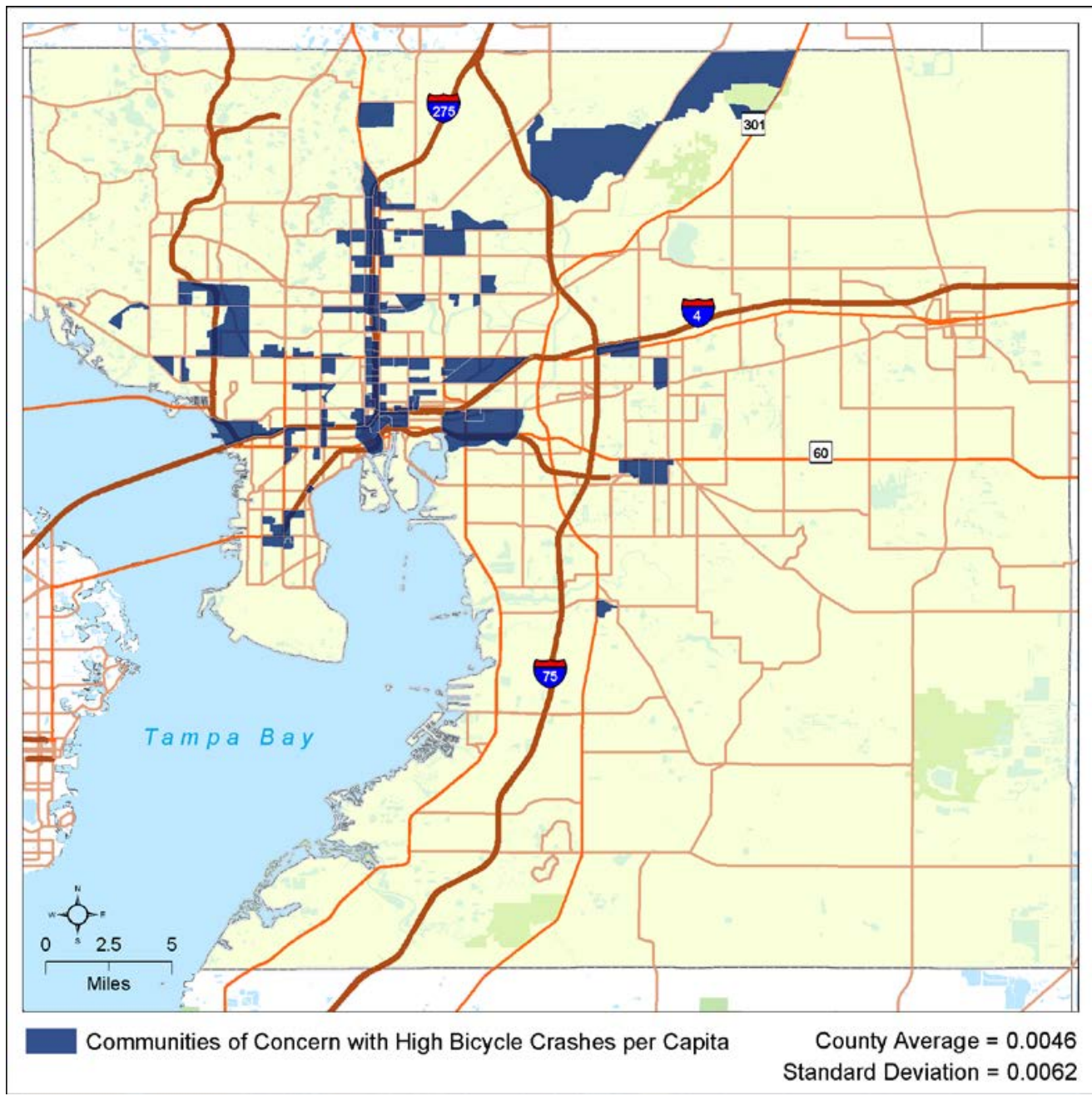

Figure 12: Communities of concern with high bicycle crashes per capita.

\subsubsection{Distributional Equity of Investments}

Total project investment (regardless of type or mode) is a common, but rather weak measure of equity, as projects in an area do not always benefit area COC. It is best to disaggregate project costs by type/mode, and also to prioritize investments that address identified accessibility, affordability and health deficiencies for COC in the project prioritization process.

Table 20 provides a simple example of how one might examine and monitor distributional equity of investments in a region. Per capita investment in COCs is compared to per capita investment in non-COCs as whole, and can be further stratified by the mode or type of investment in that community. For example, per capita safety investments for bicycle facilities can be examined between COCs and non-COCs to determine the distributional equity of investment. Unfortunately, the distributional equity of investments for Hillsborough currently cannot be evaluated using GIS, as the MPO does not currently disaggregate project investment 
data by type and mode. It is recommended that data be disaggregated by type and mode for use in future analysis.

Table 20: Distributional Equity of Investments Measure and Methodology

\begin{tabular}{|c|c|c|c|c|}
\hline \multirow{2}{*}{$\begin{array}{l}\text { Distributional } \\
\text { Dimension }\end{array}$} & \multirow{2}{*}{ Data Source } & \multirow{2}{*}{ Metric } & \multicolumn{2}{|c|}{ Example Performance Targets } \\
\hline & & & Countywide & COCS \\
\hline $\begin{array}{l}\text { Distributional } \\
\text { Equity }\end{array}$ & $\begin{array}{l}\text { MPO } \\
\text { Transportation } \\
\text { Improvement } \\
\text { Program and } \\
\text { LRTP }\end{array}$ & $\begin{array}{l}\text { Proportionate per } \\
\text { capita investment } \\
\text { for COC vs. non- } \\
\text { COC communities, } \\
\text { disaggregated by } \\
\text { project type and } \\
\text { mode. }\end{array}$ & NA & $\begin{array}{l}\text { Increase per capita } \\
\text { investment in deficient } \\
\text { COC areas by } 10 \% \\
\text { annually over } \\
\text { countywide per capita } \\
\text { investment. }\end{array}$ \\
\hline
\end{tabular}

\subsubsection{Conclusions}

As with many MPOs across the nation, the Hillsborough MPO's approach to equity has not been a systematic and integral part of the long-range planning and prioritization process. Rather, efforts to date have been in the context of specific studies and transportationdisadvantaged service planning activities. This study provides the MPO with potential methods and measures for identifying COCs and more systematically monitoring the long-term impacts of the regional plan and projects, using indicators related to affordability, accessibility and safety. Results of the study were presented to various MPO committees and the MPO Board to help inform future planning efforts.

The Hillsborough MPO is now using this equity analysis to screen TIP projects for impacts and benefits to COCs. In particular, the MPO is identifying areas with low access to food and other services, such as healthcare, and using additional tools, such as health impact assessments, to prioritize projects to help COCs facing these challenges. The 2045 update to the MPO Long Range Transportation Plan and Title VI plan will include details from, and expansion of, this equity analysis. Other projects include a recently concluded Transportation Disadvantaged Summit, which brought together providers and recipients to discuss transportation disadvantaged needs. 


\subsection{METRO - PORTLAND, OR}

\subsubsection{Introduction and Background}

The Portland metro area, governed by a unique elected regional government called Oregon Metro, has a population approaching 1.6 million (out of 2.4 million in the greater 7county metropolitan area including parts of southwest Washington State) (Christensen, 2015). The region is located in the shadow of Mount Hood on the banks of the Columbia and Willamette rivers. The largest city is Portland, followed by Gresham, Hillsboro and Beaverton. The Portland metro area grew 1.72 percent from 2014 to 2015, ranking it among the fastestgrowing places in the country (Beebe, 2016). Oregon Metro has prioritized equity as a key planning objective and seeks to engage historically marginalized communities within the region and develop plans that invest more equitably across the region.

Metro has been in the process of developing the 2018 Regional Transportation Plan (RTP) and the 2018-2021 Metropolitan Transportation Investment Program (MTIP). These planning efforts include a robust stakeholder engagement process with a strong emphasis on gathering input from historically marginalized groups such as communities of color and lowerincome residents. The Transportation Equity Working Group is one of several groups that bring together community members, Metro staff, and representatives of other relevant organizations in the public and private sector to evaluate and modify relevant RTP performance targets and system evaluation measures.

Through the current project, Metro and Portland State University partnered to study national best practices for measuring transportation equity in a scenario-planning context and are using them to guide the RTP update and inform the working group. Metro adopted an outcomesbased approach in 2010 with a set of performance targets to measure the progress of implementing the plan. The two equity-oriented performance targets are:

- Affordability. By 2040, reduce the average household combined cost of housing and transportation by 25 percent compared to 2010.

- Access to Daily Needs. By 2040, increase by 50 percent the number of essential destinations accessible within 30 minutes by bicycling and public transit for low-income, minority, senior and disabled populations compared to 2005.

In 2010, the outcomes-based RTP did not establish a formal method to measure and track these equity performance targets and the RTP tasked that effort to future RTP cycles. In the development of the 2014 RTP, forecasting data limitations and a streamlined 2014 RTP process, did not include in the work plan capacity to develop a measurement of the two equity-oriented performance targets. Therefore, the charge of the $2018 \mathrm{RTP}$ update process is to simplify these targets and develop ways to measure successful implementation of the plan over time (Cho, 2016).

\subsubsection{Priority Issues}

A key element of Metro's equity evaluation work has been to measure what historically marginalized communities value. Through an extensive review of previously collected feedback from historically marginalized communities and project-specific community meetings, Metro 
staff and the working group have determined a list of priority issues for long-range transportation planning. These issues included, but are not limited to:

- Housing and transportation affordability

- Access to essential destinations and jobs via automobile and transit

- Distribution of infrastructure investments

- Safety

- Environmental and health impacts of air pollution and environmental degradation

- Gentrification and displacement

\subsubsection{Methodology}

Metro's strategies for distributional equity analysis includes both qualitative and quantitative analysis. Focus groups, surveys and community meetings will provide details and context. Mapping and modeling according to predetermined definitions and thresholds for the locations of historically marginalized communities will be overlaid with the locations of various types of projects and forecastable project impacts. Different RTP scenarios will be compared to the base-year option before a final RTP package is selected. Metro does consider previous inequities and seeks to invest more heavily in those areas going forward. Further details are outlined in the sections that follow.

\subsubsection{Identifying Historically Marginalized Communities}

To determine definitions and thresholds for historically marginalized communities in the region, Metro conducted extensive background research and presented options to the community in an online survey. People of color, those with limited English proficiency, and low-income individuals are required to be considered under Title VI. Metro expanded its scope to include older adults and young persons because of feedback provided during the 2014 RTP and to comply with the Age Discrimination Act of 1975. Metro defines historically marginalized communities as:

- People of Color. Those who identify as any of the following races: Black or African American, American Indian or Alaska Native, Asian, Native Hawaiian or other Pacific Islander, some other race or multiple races AND persons who identify ethnically as Hispanic or Latino in the 2010 U.S. decennial census.

- People with Limited English Proficiency. Persons who identify in the U.S. Census Bureau's American Community Survey as speaking English "less than very well."

- Older adults. Persons who are 65 years of age or older as of the U.S. Census Bureau's 2010 census.

- Young People. Persons who are 17 years of age or younger as of the U.S. Census Bureau's 2010 census.

- People with Low Income. Persons in a household living $200 \%$ of the federal poverty guidelines (2016). 
Metro uses two different thresholds census data - a Tier 1 analysis, and a Tier II Focused Analysis. These thresholds help to define the locations of historically marginalized communities for the assessment. The Tier 1 thresholds vary by community and are as follows:

- People of Color. Census blocks where the total population of people of color (by percent) is greater than the regional rate of people of color population (by percent). The regional rate is estimated at $27 \%$ region-wide.

- People with Limited English Proficiency. Regardless of language, census tracts that have more than an $8.71 \%$ LEP population. The $8.71 \%$ represents the regional rate of over-5 years of age population who "do not speak English very well" regardless of native language.

- Older Adults. Census blocks where the total older adult population (by percent) is greater than the regional rate of older adult population (by percent). The regional rate is estimated at $10.2 \%$.

- Young People. Census blocks where the total young-person population (by percent) is greater than the regional rate of young person population (by percent). The regional rate is estimated at $23 \%$.

- People with Low Income. Census tracts where the total low-income population (by percent) is greater than the regional rate of low-income population (31.8\%).

In addition, by request of the work group, a second demographic evaluation Tier II has been added as part of the assessment to focus more closely on people of color, people with lowerincomes, and limited English proficiency populations. The work group had requested evaluation of areas with high concentrations of these three communities or hidden pockets of language isolation as well. Descriptions of thresholds used to identify these areas are provided in Table 21.

Table 21: Metro Tier II Thresholds for Identifying Historically Marginalized Communities

\begin{tabular}{|l|l|}
\hline \multicolumn{1}{|c|}{$\begin{array}{c}\text { Historically Marginalized } \\
\text { Community }\end{array}$} & \multicolumn{1}{c|}{ Geographic Threshold } \\
\hline People of Color & $\begin{array}{l}\text { Census tracts above the regional rate for people of color } \\
\text { AND census tract has twice }(2 \mathrm{x}) \text { the population density of } \\
\text { the regional average (.48 person per acre). }\end{array}$ \\
\hline Low-Income & $\begin{array}{l}\text { Census tracts above the regional rate for low-income } \\
\text { households AND census tract has twice (2x) the population } \\
\text { density of the regional average (.58 person per acre). }\end{array}$ \\
\hline Limited English Proficiency & $\begin{array}{l}\text { Census tracts above the regional rate for low-income } \\
\text { households AND those census tracts identified as "safe } \\
\text { harbor" tracts for language isolation AND the census tract } \\
\text { has twice (2x) the population density of the regional average } \\
\text { (.15 person per acre) }{ }^{1}\end{array}$ \\
\hline
\end{tabular}

\footnotetext{
${ }^{1}$ Safe harbor, a provision of Title VI, addresses agency language assistance to LEP persons to ensure access to public resources. For analysis, safe harbor may help to identify areas where additional attention is warranted because of a concentration of language isolation. Safe harbor applies when a language isolated group constitutes $5 \%$ or 1,000 persons of the total population in the given area.
} 


\subsubsection{Public Participation}

Metro uses a "wide net” approach to involving stakeholders agency-wide and in each of its long-range transportation plans. Public engagement activities include public comment periods and open, well-publicized meetings to weigh in on proposed policy. The agency also takes a more targeted approach to engaging historically marginalized communities involving language and community-specific workshops held in partnership with community-based organizations.

During the 2014 Regional Transportation Plan, the outreach process involved a public opinion research poll conducted online, five targeted community workshops, including one in Spanish, and events in collaboration with Elders in Action and the Environmental Action Group. Several public comment opportunities were available at different stages in the process. Since the 2014 RTP, Metro had expanded its public participation tools, by more actively utilizing social media, news publications, mailings and its website to circulate information about the process and encourage people to participate.

For the 2018 RTP process, similar techniques are being utilized, with the addition of technical work groups and Regional Leadership Forums. For example, the transportation equity working group is gathering technical and policy input from various stakeholders. The 2018 RTP Regional Leadership Forums are bringing together community leaders to sit at the same table as elected officials having policy discussions related to the 2018 RTP.

\subsubsection{Applications}

\subsubsection{Proposed Equity Measures and Methods}

At the time of this study, methods for analyzing achievement and progress towards the 2018 RTP equity goals were still being developed by Metro and the stakeholder working group. ${ }^{2}$ Research from the PSU NITC grant-funded team was used to identify a longer list of transportation equity system evaluation measures that address the issues identified by historically marginalized communities (information presented in Section 3.0). From that longer list, the proposed equity measures for the 2018 regional plan were developed. Table 22: Proposed Equity Measures for METRO 2018 Regional Transportation Plan lists the system evaluation measures that correspond with identified priority issues and contains a brief description of each of the measures considered for the final plan evaluation.

\footnotetext{
${ }^{2}$ For up to date information about these equity measures and the status of the plan, visit the website for the equity work group: http://www.oregonmetro.gov/public-projects/2018-regional-transportation-plan/equity
} 
Table 22: Proposed Equity Measures for METRO 2018 Regional Transportation Plan ${ }^{3}$

\begin{tabular}{|c|c|}
\hline Measure & Key research questions used to define the measure \\
\hline \multicolumn{2}{|r|}{ Priority: Housing and transportation affordability } \\
\hline $\begin{array}{l}\text { Housing and } \\
\text { Transportation Costs }\end{array}$ & The exact technical definition was not final as of the time of this report \\
\hline \multicolumn{2}{|c|}{ Priority: Access to essential destinations and jobs via automobile and transit } \\
\hline $\begin{array}{l}\text { Access to Jobs by } \\
\text { wage profile }\end{array}$ & $\begin{array}{l}\text { 1) How many low and middle-wage jobs can be reached in a given time window } \\
\text { by different travel modes? } \\
\text { 2) What are differences in low and middle-wage job access for the region and } \\
\text { specifically for historically marginalized communities? } \\
\text { 3) Is the difference in low and middle-wage job access between automobile and } \\
\text { transit? Is there a difference that extends beyond a reasonable threshold and creates } \\
\text { a "transit access disadvantage" to low and middle-wage jobs in certain areas? If so, } \\
\text { do those "transit access disadvantage” areas overlap with areas with high } \\
\text { concentrations of historically marginalized communities? } \\
\text { 4) Is the access to low and middle-wage jobs proportionate, or providing greater } \\
\text { access to jobs, in light of anticipated future population and employment growth? }\end{array}$ \\
\hline $\begin{array}{l}\text { Access to } \\
\text { Community Places }\end{array}$ & $\begin{array}{l}\text { 1) What are the differences between the number of community places accessible } \\
\text { by historically marginalized communities relative to the entire region? Are there } \\
\text { large differences in access seen between travel modes? } \\
\text { 2) Are there significant differences (or lack of differences) seen between } \\
\text { historically marginalized communities and the region once the proposed } \\
\text { transportation investments are added? }\end{array}$ \\
\hline $\begin{array}{l}\text { Access to Travel } \\
\text { Options - } \\
\text { Completeness and } \\
\text { Connectivity of the } \\
\text { Active } \\
\text { Transportation } \\
\text { Network - }\end{array}$ & $\begin{array}{l}\text { 1) How many miles of the regional pedestrian, bicycle, trail and street networks are } \\
\text { completed? How many miles are left to complete? } \\
\text { 2) What percentage of bicycle and pedestrian gaps within } 1 / 2 \text { mile of transit stops } \\
\text { and stations are completed? } \\
\text { 3) Has connectivity and density of the regional walking, bicycling and roadway } \\
\text { networks increased? } \\
\text { 4) What time-frame are the pedestrian, bicycle, trail and new street investments } \\
\text { being proposed for, compared to other investments in the RTP? }\end{array}$ \\
\hline
\end{tabular}

\footnotetext{
${ }^{3}$ Oregon Metro staff memo "2018 RTP System Evaluation Measures Methodologies” Note that "historically marginalized communities" will mean both a tier 1 and tier 2 analysis.
} 
Table 23: Proposed Equity Measures for METRO 2018 Regional Transportation Plan (cont.)

\begin{tabular}{|c|c|}
\hline \multicolumn{2}{|r|}{ Priority: Safety } \\
\hline $\begin{array}{l}\text { Share of safety } \\
\text { projects }\end{array}$ & $\begin{array}{l}\text { 1) How many and what percentage of the region's proposed transportation projects } \\
\text { are identified as safety projects? } \\
\text { 2) What percentage of the total transportation investment package (cost) is } \\
\text { attributed to safety projects? } \\
\text { 3) What percentage of the total number of transportation safety investments are } \\
\text { located in historically marginalized communities/ focused historically } \\
\text { marginalized communities? } \\
\text { 4) Is there a difference of transportation safety investment levels (cost) in areas } \\
\text { with historically marginalized communities/ focused historically marginalized } \\
\text { communities? } \\
\text { 5) What is the per-person expenditure of transportation safety investments region- } \\
\text { wide and for historically marginalized communities/ focused historically } \\
\text { marginalized communities? }\end{array}$ \\
\hline $\begin{array}{l}\text { Exposure to Non- } \\
\text { Interstate Vehicles } \\
\text { Miles Traveled } \\
\text { Exposure }\end{array}$ & $\begin{array}{l}\text { 1) What is the region's vehicle miles traveled (VMT) in each TAZ and how does it } \\
\text { change above a certain threshold with the proposed package of transportation } \\
\text { investments? } \\
\text { 2) Is there a difference in exposure to VMT in TAZ's with high concentrations of } \\
\text { historically marginalized communities? }\end{array}$ \\
\hline Priority: Envi & nmental and health impacts of air pollution and environmental degradation \\
\hline $\begin{array}{l}\text { Intersection of } \\
\text { Transportation } \\
\text { Investments, } \\
\text { Resource Habitats, } \\
\text { and Communities }\end{array}$ & $\begin{array}{l}\text { 1) What percentage of resource habitats overlap with areas with high } \\
\text { concentrations of historically marginalized communities? } \\
\text { 2) Are these resource habitats seeing a greater percentage of proposed roadway } \\
\text { transportation investments that may have a potential conflict with the region's } \\
\text { resource habitats? } \\
\text { 3) Is the percentage in historically marginalized communities greater than the } \\
\text { region? }\end{array}$ \\
\hline
\end{tabular}

\subsubsection{Methods of Analysis}

The equity measures presented in the table above for the 2018 RTP Metro will rely on outputs from both the travel demand model and "off model” inventories and assessment using geographic information systems (GIS). The regional travel model will predict system outcomes such as a total travel (VMT) as well as performance measures like travel times used for the accessibility measures, for example. It can do this for each travel analysis zone and therefore allow measures to differentiate between historically marginalized communities and other geographies. "Off model” measures will inventory and map project counts and funding and project locations and enable an analysis of their impact on historically marginalized communities. All the equity measures, in the end, attempt to compare benefits and burdens on historically marginalized communities with other communities in the region. Where disparities 
appear especially egregious, specific projects can be further investigated to understand if they can be reconfigured to improve equity between communities.

\subsubsection{Conclusions}

The 2014 RTP equity analysis found that Metro is investing at a higher rate in historically marginalized communities in both the short and long term, but recognized there are nuances to those transportation investments and how they truly benefit historically marginalized communities. For the 2018 RTP process, with an outcomes-based emphasis, Metro is developing and testing methods to measure and forecast the benefits and impacts of its short and long-term transportation investments package for historically marginalized groups. 


\subsection{OVERVIEW OF KEY METHODS AND MEASURES}

The major outcomes of this research included a national scan of best practice methods and measures for equity analysis. These findings are provided below to serve as an initial resource to MPOs interested in creating and updating their equity analysis methods. Additional methods for examining accessibility to essential destinations, using GIS and readily available data, are provided in the Hillsborough MPO case study.

\subsection{AFFORDABILITY: HOUSING AND TRANSPORTATION COSTS}

\begin{tabular}{|c|c|}
\hline Measure & Housing plus transportation costs \\
\hline $\begin{array}{l}\text { How it is } \\
\text { calculated }\end{array}$ & $\begin{array}{l}\text { The total housing and transportation costs can consume a substantial } \\
\text { portion of a household budget. A regional plan can affect the availability } \\
\text { and level of service for different transportation modes and thus affect the } \\
\text { way people travel and therefore their cost of travel. Housing costs are } \\
\text { projected using a different model based on projections of housing supply } \\
\text { and demand in each neighborhood. This measure will estimate the total } \\
\text { housing and transportation costs for households living in different } \\
\text { neighborhoods. The measure can be made at the TAZ or block group } \\
\text { scale and so can be used to compare the cost burdens for different } \\
\text { communities. The measure illustrates where investments help to reduce } \\
\text { costs. The measure can be presented as an average cost per household, } \\
\text { cost-saving compared to the base year, or a cost burden (share of } \\
\text { household income). Data is available from the Center for Neighborhood } \\
\text { Technology }\end{array}$ \\
\hline $\begin{array}{l}\text { Why this is an } \\
\text { equity measure }\end{array}$ & $\begin{array}{l}\text { The regional plan will affect how people travel and the cost of that travel } \\
\text { to their household. Different neighborhoods then will experience } \\
\text { different changes in their travel and housing costs. This measure will } \\
\text { compare cost changes between communities. Costs for communities of } \\
\text { concern can be tracked over time. }\end{array}$ \\
\hline Key assumptions & $\begin{array}{l}\text { Housing and transportation costs are estimated based on location, and } \\
\text { thus rely heavily on modeling assumptions about vehicle ownership, } \\
\text { travel mode choice, and housing costs for different neighborhoods. }\end{array}$ \\
\hline $\begin{array}{l}\text { Measurement } \\
\text { type and } \\
\text { timeframe }\end{array}$ & $\begin{array}{l}\text { This measure can be made for any sub-region and relies on modeled } \\
\text { travel data. Because of uncertainties in the housing cost model it may be } \\
\text { best suited over the short term. }\end{array}$ \\
\hline $\begin{array}{l}\text { Special } \\
\text { considerations }\end{array}$ & This is a commonly used measure to understand equity. \\
\hline
\end{tabular}




\subsection{AFFORDABILITY: TRANSPORTATION COSTS}

\begin{tabular}{|l|l|}
\hline Measure & Travel time savings \\
\hline $\begin{array}{l}\text { How it is } \\
\text { calculated }\end{array}$ & $\begin{array}{l}\text { A regional plan can affect the availability and level of service for } \\
\text { different transportation modes and thus affect the speed and travel time } \\
\text { needed for residents to travel throughout the day. These speeds are } \\
\text { modeled and can be translated into a time savings compared to the base } \\
\text { year. So, as transportation investments improve speed, travel times are } \\
\text { reduced. } \\
\text { The measure is made at the TAZ or other sub-region scale and so can be } \\
\text { used to compare the time savings for different communities. The measure } \\
\text { can be presented as time saved per household, compared to the base year. }\end{array}$ \\
\hline $\begin{array}{l}\text { Why this is an } \\
\text { equity measure }\end{array}$ & $\begin{array}{l}\text { This measure will tell us how time savings are distributed among } \\
\text { different communities and allow us to compare communities. }\end{array}$ \\
\hline Key assumptions & None. \\
\hline $\begin{array}{l}\text { Measurement } \\
\text { type and } \\
\text { timeframe }\end{array}$ & $\begin{array}{l}\text { This measure can be made for any sub-region and is made for the future } \\
\text { RTP investment year. This measure relies on modeled travel times in } \\
\text { future years. }\end{array}$ \\
\hline $\begin{array}{l}\text { Special } \\
\text { considerations }\end{array}$ & $\begin{array}{l}\text { Time savings may be problematic because as people move from } \\
\text { automobile to other modes their travel times may increase, even as other } \\
\text { transportation costs decrease. Additionally, this measure prioritizes travel } \\
\text { speed, which may reward investments in roadways and traffic } \\
\text { improvements and that may not correspond with other regional goals. }\end{array}$ \\
\hline
\end{tabular}

\begin{tabular}{|l|l|}
\hline Measure & Transportation costs (travel time plus out-of-pocket costs) \\
\hline $\begin{array}{l}\text { How it is } \\
\text { calculated }\end{array}$ & $\begin{array}{l}\text { This is similar to the previous measure, but here out-of-pocket costs are } \\
\text { added. These include estimates of parking, tolls, transit fare, gasoline or } \\
\text { other costs incurred for each trip. }\end{array}$ \\
\hline $\begin{array}{l}\text { Why this is an } \\
\text { equity measure }\end{array}$ & $\begin{array}{l}\text { The regional plan will make investments that save travelers time, but also } \\
\text { may allow some travelers to switch to lower-cost modes. These time } \\
\text { savings and changes in out-of-pocket costs will vary by neighborhood } \\
\text { depending on the proximity of investments and the changes in travel } \\
\text { choices. This measure will tell us how travel times and out-of-pocket } \\
\text { costs are distributed among different communities and allow us to } \\
\text { compare communities. }\end{array}$ \\
\hline Key assumptions & $\begin{array}{l}\text { This measure relies on modeled travel times in future years, along with } \\
\text { assumptions about future transportation costs like fuel prices and transit } \\
\text { fares. }\end{array}$ \\
\hline $\begin{array}{l}\text { Measurement } \\
\text { type and } \\
\text { timeframe }\end{array}$ & $\begin{array}{l}\text { This measure can be made for any sub-region, and is made for the future } \\
\text { RTP investment year. Since fuel prices and transit fares may be hard to }\end{array}$ \\
\hline
\end{tabular}




\begin{tabular}{|l|l|}
\hline & $\begin{array}{l}\text { predict in the long term, this may be a measure best suited for near-term } \\
\text { evaluations. }\end{array}$ \\
\hline $\begin{array}{l}\text { Special } \\
\text { considerations }\end{array}$ & $\begin{array}{l}\text { Time savings may be problematic because as people move from } \\
\text { automobiles to other modes their travel times may increase, even as other } \\
\text { transportation costs decrease. Additionally, this measure prioritizes travel } \\
\text { speed, which may reward investments in roadways and traffic } \\
\text { improvements and that may not correspond with other regional goals. }\end{array}$ \\
\hline
\end{tabular}

\subsection{ACCESSIBILITY: ACCESS TO PLACES}

\begin{tabular}{|l|l|}
\hline Measure & Access to essential destinations and jobs ${ }^{\mathbf{4}}$ \\
\hline calculated & $\begin{array}{l}\text { Accessibility here is defined as the ability to reach essential destinations } \\
\text { and jobs. The transportation network affords users the ability to move } \\
\text { about in space. Depending on how well the transportation system works, } \\
\text { that person can reach more things within a given time window. } \\
\text { Accessibility calculations sum the total number of destinations reachable } \\
\text { within a given time window. This calculation depends on the mode } \\
\text { chosen and so the measure would need to be presented separately as } \\
\text { access by auto, transit and bike (as these are modeled modes). Typically, } \\
\text { a time window of 30 or 45 minutes is used to represent a typical } \\
\text { commute trip or reasonable amount of time to reach destinations. A set } \\
\text { distance such as one mile or three miles from essential destinations is } \\
\text { also another method. }\end{array}$ \\
\hline $\begin{array}{l}\text { Why this is an } \\
\text { equity measure }\end{array}$ & $\begin{array}{l}\text { Access is the main goal of a land use and transportation system. } \\
\text { Therefore, improvements in access which result from the regional plan } \\
\text { are an important component of the plan's success. Access is improved for } \\
\text { each mode (auto, transit and bike) and thus this measure is calculated } \\
\text { separately for each mode. Similarly, access is improved differently in } \\
\text { different areas depending on the proximity of those areas to investments. } \\
\text { This measure will tell us how improvements in access (for each mode) } \\
\text { are distributed among different communities and allow us to compare } \\
\text { communities. }\end{array}$ \\
\hline Key assumptions & $\begin{array}{l}\text { Destinations just beyond the travel time window or completely out of } \\
\text { reach. (While this is an unrealistic assumption, the measure is easy to } \\
\text { understand when a simple cutoff time is used instead of a decaying } \\
\text { function.) }\end{array}$ \\
\hline
\end{tabular}

\footnotetext{
${ }^{4}$ Academics have worked to improve this measure by varying the travel time window by demographic group according to how the group actually travels. The travel time window is estimated using the actual travel information from a survey of residents. This generally means that low-income households, for example, travel less and are already less accessible to destinations even before investments in the regional plan are made. This would suggest a need for even more investment in low-income communities to overcome the fact that they are already mobility challenged. Unfortunately, the analysis needed to develop these travel time windows is quite complex.
} 


\begin{tabular}{|l|l|}
\hline $\begin{array}{l}\text { Measurement } \\
\text { type and } \\
\text { timeframe }\end{array}$ & $\begin{array}{l}\text { This measure can be made for any TAZ or sub-region, and is made for } \\
\text { the future RTP investment year using modeled travel times and other } \\
\text { methods. }\end{array}$ \\
\hline $\begin{array}{l}\text { Special } \\
\text { considerations }\end{array}$ & $\begin{array}{l}\text { This is a commonly used measure in other regions. While it is sometimes } \\
\text { complicated to understand because each TAZ or sub-region has a } \\
\text { different number of reachable destinations, it may be worth the } \\
\text { complexity. The measure's results will be very sensitive to the length of } \\
\text { the travel time window. }\end{array}$ \\
\hline
\end{tabular}

\begin{tabular}{|c|c|}
\hline Measure & Transit access disadvantage \\
\hline $\begin{array}{l}\text { How it is } \\
\text { calculated }\end{array}$ & $\begin{array}{l}\text { This measure is based on the defining "essential destinations" and } \\
\text { calculating the sum of what is accessible by auto and transit. Here the } \\
\text { transit access number is divided by the auto access number for each TAZ } \\
\text { or sub-region. A low ratio is produced in areas where transit is lacking. } \\
\text { Then we map historically underrepresented communities within those } \\
\text { transit deficient areas. This creates a sub-region of concern in which we } \\
\text { look at RTP investments, or we can measure improvements in access due } \\
\text { to the RTP investments in these areas. }\end{array}$ \\
\hline $\begin{array}{l}\text { Why this is an } \\
\text { equity measure }\end{array}$ & $\begin{array}{l}\text { Access to destinations by public transit is especially important for } \\
\text { households dependent on transit. This measure compares transit access to } \\
\text { auto access and highlights historically underrepresented communities in } \\
\text { areas where transit performs poorly. These areas can be used as sub- } \\
\text { regions for mapping investments or to measure improvements in access } \\
\text { from the RTP investments. This measure will tell us whether } \\
\text { improvements in access by transit are happening in the places where they } \\
\text { are most needed. }\end{array}$ \\
\hline Key assumptions & $\begin{array}{l}\text { Assumptions here are similar to the Access to essential destinations and } \\
\text { jobs measure. Furthermore, we are assuming that transit is especially } \\
\text { important to historically underrepresented communities. }\end{array}$ \\
\hline $\begin{array}{l}\text { Measurement } \\
\text { type and } \\
\text { timeframe }\end{array}$ & $\begin{array}{l}\text { This measure can be made for any sub-region, and can be made for the } \\
\text { base year or future RTP investment year. If used with the base year it can } \\
\text { make a map of the sub-region of concern , which can then be used to } \\
\text { investigate the location of RTP projects or calculate improvements in } \\
\text { access for the future RTP investment year. }\end{array}$ \\
\hline $\begin{array}{l}\text { Special } \\
\text { considerations }\end{array}$ & $\begin{array}{l}\text { This is an important measure as historical patterns illustrate low-income } \\
\text { communities moving to outer areas with less transit access. }\end{array}$ \\
\hline
\end{tabular}




\begin{tabular}{|l|l|}
\hline Measure & Affordable housing in locations of accessibility \\
\hline calculated & $\begin{array}{l}\text { Measuring accessibility near affordable housing is similar to calculating } \\
\text { the essential destination access measure presented above. Here, we } \\
\text { would look at accessibility to essential destinations within a travel time } \\
\text { window from TAZs or sub-regions with good housing affordability. In } \\
\text { essence, housing affordability defines the sub-region. For local access to } \\
\text { nearby services, we could develop a scoring system like bikescore, } \\
\text { transitscore or walkscore. Alternatively, we can measure the amount of } \\
\text { affordable housing in areas known to have good access, for example near } \\
\text { high capacity transit or in job-rich areas (for all jobs or specific job } \\
\text { types), or in areas with good local access (e.g., with high bikescore, } \\
\text { transitscore or walkscore). }\end{array}$ \\
\hline $\begin{array}{l}\text { Why is this an } \\
\text { equity measure }\end{array}$ & $\begin{array}{l}\text { Similar to other access measures, but focuses on affordable housing } \\
\text { instead of specific community characteristics as the comparison } \\
\text { dimension. This measure can be calculated in two ways: measuring } \\
\text { accessibility near affordable housing, or measuring affordable housing } \\
\text { near accessibility. }\end{array}$ \\
\hline Key assumptions & $\begin{array}{l}\text { This measure uses similar assumptions to those used in the essential } \\
\text { destination access measure above. It also assumes we know the location } \\
\text { of affordable housing in the future, which is less reliable. It would also } \\
\text { require an agreed upon definition for affordable housing (renter vs. } \\
\text { owner) }\end{array}$ \\
\hline $\begin{array}{l}\text { Measurement } \\
\text { type and } \\
\text { timeframe }\end{array}$ & $\begin{array}{l}\text { This measure can be made for any sub-region, and is made for the future } \\
\text { RTP investment year. As a mapping exercise it is off-model. }\end{array}$ \\
\hline $\begin{array}{l}\text { Special } \\
\text { considerations }\end{array}$ & \begin{tabular}{l} 
and \\
\hline
\end{tabular} \\
\hline
\end{tabular}

\subsection{ACCESSIBILITY: INFRASTRUCTURE}

\begin{tabular}{|l|l|}
\hline Measure & Intersection of investments with community geographies \\
\hline $\begin{array}{l}\text { How it is } \\
\text { calculated }\end{array}$ & $\begin{array}{l}\text { Projects in the RTP are mapped to show which investments overlap with } \\
\text { our sub-geographies. From there, we could then sum investments as a } \\
\text { total project number or total project value (investment dollars), and } \\
\text { compare these as per capita, or per area. }\end{array}$ \\
\hline $\begin{array}{l}\text { Why this is an } \\
\text { equity measure }\end{array}$ & $\begin{array}{l}\text { This measure identifies and sums investments made in sub-geographies } \\
\text { (containing historically underrepresented communities) and looks at the } \\
\text { level of investment among these communities and the entire region. }\end{array}$ \\
\hline Key assumptions & $\begin{array}{l}\text { The key assumption here is that projects located in a place directly } \\
\text { benefit the people living in that place. }\end{array}$ \\
\hline
\end{tabular}




\begin{tabular}{|l|l|}
\hline $\begin{array}{l}\text { Measurement } \\
\text { type and } \\
\text { timeframe }\end{array}$ & $\begin{array}{l}\text { This measure can be made for any sub-region, and is made for the RTP } \\
\text { investment. As a mapping exercise it is off-model. }\end{array}$ \\
\hline $\begin{array}{l}\text { Special } \\
\text { considerations }\end{array}$ & $\begin{array}{l}\text { This measure is a weak measure of equity because of the assumption that } \\
\text { projects located in an area benefit people living in that area. Typically, } \\
\text { project benefits accrue to those living "downstream" of a project and } \\
\text { having an investment go through a community doesn't necessarily mean } \\
\text { it benefits that community. }\end{array}$ \\
\hline
\end{tabular}

\subsection{TRANSIT: TRANSIT ACCESS}

\begin{tabular}{|c|c|}
\hline Measure & Measures of transit supply \\
\hline $\begin{array}{l}\text { How it is } \\
\text { calculated }\end{array}$ & $\begin{array}{l}\text { There are various measures of transit supply, including total service- } \\
\text { hours or service-miles, or transit vehicle trips within a given timeframe } \\
\text { such as a day, week, month, etc. For the RTP, transit service can be } \\
\text { calculated within sub-geographies and then used to get a per-capita or } \\
\text { per-area measure. }\end{array}$ \\
\hline $\begin{array}{l}\text { Why this is an } \\
\text { equity measure }\end{array}$ & $\begin{array}{l}\text { Transit supply distribution among different communities. For this } \\
\text { measure, therefore, we would look for equal supply per capita, or per } \\
\text { area, for different communities. }\end{array}$ \\
\hline \multicolumn{2}{|l|}{ Key assumptions } \\
\hline $\begin{array}{l}\text { Measurement } \\
\text { type and } \\
\text { timeframe }\end{array}$ & $\begin{array}{l}\text { This measure relies on projections of transit service for the RTP year. It } \\
\text { can be made for any sub-region, and as a mapping exercise it is off- } \\
\text { model. }\end{array}$ \\
\hline $\begin{array}{l}\text { Special } \\
\text { considerations }\end{array}$ & \\
\hline
\end{tabular}

\begin{tabular}{|l|l|}
\hline Measure & Gaps between transit need and supply \\
\hline $\begin{array}{l}\text { How it is } \\
\text { calculated }\end{array}$ & $\begin{array}{l}\text { See the Measures of transit supply measure for a description of } \\
\text { calculation. For transit need, measures typically look at factors such as } \\
\text { vehicle ownership and income to predict transit dependency. A } \\
\text { combination of these factors could be used to create a need index, and } \\
\text { this can be calculated based on existing travel survey data. One can then } \\
\text { calculate the transit supply for high- and low-need areas. }\end{array}$ \\
\hline $\begin{array}{l}\text { Why this is an } \\
\text { equity measure }\end{array}$ & $\begin{array}{l}\text { This measure looks at transit supply distributed towards communities } \\
\text { which need services more than others. For this measure, therefore, we } \\
\text { would look for a match between transit supply and measures of transit } \\
\text { need. }\end{array}$ \\
\hline
\end{tabular}




\begin{tabular}{|l|l|}
\hline Key assumptions & Assumptions about need based on the demographic factors are important. \\
\hline $\begin{array}{l}\text { Measurement } \\
\text { type and } \\
\text { timeframe }\end{array}$ & $\begin{array}{l}\text { This measure relies on projections of transit service and transit need for } \\
\text { the future RTP investment year. It can be made for any sub-region, and } \\
\text { as a mapping exercise it is off-model. }\end{array}$ \\
\hline $\begin{array}{l}\text { Special } \\
\text { considerations }\end{array}$ & \\
\hline
\end{tabular}

\begin{tabular}{|c|c|}
\hline Measure & Gaps between transit need and level of service (LOS) \\
\hline $\begin{array}{l}\text { How it is } \\
\text { calculated }\end{array}$ & $\begin{array}{l}\text { This measure is similar to the Gaps between transit need and supply } \\
\text { measure, except that transit speed or travel times are used instead of } \\
\text { basic measures of supply. Speed or travel times can be calculated from } \\
\text { the transit trips taken from each TAZ for the RTP model. Higher speed, } \\
\text { or lower travel times, would indicate a better performing transit system } \\
\text { for that TAZ. For transit need, measures typically look at factors such as } \\
\text { vehicle ownership and income to predict transit dependency. A } \\
\text { combination of these factors could be used to create a need index, and } \\
\text { this can be calculated based on existing travel survey data. One can then } \\
\text { calculate the transit LOS for high- and low-need areas. }\end{array}$ \\
\hline $\begin{array}{l}\text { Why this is an } \\
\text { equity measure }\end{array}$ & $\begin{array}{l}\text { This measures looks at transit LOS distribution with an emphasis on } \\
\text { communities with higher needs. For this measure, therefore, we would } \\
\text { look for a match between transit LOS and measures of transit need. }\end{array}$ \\
\hline Key assumptions & Assumptions about need based on the demographic factors are important. \\
\hline $\begin{array}{l}\text { Measurement } \\
\text { type and } \\
\text { timeframe }\end{array}$ & $\begin{array}{l}\text { This measure relies on projections of transit service and transit need for } \\
\text { the future RTP investment year. It can be made for any sub-region, and } \\
\text { uses modeled transit LOS. }\end{array}$ \\
\hline $\begin{array}{l}\text { Special } \\
\text { considerations }\end{array}$ & $\begin{array}{l}\text { LOS measure (which reflects service speed) may be problematic because } \\
\text { suburban services may operate at higher speeds but not offer additional } \\
\text { accessibility to destinations. Likewise, core urban services may be slower } \\
\text { but offer better connectivity. Additionally, this measure prioritizes travel } \\
\text { speed, which may reward investments in roadways and traffic } \\
\text { improvements and that may not correspond with other regional goals. }\end{array}$ \\
\hline
\end{tabular}

\begin{tabular}{|l|l|}
\hline Measure & Transit service deficiencies in areas of high need \\
\hline $\begin{array}{l}\text { How it is } \\
\text { calculated }\end{array}$ & $\begin{array}{l}\text { Projections of transit service levels can reveal times of the day or days of } \\
\text { the week when service is minimal or nonexistent for certain TAZs or } \\
\text { sub-regions (for example: hours per week with headways greater or equal } \\
\text { to } 30 \text { minutes). This measure would tally those hours for each TAZ } \\
\text { within sub-geographies. Transit need would be calculated similarly to the } \\
\text { measures Gaps between transit need and supply and Gaps between } \\
\text { transit need and level of service (LOS). Absent or minimal transit }\end{array}$ \\
\hline
\end{tabular}




\begin{tabular}{|l|l|}
\hline & $\begin{array}{l}\text { service can then be calculated for high- and low-need TAZs or sub- } \\
\text { regions to pinpoint where services are needed. }\end{array}$ \\
\hline $\begin{array}{l}\text { Why this is an } \\
\text { equity measure }\end{array}$ & $\begin{array}{l}\text { Variations, especially major absences, in transit services can be harmful } \\
\text { to transit-dependent populations. Investments to reduce the amount of } \\
\text { time where transit services are minimal or absent will support } \\
\text { populations who use transit. Thus, reductions in gaps and improvements } \\
\text { in off-peak service will be important to measure. }\end{array}$ \\
\hline Key assumptions & None. \\
\hline $\begin{array}{l}\text { Measurement } \\
\text { type and } \\
\text { timeframe }\end{array}$ & $\begin{array}{l}\text { This measure relies on projections of transit service for the future RTP } \\
\text { investment year. It can be made for any sub-region, and uses mapped } \\
\text { service projections which are off-model. }\end{array}$ \\
\hline $\begin{array}{l}\text { Special } \\
\text { considerations }\end{array}$ & \\
\hline
\end{tabular}

\subsection{SAFETY: INFRASTRUCTURE / DISPARITIES}

\begin{tabular}{|l|l|}
\hline Measure & Safety-related project locations \\
\hline $\begin{array}{l}\text { How it is } \\
\text { calculated }\end{array}$ & $\begin{array}{l}\text { Safety-related projects in the RTP are mapped to show which } \\
\text { investments overlap with our sub-geographies. From there, we could then } \\
\text { sum investments as a total project number or total project value (in terms } \\
\text { of investment dollars), and compare these as per capita, or per area. }\end{array}$ \\
\hline $\begin{array}{l}\text { Why this is an } \\
\text { equity measure }\end{array}$ & $\begin{array}{l}\text { This measure would look at the distribution of safety-related investments } \\
\text { among different communities. }\end{array}$ \\
\hline Key assumptions & $\begin{array}{l}\text { The key assumption here is that projects located in a place directly } \\
\text { benefit the people living in that place. }\end{array}$ \\
\hline $\begin{array}{l}\text { Measurement } \\
\text { type and } \\
\text { timeframe }\end{array}$ & $\begin{array}{l}\text { This measure can be made for any sub-region, and is made for the future } \\
\text { RTP investment. As a mapping exercise it is off-model. }\end{array}$ \\
\hline $\begin{array}{l}\text { Special } \\
\text { considerations }\end{array}$ & $\begin{array}{l}\text { Safety-related projects probably do correspond with local benefits better } \\
\text { than general transportation investments (an issue mentioned in an earlier } \\
\text { mapping- based measure above). The question here, however, is what is a } \\
\text { fair distribution of safety improvements? Do communities which } \\
\text { typically experience higher traffic danger burdens deserve more } \\
\text { investment? These questions should be addressed alongside the choice } \\
\text { between a per capita or per area measure. }\end{array}$ \\
\hline
\end{tabular}

\begin{tabular}{|l|l|}
\hline Measure & Safety investments on the high-injury network
\end{tabular}




\begin{tabular}{|l|l|}
\hline $\begin{array}{l}\text { How it is } \\
\text { calculated }\end{array}$ & $\begin{array}{l}\text { Safety-related projects in the RTP are mapped to show which } \\
\text { investments overlap with the high-injury network. This would create } \\
\text { some kind of proportional measure where higher proportions of projects } \\
\text { in high-injury locations are better. }\end{array}$ \\
\hline $\begin{array}{l}\text { Why this is an } \\
\text { equity measure }\end{array}$ & $\begin{array}{l}\text { This measure would look at safety-related investments on the high-injury } \\
\text { network. The measure would compare this rate of investment with the } \\
\text { rate of investment overall. Presumably the investment in the high-injury } \\
\text { network would be higher than the average investment overall. Particular } \\
\text { focus is on high-injury network investments that correspond to locations } \\
\text { of importance to historically underrepresented communities. }\end{array}$ \\
\hline $\begin{array}{l}\text { Key assumptions } \\
\text { Measurement } \\
\text { type and } \\
\text { timeframe }\end{array}$ & $\begin{array}{l}\text { We assume that historically underrepresented communities travel often in } \\
\text { high-injury parts of the network. } \\
\text { exercise it is off-model. }\end{array}$ \\
\hline $\begin{array}{l}\text { Special } \\
\text { considerations }\end{array}$ & \\
\hline
\end{tabular}

\begin{tabular}{|l|l|}
\hline Measure & Safe Routes to School (SRTS) investments \\
\hline $\begin{array}{l}\text { How it is } \\
\text { calculated }\end{array}$ & $\begin{array}{l}\text { This measure identifies and sums SRTS investments made in sub-regions } \\
\text { or, alternatively, schools with high representation of low-income students } \\
\text { (with high representation of students who qualify for meal assistance) } \\
\text { We could then compare overall investment (per school or per pupil) } \\
\text { between the schools and all schools. }\end{array}$ \\
\hline $\begin{array}{l}\text { Why this is an } \\
\text { equity measure }\end{array}$ & $\begin{array}{l}\text { The measure would compare this rate of investment in schools of } \\
\text { concern with the rate of investment overall. }\end{array}$ \\
\hline $\begin{array}{l}\text { Key assumptions } \\
\text { Measurement } \\
\text { type and } \\
\text { timeframe }\end{array}$ & $\begin{array}{l}\text { This measure assumes we have an accurate inventory of SRTS } \\
\text { investments into the future. }\end{array}$ \\
\hline $\begin{array}{l}\text { Special } \\
\text { considerations } \\
\text { mode for the future RTP investment. As a mapping exercise it is off- }\end{array}$ \\
\hline
\end{tabular}

\subsection{SAFETY: EXPOSURE}

\begin{tabular}{|l|l|}
\hline Measure & $\begin{array}{l}\text { Total Vehicle Miles Traveled (VMT)/square mile in residential and } \\
\text { commercial areas }\end{array}$ \\
\hline
\end{tabular}




\begin{tabular}{|l|l|}
\hline $\begin{array}{l}\text { How it is } \\
\text { calculated }\end{array}$ & $\begin{array}{l}\text { All vehicle travel (measured as vehicle-miles traveled (VMT)) is } \\
\text { modeled for the RTP and can be summed within any given TAZ or sub- } \\
\text { region. This VMT per square mile is calculated for the sub-region and } \\
\text { compared with the measure for the rest of the region and for future RTP } \\
\text { investment years. }\end{array}$ \\
\hline $\begin{array}{l}\text { Why this is an } \\
\text { equity measure }\end{array}$ & $\begin{array}{l}\text { This measure would look at VMT exposure by particular communities } \\
\text { and how that may change with future RTP investments. It would allow us } \\
\text { to identify areas with a much higher exposure than others. }\end{array}$ \\
\hline Key assumptions & VMT is a proxy for traffic danger and emissions exposure. \\
\hline $\begin{array}{l}\text { Measurement } \\
\text { type and } \\
\text { timeframe }\end{array}$ & $\begin{array}{l}\text { This measure can be made for any sub-region, and is made for the future } \\
\text { RTP investment year. This measure relies on modeled travel data. }\end{array}$ \\
\hline $\begin{array}{l}\text { Special } \\
\text { considerations }\end{array}$ & \\
\hline
\end{tabular}

\subsection{PUBLIC HEALTH: ENVIRONMENTAL AND HEALTH IMPACTS}

\begin{tabular}{|l|l|}
\hline Measure & Proximity to roadways \\
\hline $\begin{array}{l}\text { How it is } \\
\text { calculated }\end{array}$ & $\begin{array}{l}\text { This measure calculates the share of housing within a certain distance } \\
\text { buffer from high-volume roadways which is affordable. Using a mapping } \\
\text { tool, affordable housing resources and all housing resources within } \\
\text { distance buffers (e.g., 500 feet) of high-volume roadways are summed. } \\
\text { This is used to create a share of housing which is affordable within these } \\
\text { buffers. }\end{array}$ \\
\hline $\begin{array}{l}\text { Why this is an } \\
\text { equity measure }\end{array}$ & $\begin{array}{l}\text { The share of housing which is affordable within this distance buffer } \\
\text { should be similar to the share of other housing. An overrepresentation of } \\
\text { affordable housing means that those households are overburdened with } \\
\text { exposure to the impacts of roadways. }\end{array}$ \\
\hline Key assumptions & Proximity to high-volume roadways is proxy for emissions exposure. \\
\hline $\begin{array}{l}\text { Measurement } \\
\text { type and } \\
\text { timeframe }\end{array}$ & $\begin{array}{l}\text { This measure is made for the future RTP investment year, and as a } \\
\text { mapping exercise is off-model. }\end{array}$ \\
\hline $\begin{array}{l}\text { Special } \\
\text { considerations }\end{array}$ & $\begin{array}{l}\text { The buffer distance and the definition of "high-volume" will be } \\
\text { important for this measure. The definition of affordable housing will also } \\
\text { be important for this measure. }\end{array}$ \\
\hline
\end{tabular}




\begin{tabular}{|c|c|}
\hline Measure & Measures of active travel \\
\hline $\begin{array}{l}\text { How it is } \\
\text { calculated }\end{array}$ & $\begin{array}{l}\text { The regional model will predict non-motorized travel mode share, and } \\
\text { this can be modeled for any sub-region and compared with the rest of the } \\
\text { region. }\end{array}$ \\
\hline $\begin{array}{l}\text { Why this is an } \\
\text { equity measure }\end{array}$ & $\begin{array}{l}\text { The choice of non-motorized travel (walking or cycling) is assumed to be } \\
\text { a benefit of RTP investments. Thus, increases in non-motorized travel } \\
\text { should be shared equally between communities if the RTP is equitable. }\end{array}$ \\
\hline \multicolumn{2}{|l|}{ Key assumptions } \\
\hline $\begin{array}{l}\text { Measurement } \\
\text { type and } \\
\text { timeframe }\end{array}$ & $\begin{array}{l}\text { This measure can be made for any sub-region, and is made for the future } \\
\text { RTP investment year. This measure relies on modeled travel data. }\end{array}$ \\
\hline $\begin{array}{l}\text { Special } \\
\text { considerations }\end{array}$ & $\begin{array}{l}\text { While non-motorized travel is held up as a benefit of progressive } \\
\text { planning, many transportation-disadvantaged communities bike and walk } \\
\text { not out of choice but out of necessity. This measure may overstate the } \\
\text { benefits of increases in non-motorized travel in some communities. }\end{array}$ \\
\hline
\end{tabular}

\subsection{OTHER: TIMING OF INVESTMENTS}

\begin{tabular}{|l|l|}
\hline Measure & Displacement risk \\
\hline $\begin{array}{l}\text { How it is } \\
\text { calculated }\end{array}$ & $\begin{array}{l}\text { The RTP investments would be phased into several periods, and the } \\
\text { distribution of these projects in each phase would be mapped. The } \\
\text { projects in sub-geographies would then be summed, and a share of the } \\
\text { total would be calculated to confirm that all communities are receiving } \\
\text { some projects during all phases of the RTP. }\end{array}$ \\
\hline $\begin{array}{l}\text { Why this is an } \\
\text { equity measure }\end{array}$ & $\begin{array}{l}\text { Look at the share of investment during the initial stages of the RTP in } \\
\text { historically underrepresented communities. }\end{array}$ \\
\hline Key assumptions & Timeframe of when an RTP investment plans for its completion. \\
\hline $\begin{array}{l}\text { Measurement } \\
\text { type and } \\
\text { timeframe }\end{array}$ & $\begin{array}{l}\text { This is a mapping exercise and would not involve the model. The } \\
\text { timeframe would depend on the phasing used in the measurement and } \\
\text { what is indicated as the timeframe of when an individual project is } \\
\text { completed. }\end{array}$ \\
\hline $\begin{array}{l}\text { Special } \\
\text { considerations }\end{array}$ & \multicolumn{2}{|l}{} \\
\hline
\end{tabular}




\subsection{MONITORING}

\begin{tabular}{|l|l|}
\hline Measure & Displacement risk \\
\hline $\begin{array}{l}\text { How it is } \\
\text { calculated }\end{array}$ & $\begin{array}{l}\text { There are various types of displacement risk estimations. Most measure } \\
\text { compounding factors of housing cost burden, rapid increases in housing } \\
\text { prices and rents, and the percent of area residents who rent, among other } \\
\text { things. The risk can be calculated for a specific TAZ or sub-region and } \\
\text { can be mapped. RTP projects can then be mapped for their } \\
\text { correspondence with high displacement-risk areas to signal the need for } \\
\text { more attention in those areas. }\end{array}$ \\
\hline $\begin{array}{l}\text { Why this is an } \\
\text { equity measure }\end{array}$ & $\begin{array}{l}\text { Low-income renting populations struggle to remain in areas of the region } \\
\text { where rents and sale prices increase rapidly. Measuring displacement risk } \\
\text { can inform which investments are in need of additional housing strategies } \\
\text { in order to preempt situations where RTP investments could exacerbate } \\
\text { existing displacement risks. }\end{array}$ \\
\hline Key assumptions & $\begin{array}{l}\text { The current geography of displacement risk remains relevant out to the } \\
\text { future RTP investment year. }\end{array}$ \\
\hline $\begin{array}{l}\text { Measurement } \\
\text { type and } \\
\text { timeframe }\end{array}$ & $\begin{array}{l}\text { This measure relies on projections of the factors which predict } \\
\text { displacement risk. These may be less robust out to the future RTP } \\
\text { investment year and better as a short-term monitoring measure. }\end{array}$ \\
\hline $\begin{array}{l}\text { Special } \\
\text { considerations }\end{array}$ & \\
\hline
\end{tabular}

\subsection{CONCLUSIONS}

Despite widespread evidence that MPOs are working towards achieving greater equity in regional transportation planning, the lack of clear guidance has led to a patchwork of approaches. In addition, the role of equity analysis in shaping long-range transportation plans and project decisions is often unclear. A more systematic approach to equity in regional transportation planning would not only benefit historically disadvantaged communities. It can lead to a more holistic and comprehensive approach to regional transportation planning that enhances livability, affordability and economic opportunity for the broader population.

Our research found that efforts have gone into better understanding and mapping lowincome and minority communities and other communities for whom transportation is a challenge, or those who have been historically excluded from the planning process. Locating and reaching out to these communities of concern is a powerful first step for planning agencies attempting to proactively address equity issues in the planning process.

With advancements in data and mapping techniques, new approaches to evaluating distributional outcomes of plans have also been developed in the consulting and academic communities. These have focused on the performance of the systems in terms of accessibility 
and travel times, as well as burden such as air pollution and safety risk. A diverse set of accessibility measures is being used to understand how investments in both transit and roadways increases access to important destinations.

Much of the work we reviewed also recognized that transportation is a significant cost and, along with housing, constitutes a significant financial burden for households. The development of housing and transportation cost measures helps to illustrate how transportation planning can sometimes overlook location efficiency, and that sometimes higher housing costs in high-access areas can be a worthwhile tradeoff. This recognizes that affordable housing near transportation facilities will be an important part of lowering household transportation costs and addressing equity issues. Measures of transportation and housing costs were found to be increasingly important parts of equity analyses across the country.

Alongside advancements in equity analysis, it is vital that affected communities are brought to the table to develop a shared understanding of the key issues, opportunities and project needs illuminated by the analysis. This will help to ensure that project identification and performance monitoring more directly aligns with community needs. The two case studies presented here, while in very different contexts, illustrate the importance of engagement and understanding community needs. They also illustrate how equity analysis can help uncover important community transportation needs that may otherwise be overlooked in long-range planning and investment decisions. 


\subsection{APPENDIX A: SELECTED EXAMPLES}

\subsection{SAN FRANCISCO BAY AREA MTC}

\section{Identifying Communities of Concern}

The Association of Bay Area Governments and the Metropolitan Transportation Commission (MTC) of the San Francisco Bay Area utilized census tracts and transportation analysis zones (TAZ) that had either significant concentrations of both low-income and minority residents or had significant concentrations of any four or more of the following:

- Minority or low-income individuals below $200 \%$ of the federal poverty level

- Persons with limited English proficiency (LEP)

- Zero-vehicle households

- Seniors ages 75 or older

- Individuals with a disability

- $\quad$ Single-parent families

- Housing units occupied by renters who spent $50 \%$ or more of household income on rent

Minorities were defined as individuals who identified as: Black, Hispanic, Asian, American Indian, and/or Alaskan Native. Using these definitions and comparing against regional averages, it was determined that $20 \%$ of the region's population resides in a community of concern (MTC, 2013).

\section{Determining Project Needs}

The MTC adopted the Public Participation Plan in December of 2010, which was used to guide agency outreach and public involvement efforts throughout the development of the MTC/ABAG plan for the San Francisco Bay Area. The Public Participation Plan included three rounds of equity analysis to incorporate equity considerations throughout the development of the plan and two rounds of outreach to low-income communities, minority communities and other underrepresented communities through partnerships with community-based groups and organizations. Stakeholder input was also gathered through the Regional Equity Working Group, which brought together representatives for disadvantaged communities and other agencies and organizations.

In addition to the Public Participation Plan and the Regional Equity Working Group, the MTC utilized its Community-Based Transportation Planning program to identify the transportation needs of low-income communities by involving residents, community and faithbased organizations, transit operators, and county congestion management agencies with the MTC. The information gathered was used to identify the needs of low-income, minority and underserved communities, set priorities, and evaluate options for filling gaps in the transportation system (MTC, 2013). 


\section{Methods for Evaluating Equity}

Table A-1. Methods for Evaluating Equity in the Bay Area

\begin{tabular}{|l|l|}
\hline \multicolumn{1}{|c|}{ Measures } & \multicolumn{1}{c|}{ Methods } \\
\hline $\begin{array}{l}\text { Transportation } \\
\text { Investment } \\
\text { (p. 78) }\end{array}$ & $\begin{array}{l}\text { Population/Use-Based Analysis, Project Mapping, } \\
\text { and Title VI Analysis }\end{array}$ \\
\hline $\begin{array}{l}\text { Housing and } \\
\text { Transportation } \\
\begin{array}{l}\text { Affordability } \\
\text { (p. 85) }\end{array}\end{array}$ & $\begin{array}{l}\text { Commissioned the Center for Neighborhood Technology to study the current } \\
\text { landscape of housing and transportation tradeoffs by the region's low- and moderate- } \\
\text { income households in depth. Basic measure represents housing and transportation } \\
\text { combined as a percentage of household income. }\end{array}$ \\
\hline $\begin{array}{l}\text { Risk of } \\
\text { Displacement } \\
\text { (p. 88) }\end{array}$ & $\begin{array}{l}\text { Overlays households spending 50\% or more of income on rent with locations where } \\
\text { intensive housing growth is planned by 2040. }\end{array}$ \\
\hline $\begin{array}{l}\text { VMT and } \\
\text { Emissions } \\
\text { Density } \\
\text { (p. 91) }\end{array}$ & $\begin{array}{l}\text { Measure of total vehicle miles traveled on major roadways within 1,000 feet of } \\
\text { commercial and residential areas; measures of specific types of emissions are also } \\
\text { utilized. }\end{array}$ \\
\hline $\begin{array}{l}\text { Commute } \\
\text { Time } \\
\text { (p. 99) }\end{array}$ & $\begin{array}{l}\text { Measurement of average travel time per commute trip accounting for all modes based } \\
\text { on the location of an individual's residence, location of employment and travel mode. } \\
\text { Measurements were taken to calculate the average commute time by community type } \\
\text { and by density level. }\end{array}$ \\
\hline \begin{tabular}{l} 
Non- $\begin{array}{l}\text { Commute } \\
\text { Time } \\
\text { (p. 102) }\end{array}$ \\
\hline $\begin{array}{l}\text { Data sources: } \\
\text { Public Use Microdata Sample 1-Year Estimates }\end{array}$ \\
\hline
\end{tabular}$\quad \begin{array}{l}\text { Intended to be a measure of overall equitable mobility; measures average non- } \\
\text { commute travel time by community type (Communities of Concern vs. Remainder of } \\
\text { the Region). }\end{array}$ \\
\hline
\end{tabular}

\section{Methods of Analysis}

The Equity Analysis Report of Plan Bay Area includes three "distinct but related” analyses of the Plan Bay Area draft. These methodologies were designed with input from the Regional Equity Working group as well as stakeholders in the plan. These analyses include a Title VI analysis; an environmental justice analysis, which modeled performance measures to determine if the draft had any disproportionately adverse effects on communities of concern and low-income and minority populations; and an equity analysis to examine the distribution of benefits and burdens between the communities of concern and the region as a whole (MTC, 2013).

In addition to the three above analyses, the report also developed a Transportation Investment Analysis, which utilized the population/use-based analysis and the project mapping analysis to measure the distribution of proposed RTP investments relative to identified communities of concern and low-income populations.

Finally, the methodology of the report included Technical Performance Measures comprised of a set of five measures (in the table above): Housing and Transportation Affordability, Potential for Displacement, Density of Vehicle Travel, Average Commute Time, and Average Non-Commute Time. 


\section{References}

Association of Bay Area Governments, the Metropolitan Transportation Commission. (2013, July). Bay Area Plan: A Strategy for a Sustainable Region. Equity Analysis Report Including Title VI, Environmental Justice and Equity Analysis for Plan Bay Area. Retrieved from http://mtc.ca.gov/sites/default/files/A04_FINAL_PBA_Equity_Analysis_Report.pdf.

\subsection{ATLANTA REGIONAL COMMISSION}

\section{Identifying Communities of Concern}

As noted within its Appendix C-3 document (2011), the Atlanta Regional Commission (ARC) created an Equitable Target Area (ETA) in order to identify its EJ communities. Using census tract-level aggregated data based on SF3 data tables from 2005-2009 American Community Surveys (ACS), it based its index on the following five parameters (Appendix C-3, 2011, p.1):

- $\quad$ Age (Persons $\geq 65$ years old)

- Education (Persons $\geq 25$ years old with no H.S. degree)

- Median housing values

- Poverty rates (thresholds based on the size and composition of the household)

- $\quad$ Race (minorities)

Using the raw data from the ACS in Excel, regional averages were calculated for each of the five parameters as well as parameter categories (Appendix C-3, 2011). Each parameter was broken down into four categories using the following matrix (Appendix C-3, 2011:

- $\quad$ One category = Below average areas for that parameter $=$ Low EJ concern

- $\quad$ The three other categories $=$ Above average areas $=$ Increasing levels of EJ concern

A range for the four categories was created, and using GIS each of the five parameters were mapped out based on their regional averages and their calculated categories (Appendix C-3, 2011). The ETA was then calculated in Excel using a series of calculations in Excel, detailed within Appendix C-3, and then mapped using GIS again (2011).

Within Appendix C-3 (2011), the ARC listed two other methodologies that they used to measure and locate other EJ populations (not included within their ETA Index), such as limited English proficiency (LEP) and disabled populations.

\section{Determining Project Needs}

The ARC Public Participation Plan set forth strategies to obtain public input on equity issues in the area and to determine project needs (ARC, 2011). These strategies included in-person and online public meetings with the ARC Board and Committee, neighborhood forums, stakeholder group discussions and listening sessions, focus group workshops, polls or surveys, and input from a Social Equity Advisory Committee. The public input obtained was compared against issues already scheduled to be addressed by Plan 2040 and Fifty Forward, a document that included the vision for the region for the next 50 years. This was to ensure that all communities 
were involved in the process, and diverse needs, concerns, values and desires were documented and were scheduled to be addressed in the next plan(s).

\section{Measures and Methods of Analysis for Evaluating Equity}

The ARC measured the impact of the implementation of Plan 2040 on ETA communities by measuring the following (Table A-2).

Table A-2. Measures and Methods of Analysis for Evaluating Equity in the Atlanta Region

\begin{tabular}{|c|c|}
\hline Measures & Methods \\
\hline $\begin{array}{l}\text { Zero-Car } \\
\text { Households } \\
\text { (Appendix C-3, } \\
\text { 2011, p. 4) }\end{array}$ & $\begin{array}{l}\text { The distribution of zero-car households in } 2010 \text { vs. } 2040 \text { was calculated, mapped in } \\
\text { GIS, and overlaid on the ETA Index map. The percentage of zero-car households } \\
\text { within ETA communities was calculated and compared using GIS. }\end{array}$ \\
\hline $\begin{array}{l}\text { Accessibility } \\
\text { (Appendix C-3, } \\
\text { 2011, p. 5) }\end{array}$ & $\begin{array}{l}\text { A composite multimodal accessibility (MMA) measure was calculated for each } \\
\text { TAZ that measured ability to access employment centers by } 15 \text { minutes of walking, } \\
30 \text { minutes of driving, or } 45 \text { minutes via local transit within the region for both } \\
2010 \text { and 2040. High or medium-high MMA areas offer all three options and low or } \\
\text { very low MMA areas require driving. The percentage of ETA communities located } \\
\text { in high-accessibility areas was determined using GIS. }\end{array}$ \\
\hline $\begin{array}{l}\text { Unified Growth } \\
\text { Policy Map } \\
\text { (UGPM) } \\
\text { (Appendix C-3, } \\
\text { 2011, p. 5) }\end{array}$ & $\begin{array}{l}\text { The impact of the UGPM on ETA communities was measured by overlaying its } \\
\text { elements on top of identified ETA communities using GIS. Regional and local } \\
\text { centers identified in the Plan } 2040 \text { were also overlaid, and using GIS analysis the } \\
\text { percentage of these centers that were located within their ETA communities was } \\
\text { determined. }\end{array}$ \\
\hline $\begin{array}{l}\text { Transportation } \\
\text { Investments } \\
\text { (Appendix C-3, } \\
\text { 2011, p. 5) }\end{array}$ & $\begin{array}{l}\text { Project shapefiles for planned transportation investments by mode were overlaid on } \\
\text { the identified ETA communities using GIS. A comparison of the proportionate per } \\
\text { capita investment by total projects and project type/mode was calculated for ETA } \\
\text { vs. non-ETA communities using GIS. }\end{array}$ \\
\hline $\begin{array}{l}\text { Jobs-Housing } \\
\text { Balance } \\
\text { (Appendix C-3, } \\
\text { 2011, p. 6) }\end{array}$ & $\begin{array}{l}\text { Examines change in the jobs-housing balance between } 2010 \text { and } 2040 \text {. ARC } \\
\text { population and employment estimates and forecasts were used to calculate the total } \\
\text { number of jobs and households by TAZ. Using Excel, the balance for each TAZ } \\
\text { was calculated and linked to corresponding layers in GIS. GIS analysis was used to } \\
\text { create ratios between ETA vs. non-ETA communities for both years. }\end{array}$ \\
\hline $\begin{array}{l}\text { Livable Centers } \\
\text { Initiative (LCI) } \\
\text { Projects } \\
\text { (Appendix C-3, } \\
\text { 2011, p. 6) }\end{array}$ & $\begin{array}{l}\text { GIS was used to calculate the percentage of LCI projects within or adjacent to } \\
\text { identified ETA communities by overlaying LCI shapefiles on ETA areas. }\end{array}$ \\
\hline
\end{tabular}

In measuring these factors and their impacts proposed within the 2040 plan, the ARC ultimately observed per capita investments were proportional, relative to the rest of the non-ETA region; multimodal accessibility would be enhanced; and there would be an improvement in the 
jobs-housing balance (Comparative Analysis, n.d.). Additionally, the ARC views these methodologies as a means of providing a way to analyze system-level equity; provide projectlevel analysis when needed in the evaluation of burdens vs. benefits; and gain additional insight into the needs of ETA communities for decision making or to guide further community analysis.

\section{References}

Atlanta Regional Commission (ARC). Volume I: Plan 2040 Regional Transportation Plan (RTP). Retrieved from http://documents.atlantaregional.com/plan2040/docs/tp_PLAN2040RTP_072711.pdf.

\subsection{POLK TRANSPORTATION PLANNING ORGANIZATION (TPO)}

\section{Identifying Communities of Concern}

The Polk Transportation Planning Organization (TPO) conducted a neighborhood mobility audit focused on traditionally underserved neighborhoods. These neighborhoods contained notable concentrations of:

- Minorities

- Low-income populations

- Transportation-disadvantaged persons

The transportation disadvantaged were defined as those who were 65 years old or older, persons with disabilities, carless households, or those who were 15 years old or younger who could not legally operate a vehicle.

Census block groups were used to identify concentrations of minority and low-income populations that were well above Polk County averages. Areas were ranked based on concentration levels. Polk TPO staff and Technical Advisory Committee (TAC) members further defined these neighborhood boundaries using elements such as housing type, travel and social patterns.

\section{Determining Project Needs}

The Polk TPO actively promotes best practices to advance livable communities in support of the Livable Polk Initiative. To identify ways to enhance multimodal connections to essential services and jobs, the TPO performed a series of neighborhood-level mobility audits. These audits focused on evaluating neighborhood mobility issues in areas with higher concentrations of traditionally underserved populations.

\section{Methods for Evaluating Equity}

A combination of six indices were used to describe the overall mobility of each neighborhood studied regarding opportunities to walk, bike or take transit, as well as hindrances to mobility, such as gaps and barriers. The six indices used in the neighborhood-based analysis are listed in Table A-3. 
Table A-3. Evaluating Neighborhood Mobility in Polk County

\begin{tabular}{|l|l|}
\hline Audit Type & \multicolumn{1}{|c|}{ Purpose } \\
\hline $\begin{array}{l}\text { Walking } \\
\text { (p. 8) }\end{array}$ & $\begin{array}{l}\text { Used to measure walking potential, it assesses the potential for quarter-mile walking } \\
\text { trips to community services and places. }\end{array}$ \\
\hline $\begin{array}{l}\text { Biking } \\
\text { Access } \\
\text { p. 10) }\end{array}$ & $\begin{array}{l}\text { Used to measure biking potential, it assesses the potential for one-mile biking trips to } \\
\text { community services and places. }\end{array}$ \\
\hline $\begin{array}{l}\text { Transit } \\
\text { Connectivity } \\
\text { p. 12) }\end{array}$ & $\begin{array}{l}\text { Used to measure transit connectivity, it assesses the potential to have access to } \\
\text { community services and places by looking at the location, intensity and frequency of } \\
\text { transit service in the area. }\end{array}$ \\
\hline $\begin{array}{l}\text { Gaps } \\
\text { (p. 14) }\end{array}$ & $\begin{array}{l}\text { Used to determine whether areas within the neighborhood have a higher or lower } \\
\text { number of sidewalk gaps in comparison to the location of community services and } \\
\text { places. It assesses the presence of transportation network gaps, specifically sidewalk } \\
\text { network gaps, which may hinder the potential for walking or biking trips. }\end{array}$ \\
\hline $\begin{array}{l}\text { Barriers } \\
\text { (p. 15) }\end{array}$ & $\begin{array}{l}\text { Used to determine whether areas within the neighborhood have a higher or lower } \\
\text { number of barriers in comparison to the location of community services and places. It } \\
\text { assesses the presence of three features that may hinder the potential for walking or } \\
\text { biking trips. }\end{array}$ \\
\hline $\begin{array}{l}\text { Mobility } \\
\text { (p. 17) }\end{array}$ & $\begin{array}{l}\text { Used to summarize the overall mobility within each neighborhood and the level of } \\
\text { mobility assigned based on the cumulative score. }\end{array}$ \\
\hline
\end{tabular}

\section{Methods of Analysis}

For consistency sake, a quarter-mile grid, which was representative of the typical maximum walking distance, was laid over the study areas consisting of neighborhoods with higher than average concentrations of traditionally underserved populations. Under each of the walking and biking access indices, calculations were made based on three walking or biking trip factors (connectivity, dwelling density and diversity in use) respectively; ranked accordingly (from 0-3, with 3 being the highest); and then tallied to produce a cumulative score for each quarter-mile square under each index.

In order to calculate the Transit Connectivity Index (TCI), data was also used from Polk County Transit Services, Citrus Connection, Winter Haven Area Transit (WHAT) fixed-bus routes, and the number of weekly transit trips (by route and frequency) from Polk County, WHAT and Lakeland Area Mass Transit District. The following formula was used: TCI = (Route buffer intersecting quarter-mile square) / (Total Quarter-Mile Square Area). Quarter-mile squares were divided into ranges based on their TCI scores and ranked accordingly (from 0-3, with 3 being the highest and indicates better transit coverage in the area studied).

Since the county did not have an existing sidewalk network GIS file to move forward with its gaps index, sidewalks were digitized using roadway centerline data in GIS. Sidewalk gap calculations were done in order to determine the percent of roadway network that had no 
sidewalk (per quarter-mile square) and placed into four ranges (from $0-3$, with 0 being a minimal level of gaps being present while three representing no infrastructure were present). Under the barriers index individual calculations were made based on the three features that may have hindered the potential for walking or biking (roadway, railroad and waterway), and then were ranked accordingly (from $0-3$, with 3 being the highest).

The mobility index was used to summarize the overall mobility within each neighborhood by looking at all of the accessibility/potential for accessibility and deducting hindrances. Scoring weight for transit was higher because of the importance of transit in serving traditionally underserved communities, and because gaps and barriers have the potential to reduce access or overall mobility by up to $50 \%$. A discount factor up to $25 \%$ of the potential access was applied to both indices. The formula Polk TPO used to determine the level of mobility was based on the cumulative score of the mobility index, which consisted of: Mobility Index $=$ Potential Access - Gaps Discount - Barriers Discount.

\section{Application of Findings}

Using the results of its mobility audits, the Polk TPO created easy, visual comparisons between levels of mobility across different neighborhoods using neighborhood mobility dashboards. The dashboards are graphical representations of the five individual indices and include a separate one containing the mobility index results. These were created in the attempt to help prioritize neighborhoods for transportation investments.

One of the neighborhoods that the Polk TPO uses as an example within its report was a mobility audit for its East Bartow neighborhood. It allowed them to see that they specifically needed to focus on closing pedestrian/bicycle infrastructure gaps as well as strengthen access across major barriers. Additionally, it provided an opportunity to consider other opportunities to improve access outside of the neighborhood core that would also improve walking, biking and transit access.

Going forward, Polk TPO would like to use the results of these and future audits, and overlay them over improvement recommendations already noted within its planning documents in order to identify if the neighborhoods with the greatest needs are in line to get mobility enhancements. And, if there are few or no overlaps, to use those observations to provide push for additional enhancements as amendments or in future planning documents for those areas.

\section{References}

Polk Transportation Planning Organization (PTPO). (2015b). Neighborhood Mobility Audits. Retrieved from http://polktpo.com/media/33968/L4-Neighborhood-Mobility-Audits.pdf.

\subsection{SAN DIEGO ASSOCIATION OF GOVERNMENTS (SANDAG)}

\section{Identifying Communities of Concern}

The San Diego Association of Governments (SANDAG) conducted a series of health assessments focused on physical activity and active transportation, injury prevention, nutrition and air quality, and assessed their impact, particularly on communities of concern. These communities of concern were defined as:

- Low-income populations

- Minorities 
- Low-mobility populations

- Areas where there is low community engagement

Areas noted as having low-mobility had populations where $25 \%$ had a disability, 20\% were over 65 years old, and more than $25 \%$ did not own a car.

Areas where there was a low community engagement had more than $20 \%$ of their population made up of persons with disabilities, 20\% of their households do not speak English, and more than $20 \%$ of their population did not have a high school diploma.

The 2010 census tract data for the communities of concern was provided by SANDAG and broken down to block groups. It was found that "nearly two-thirds of all Census block groups in the region have one or more Communities of Concern" and "there is a large degree of geographic overlap” between the different populations in these areas (p.6).

\section{Determining Project Needs}

SANDAG conducted health assessments to provide guidance to local governments in its planning process.

\section{Methods of Analysis and Findings}

Four health assessment categories were used in the assessment of impacts on communities of concern, as shown in Table A-4. For each health assessment, one or more factors were considered to determine its impact on the health of a community. Listed below are the method of analysis for selected factors.

Table A-4. Evaluating Health in Communities

\begin{tabular}{|l|l|}
\hline $\begin{array}{l}\text { Health Assessment } \\
\text { Category }\end{array}$ & Factors Considered \\
\hline $\begin{array}{l}\text { Physical Activity and } \\
\text { Active Transportation (p. }\end{array}$ & $\begin{array}{l}\text { Utilitarian Walkability } \\
\text { Sidewalks } \\
\text { Access to Transit Stations and Stops } \\
\text { Parks and Open Space Access } \\
\text { Non-motorized Trails Access } \\
\text { Transportation Infrastructure Support } \\
\text { Access to Social Support and Amenities } \\
\text { Complete Neighborhoods and Community Support } \\
\text { Youth Physical Activity Support } \\
\text { Physical Disorder and Crime } \\
\text { Road Design } \\
\text { Physical Activity Inhibitors }\end{array}$ \\
\hline Injury Prevention (p. 49) & $\begin{array}{l}\text { Traffic Crashes } \\
\text { Pedestrian Traffic Safety } \\
\text { Cyclist Safety } \\
\text { Traffic Safety for Youth }\end{array}$ \\
\hline Nutrition (p. 63) & $\begin{array}{l}\text { Healthy Foods Access } \\
\text { Fast Food Density }\end{array}$ \\
\hline Air Quality (p. 69) & Pollution and its Health Risks \\
\hline
\end{tabular}




\section{Utilitarian Walkability}

This analysis used the Walkability Index to determine the walkability of each block group has been vetted by over 20 peer-reviewed journals. The Walkability Index consists of: 1) retail floor area ratio (FAR) used to identify whether sites are oriented for pedestrians; 2) intersection density used to measure street-network connectivity and used to identify the number of intersections in a block group, as the greater the density the better network pedestrians have to walk and have more efficient walking travel times; 3) net residential density used to measure the compactness of residences; and 4) land use mix used to measure the proximity of different land use types to one another, where all standardized values are added and the intersection density is weighted twice that of the others.

A cumulative Walkability Index was used to combine the results of all four walkability components (all four received standardized values and the intersection density was weighted twice more than the others). The information was obtained from 2006 parcel data (i.e., land use categories, area of land dedicated to each land use, parcel boundaries, and the number of housing units in each parcel). As evidenced in Figure 13, they found that the urban core of San Diego had the "largest continuous high-walkability area" (p. 13), there were also several smaller walkable areas that were right outside the urban core boundary, and there were similar patterns in several other cities. 


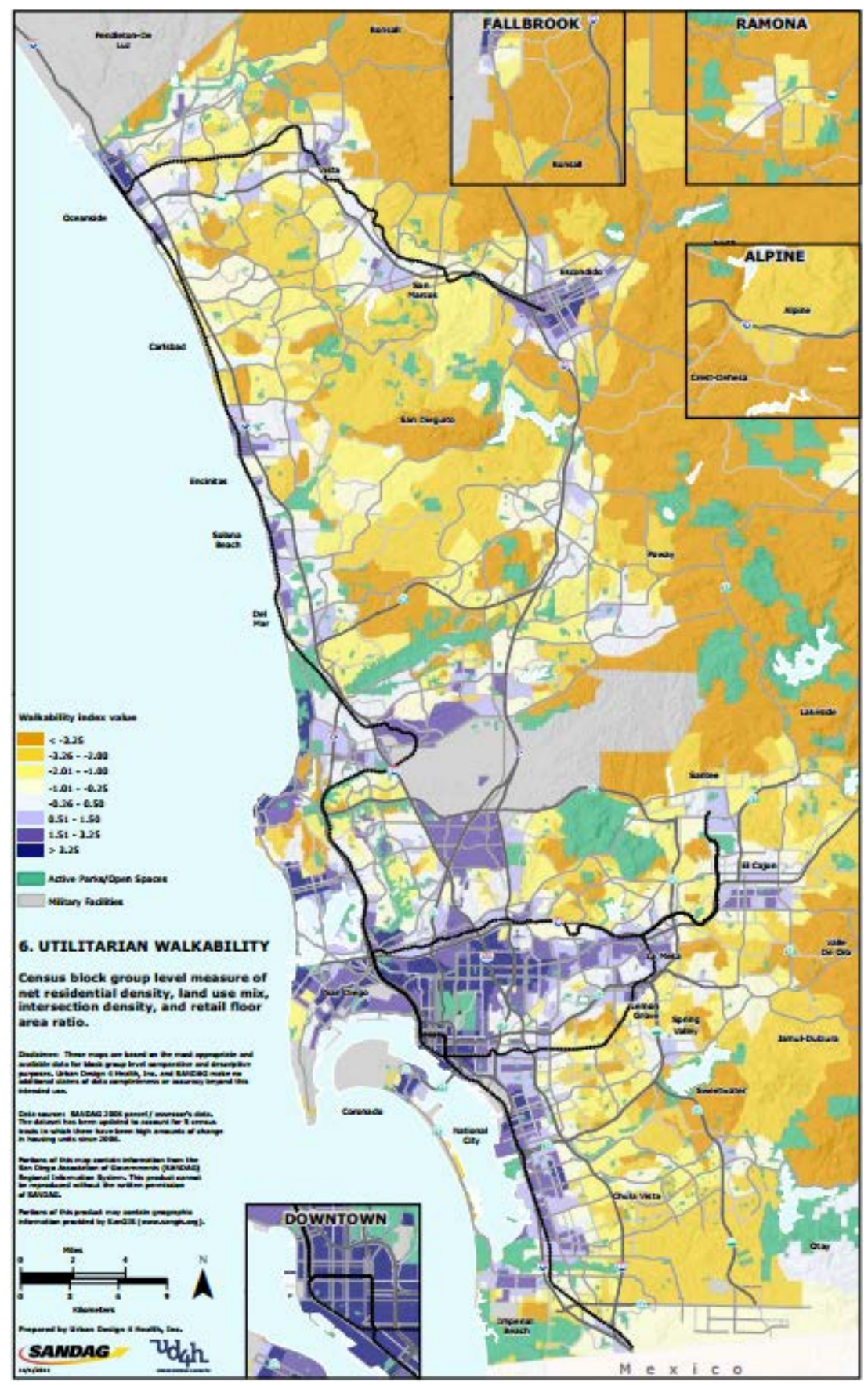

Figure 13. Results from a walkability analysis in San Diego.

Source: SANDAG, 2012

\section{Sidewalks}

This analysis focused on the completeness of sidewalk networks in each block group as it enables walking, draws more people to the area, has been associated with lower rates of overweight status, and contributes to safety and a decrease in traffic-induced injuries to pedestrians. "The ratio of total sidewalk miles to the number of total roadway miles in each 
Census block” (p.16) was measured. The 2011 regional sidewalk inventory for the urban area was used, so block groups outside of the boundaries were not taken into consideration and classified as "insufficient data." They found that the sidewalk coverage in much of the urban core was high and many of the block groups home to the communities of concern had sidewalk networks that were $73 \%$ or more complete.

\section{Access to Transit Stations and Stops}

This analysis focused on the proportion of households that were within walking distance of "high-quality" transit in each block group. Transit data was retrieved from 2010 SANDAG data and "pre-established SANDAG transit service criteria were used to identify high-quality transit locations" (p.18) because proximity to them is an important predictor to walking/increased physical activity. They found the distribution of transit accessibility within the block groups was bimodal, meaning that access was either very good or very limited, and largely due to transit services being concentrated along major rail corridors. Nearly $40 \%$ of households were within walking distance of a high-quality transit service, including a large portion of the block groups with communities of concern. However, there were substantial portions that had little to no access, and for populations where mobility may already be an issue, the lack of transit access can make mobility for these populations even worse.

Parks and Open Spaces Access: This analysis focused on the percentage of households within walking distance of park entrance points or open space (i.e., areas associated with higher levels of physical activity) in each census block group. Parks data was retrieved from the Neighborhood Quality of Life study and 2004-2005 SANDAG parks and open space data set. Findings were that many have access to open space and parks in the region, with almost $60 \%$ of households within walking access of one. However, in the urban areas, access is typically either very high or very low. Nearly half of the block groups with communities of concern had high levels of access to parks; however, a significant portion had very low levels of access.

Non-motorized Trails Access: This analysis focused on measuring access to nonmotorized trails because they provide recreational opportunities, serve as active transportation corridors, and can even attract those who would not have otherwise chosen to ride a bicycle. The percentage of housing units within approximately a 12-20 minute walk or 15-16 minute bike ride of non-motorized trails were retrieved from 2009 SANDAG data (used bicycle-network data). They found access to trails is generally low. For communities of concern, almost two-thirds of the block groups had no nearby access and only $10 \%$ had very good access. In general, access to non-motorized trails for block groups with communities of concern was similar to that of the rest of the region - either very high or very low.

\section{Transportation Infrastructure Support}

This analysis focused on identifying “where the region’s network of transportation infrastructure supports physical activity, or where an infrastructure deficit could inhibit physical activity” (p.24). Several factors were considered, including non-motorized trails access, access to transit stations and stops, and sidewalk completeness, of which each was given a standardized value and a composite score was created by averaging them. As evidenced in Figure 14, they found that the highest levels of transportation infrastructure support were in the core neighborhoods. However, the lack of non-motorized trail coverage lowered the support in urban areas. The largest block groups with communities of concern had very high levels of support. 


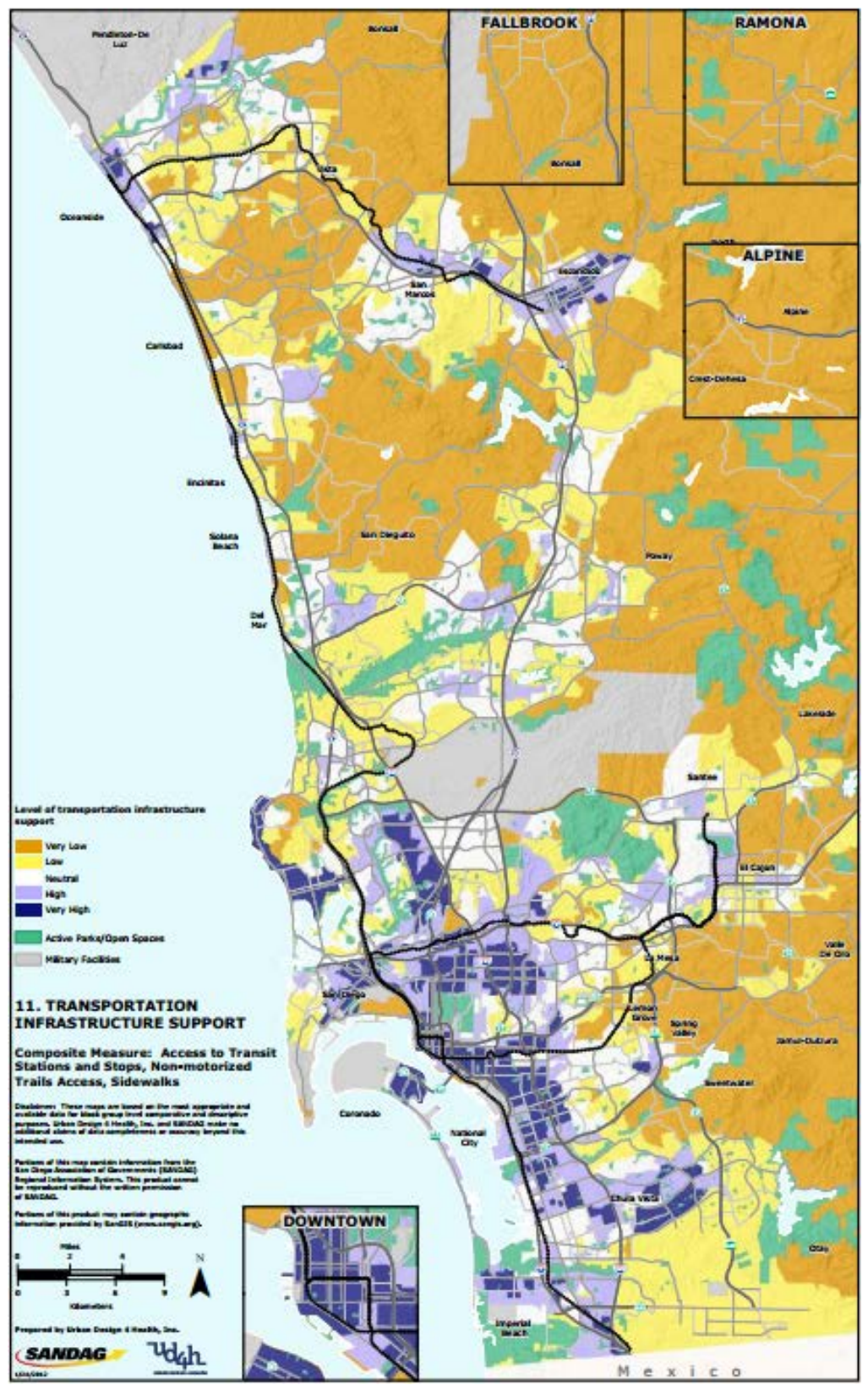

Figure 14. Available transportation infrastructure and support in San Diego.

Source: SANDAG, 2012

\section{Access to Social Support and Amenities}

This analysis focused on identifying public amenities and sources for social support within walking distance of households because they are contributors to health and well being overall. Four types of amenities were reviewed (i.e., library access, daycare facility access, healthcare facility access, and elementary school access) to identify the proportion of households that were within walking distance of each in each block group. The 2010 parcel-level land use and dwelling-unit data from SANDAG was used to determine the household counts as well as 
2007 SanGIS and 2010 Urban Design 4 Health data was used for the amenities. They found the block groups with the communities of concern generally mimicked that of the broader region, which was that there was good access to daycare facilities in the urban core; lower access to libraries, although more evenly distributed in the urban areas; and with clinics and hospitals being placed primarily in urbanized areas, few outside of the urban centers were within walking distance and so access was low. Lastly, in terms of elementary schools, there was a high level of access throughout the region but especially within urban and some suburban areas.

\section{Complete Neighborhoods and Community Support}

This analysis focused on identifying areas that had the best access, within walking distance of households, to different types of destinations because complete neighborhoods provide a variety of amenities and destinations that are walkable or bikeable and/or transit options to access them. The households in each block group that had 50\% or more that had access to four or more of these destinations were highlighted when eight base maps were combined. They found there is a good amount of overlap between areas with a substantial amount of community support and communities of concern.

\section{Youth Physical Activity Support}

This analysis focused on identifying urban design factors that are specifically associated with being predictors of walking and/or physical activity in youth rather than adults. Several factors were considered, including sidewalk completeness, elementary school access, parks and open space access, and non-motorized trails access, of which each was given a standardized value and a composite score was created by averaging them. They found the block groups with communities of concern were categorized as high and very high in terms of support for physical activity for youth.

\section{Physical Disorder and Crime}

This analysis focused on identifying the presence of physical disorder (i.e., vandalism, a large amount of vacant lots, litter on the streets); crime; and the perception of the existence of both as they both can discourage walking, bicycling, and other physical outdoor activities. These discouragements and reductions in physical activities have been associated with obesity and a reduction in physical activity overall. Crime (i.e., in regards to vandalism/malicious mischief, robbery, rape, homicide, simple assault, and aggravated assault) and physical disorder (i.e., vandalism and malicious mischief) data was retrieved from the Automated Regional Justice Information System (ARJIS) for the years 2007-2010 and vacant parcel data was retrieved from 2010 SANDAG data. Using block group level data, they found that the groups with communities of concern mirrored findings found within the entire region overall. They found a distinct pattern of physical disorder and crime, where there is a disproportionate amount of both found in urban areas. However, in regards to the presence of vacant parcels, it was distributed more evenly than when looking at physical disorder and crime.

\section{Road Design}

This analysis focused on road design and heavy traffic measures, as the promotion of vehicle use has been at the expense of other travel modes and can compromise pedestrian and cyclist safety. Specific road design measures (i.e., road width, road type) and traffic volumes are associated with higher collision frequencies, pedestrian crash rates, higher motor vehicle speeds 
and increases in the number of crashes. The perception of roads being unsafe or unpleasant has also translated into decreases in active transportation. SANDAG looked at two road design measures (i.e., arterial density and traffic volume density), and the data was retrieved from the 2008 SANDAG traffic volume dataset and the 2006 SANDAG road data. Traffic volume density was calculated and then the estimated "vehicle miles traveled (VMT) for each block group was divided by the block group's area, resulting in the final traffic volume density" (p.42). The arterial density was calculated by dividing the total length of arterials (in each block group) by the block group area. And though they found that a large portion of the block groups with communities of concern overlap with the remainder of the region, they recognized that they typically increased along with arterial and traffic volume density. Generally speaking, this observation was seen in all block groups along the region's major roadway network.

\section{Physical Activity Inhibitors}

This analysis focused on determining actual or the perception of deterrents to walking and outdoor physical activity, which could include crime, traffic danger, and physical and perceived deterrents. Several factors were considered, including physical disorder, traffic volume density, violent crime, arterial density, and vacant parcels, of which each were given a standardized value. A composite score was created by averaging them.

\section{Traffic Crashes}

This analysis focused on assessing the amount of traffic crashes, as they are a serious health threat to both pedestrians and cyclists physically as well as mentally since the perception of danger can deter walking, cycling, and/or any other physical activity, particularly by those who are elderly or young children. Four types of crashes were reviewed including: pedestrianinvolved motor vehicle crashes, the cyclist crash rate, cyclist-involved motor vehicle crashes, and the pedestrian crash rate. This data, which focused on data that involved pedestrians and cyclists, was retrieved from the 1998-2007 Statewide Traffic Reporting System (SWTRS). It found that the block groups with communities of concern greatly mimicked what was found across the region, which is that there were high crash rates observed, especially downtown, as well as the centers of other cities and highway corridors. In addition, pedestrian crash rates were only slightly lower than cyclist crash rates. However, they did find with the communities of concern that there was an overlap between these block groups and the areas where crash rates were the highest.

\section{Pedestrian Traffic Safety}

This analysis focused on identifying block groups that had high risk potential for pedestrian injury. A composite score was created based on the average of several factors (i.e., sidewalk completeness, traffic volume density, arterial density, and pedestrian crash rate) that each had a standardized value. As evidenced in Figure 15, they found a large portion of block groups with communities of concern were considered to have very low pedestrian traffic safety, and very few had high or very high rankings. SANDAG noted this is indicative that these areas have vulnerable communities, especially in terms of traffic and safety barriers to walking, and addressing them should be beneficial. 


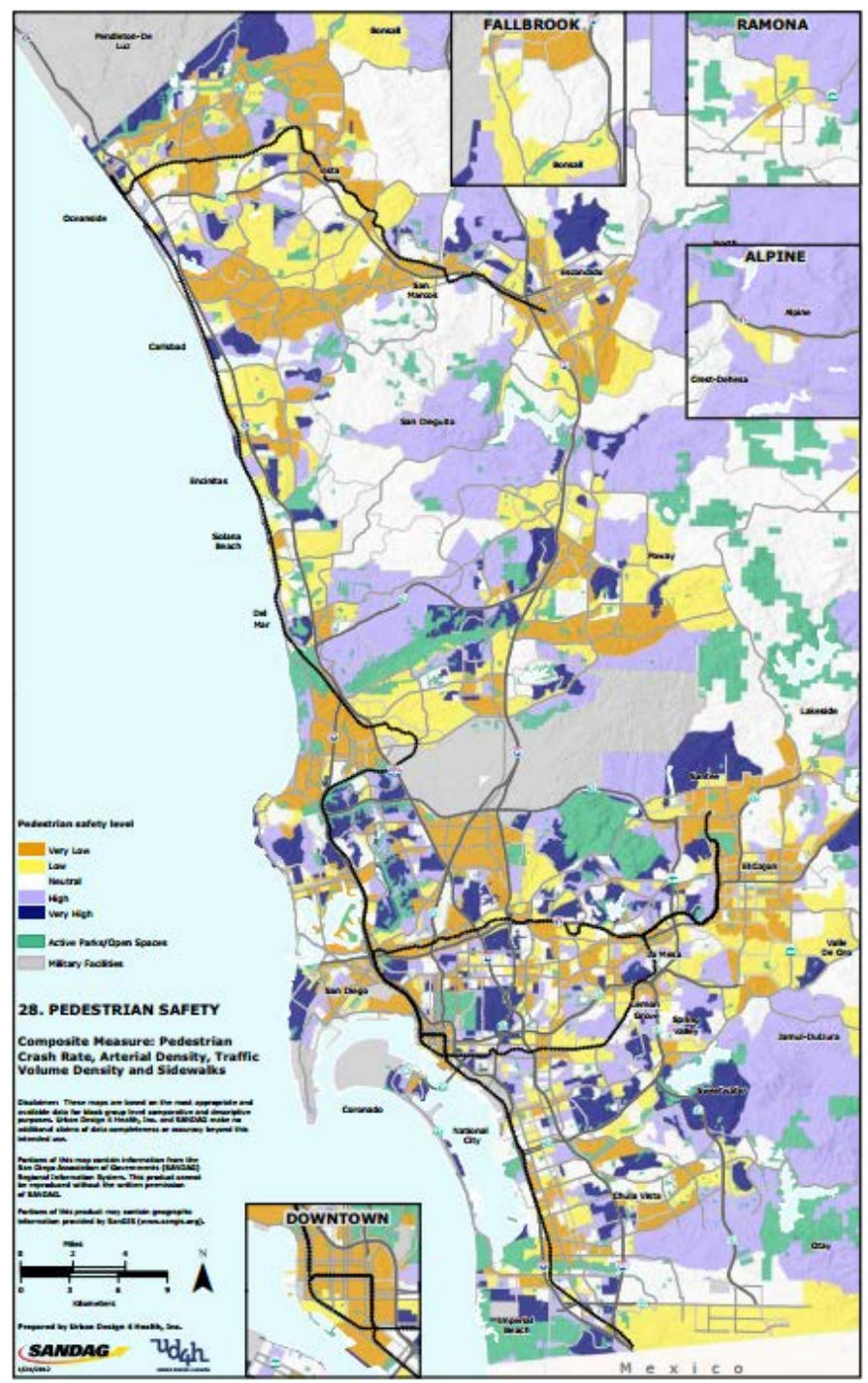

Figure 15. Pedestrian safety in San Diego.

Source: SANDAG, 2012

\section{Cyclist Safety}

This analysis focused on the potential high risk for cyclist injury. Several factors were considered, including non-motorized trails access, traffic volume density, arterial density, and cyclist crash rates, of which each was given a standardized value and a composite score was created by averaging them. They found the very low cyclist safety category had the most block groups with communities of concern, and suggested that mitigation and improvements in these areas could provide positive impacts and additional benefits to low-mobility populations and those with low income as well.

\section{Traffic Safety for Youth}

This analysis focused on the potential high risk for youths to injure themselves in traffic crashes. Using only block groups that had more than $50 \%$ of their households that had access to a 
park, elementary school or daycare center, the groups were selected based on the likelihood that young pedestrians or cyclists would be attracted to those areas. They were then given a composite score based on a combination of factors (i.e. sidewalk completeness, traffic volume density, arterial density, pedestrian crash rate, and cyclist crash rate) that were each given a standardized value for each block group and the composite score was the average of those scores. They found almost $85 \%$ of the block groups with communities of concern fell under low and/or very low traffic safety for youth categories.

\section{Healthy Foods Access}

This analysis focused on the accessibility to healthy foods because it can help contribute to a healthy diet and its associated positive benefits. Using grocery store location data from the Neighborhood Quality of Life Study (NQLS), "the percentage of households in each block group within walking distance of a grocery store or farmers' market” (p.64) was measured based on the distance decay principle, where people are most likely to make trips to nearby destinations. They found the block groups with communities of concern generally mimicked the results found within the region, where healthy food access was particularly high in urban cores and central cities and around major roadway corridors.

\section{Fast-Food Density}

This analysis focused on the concentration of fast-food restaurants as they are associated with higher fat intake. Using fast-food data from the Neighborhood Quality of Life Study (NQLS), the density of fast-food restaurants was measured per census block group. They found no immediately apparent relationships between the areas with communities of concern and fastfood density, as it greatly mimicked what occurred throughout the rest of the region. Generally speaking, throughout the region as a whole there was a higher density of fast food along major highway and arterial corridors and/or near interchanges. Interestingly, however, more than 50\% of the block groups had a fast-food density of zero.

\section{Air Quality}

This analysis focused on several pollutants where proximity and adjacent location were of the greatest concern to community health. Areas were identified as being "at risk to exposure to air pollution based on the percentage of homes in each block group that are within a zone of impact to three types of known transportation-related pollution sources: freeways and hightraffic roads, rail yards, and ports” (p. 69), where the zones of impact were based on the guidelines from the California Air Resources Board (CARB). They found the block groups with communities of concern generally mirrored what was found across the region, where concentrations of air pollution followed major highway corridors. The majority of block groups did not have a significant number of units that were within these impact zones; however, 108 had $50 \%$ or more.

\section{Application of Findings}

According to Coleen Clementson (2016), the principal regional planner for the San Diego Association of Governments, SANDAG uses these findings as guidance measures in its planning efforts (i.e., in its general plan updates, as well as in its community plans and/or other specific plans) throughout its 19 local jurisdictions. 


\section{References}

San Diego Association of Governments (SANDAG). (2012). Healthy Communities Atlas: San Diego Region, California. Retrieved from http://www.sandag.org/uploads/projectid/projectid_482_17468.pdf.

Clemenston, Coleen. “RE: Inquiring about your Healthy Communities Atlas Findings.” Message to Monica Martin. 9 March 2016. E-mail. 


\subsection{REFERENCES}

Adie Tomer, Jeffrey Gutman, and Adrianna Pita. August 31, 2016. Podcast: Inclusive cities: Transportation and accessibility. Brookings, Accessed:

https://www.brookings.edu/podcast-episode/inclusive-cities-transportation-andaccessibility/

Amekudzi, A., Smith, M., Brodie, S., Fischer, J., Ross, C. (2012). Impact of Environmental Justice on Transportation. Transportation Research Record: Journal of the Transportation Research Board, No. 2320.

Atlanta Regional Commission (ARC). (2014). Plan 2040. Appendix C-2: Performance Measures Portfolio. Retrieved from http://www.atlantaregional.com/plan2040/documents--tools Atlanta Regional Commission (ARC). (2011a) Plan 2040. Appendix C-3: Equitable Target Areas (ETA) Technical Analysis Methodology.

Retrieved from http://www.atlantaregional.com/plan2040/documents--tools Atlanta Regional Commission (ARC). (2011b) Volume I: Plan 2040 Regional Transportation Plan (RTP). Retrieved from http://documents.atlantaregional.com/plan2040/docs/tp_PLAN2040RTP_072711.pdf

Atlanta Regional Commission Transportation Planning Department (ARC). (n.d.) Comparative Analysis of PLAN 2040 Investments in Equitable Target Areas (ETA). Retrieved from http://www.atlantaregional.com/File\%20Library/Transportation/Plan\%202040/tp_PLAN _2040_ETA_Web.pdf

Association of Bay Area Governments, the Metropolitan Transportation Commission. (2013, July). Bay Area Plan: A Strategy for a Sustainable Region. Equity Analysis Report Including Title VI, Environmental Justice and Equity Analysis for Plan Bay Area. Retrieved from http://mtc.ca.gov/sites/default/files/A04_FINAL_PBA_Equity_Analysis_Report.pdf.

Baltimore Metropolitan Council. (2016). Maximize 2040. Retrieved from http://www.baltometro.org/our-work/transportation-plans/long-rangeplanning/maximize2040-draft-plan\#Maximize2040

Beebe, Craig. (2016). The Portland Metropolitan Area Grew by 111 People a Day from July 2014 to 2015, the Census Bureau Estimates. Oregon Metro News. Retrieved from: http://www.oregonmetro.gov/news/portland-region-nears-24-million-residents-growing41000-last-year

Boisjoly, G; El-Geneidy, A. (2017) How to Get There? A Critical Assessment of Accessibility Objectives and Indicators in Metropolitan Transportation Plans. Transport Policy. Vol 55 (38-50).

Center for Neighborhood Technology (CNT). (2010). $H+T$ Index. Retrieved from http://htaindex.cnt.org/

Center for Neighborhood Technology (CNT). (2006). Housing and Transportation Cost Tradeoffs and Burdens of Working Households in 28 Metros. Retrieved from: http://www2.nhc.org/media/documents/chp-pub-hl06-cnt-report.pdf 
Chakraborty, J. (2006). Evaluating the Environmental Justice Impacts of Transportation Improvement Projects in the U.S. Transportation Research Part D, 315-323

Chicago Metropolitan Agency for Planning (CMAP). (2010). Go To 2040: Comprehensive Regional Plan. Retrieved from http://www.cmap.illinois.gov/documents/10180/17842/long_plan_FINAL_100610_web. pdf/1e1ff482-7013-4f5f-90d5-90d395087a53

Chicago Metropolitan Agency for Planning (CMAP). (2008). Updated 2030 Regional Transportation Plan for Northeastern Illinois. Retrieved from http://www.cmap.illinois.gov/documents/10180/398086/UpdatedCompiledPlan_2008031 3_v1.pdf/a9b00e55-51cd-41b3-87ad-de26e4d11db4

Cho, Grace. 2018 RTP Performance Targets and System Measures - Overview and Work Group Task. Memorandum. June 1, 2016

Christensen, Nick. (2016). Portland Regions Grows to 2.35 Million Residents, Census Estimates, with Newcomers Leading the Way. Oregon Metro News. Retrieved from: http://www.oregonmetro.gov/news/portland-region-grows-235-million-residents-censusestimates-newcomers-leading-way

Currie, G. (2010). Quantifying spatial gaps in public transport supply based on social needs. Journal of Transport Geography, Vol. 18, No. 1, pp. 31-41.

Delaware Valley Regional Planning Commission (DVRPC). (2013a). Connections 2040: Plan for Greater Philadelphia. Retrieved from http://www.dvrpc.org/reports/13042.pdf

Delaware Valley Regional Planning Commission (DVRPC). (2009). Connections: The Long Range Plan for a Sustainable Future.

Delaware Valley Regional Planning Commission (DVRPC). (2013b). Environmental Justice at DVRPC, Fiscal Year 2012. Retrieved from http://www.dvrpc.org/reports/TM13023.pdf

Delaware Valley Regional Planning Commission (DVRPC). (2013c) Technical Analysis. Connections 2040: A Long Range Plan for the Greater Philadelphia Region. Retrieved from http://www.dvrpc.org/reports/13043.pdf

Delaware Valley Regional Planning Commission (DVRPC). (2012). Transportation Improvement Program (TIP) for New Jersey. Retrieved from http://www.dvrpc.org/tip/NJfinal/2012/TIP-Doc-NJ2012.pdf

Delaware Valley Regional Planning Commission (DVRPC). Transportation Improvement Program (TIP) (FY2013-2016). (2013d).

Federal Transit Administration (FTA). (2014). Evaluating Transportation Equity: An Intermetropolitan Comparison of Regional Accessibility and Urban Form. Retrieved from: https://www.transit.dot.gov/sites/fta.dot.gov/files/FTA_Report_No._0066.pdf

Florida Department of Transportation, Office of Policy Planning (FDOT). (2015). MPO Program Management Handbook, Chapter 9. Retrieved from http://www.dot.state.fl.us/planning/policy/metrosupport/mpohandbook/ch9.pdf

Hampton Roads Transportation Planning Organization (HRTPO). (2014). Public Involvement: Environmental Justice Methodology Tool. Retrieved from http://hrtpo.org/page/ejmethodology-tool/ 
Hampton Roads Transportation Planning Organization (HRTPO). (2015). Hampton Roads 2040 Long-Range Transportation Plan: Candidate Project Evaluation, Title VI/Environmental Justice Methodology (Draft). Retrieved from http://hrtpo.org/uploads/docs/050615TTAC-Enclosure\%20122040\%20LRTP\%20Candidate\%20Project\%20Evaluation\%20Title\%20VIEnvironmental\%20Justice\%20Methodology\%20Draft\%20Report2.pdf

Hillsborough Area Regional Transit Authority (HART). (2015). Transit Development Plan Update FY 2016-2025. Retrieved from http://www.gohart.org/Style\%20Library/goHART/pdfs/board/TDP_final_draft_092515.p df

Hillsborough County, Florida. (2016). About the County. Retrieved from http://www.hillsboroughcounty.org/index.aspx?nid=423

Hillsborough County Metropolitan Planning Organization (2004). Regional Jobs Access Plan Technical Update (2004). Retrieved from http://www.planhillsborough.org/wpcontent/uploads/2015/03/Regional-Jobs-Access-Plan-technical-update-2004.pdf

Hillsborough County Metropolitan Planning Organization (HMPO). (2015a). Hillsborough County Transportation Disadvantaged Service Plan - Final 2015 Update. Retrieved from http://www.planhillsborough.org/wp-content/uploads/2015/07/TDSP-06-26-2015ADA-Final-Deliverable.pdf

Hillsborough County Metropolitan Planning Organization (HMPO). (2014a). Imagine Hillsborough 2040: Long Range Transportation Plan for Tampa, Temple Terrace, Plant City, and Hillsborough County.

Hillsborough County Metropolitan Planning Organization (HMPO). (2009). 2035 Long Range Transportation Plan. Retrieved from http://www.planhillsborough.org/mpo-2035-lrtp/

Hillsborough County Metropolitan Planning Organization. (2000). Regional Jobs Access Plan (2000). Retrieved from http://www.planhillsborough.org/wpcontent/uploads/2015/03/Regional-Jobs-Access-Plan-final-report-2000.pdf

Hillsborough Area Regional Transit Authority (HART). (2015, September). Transit Development Plan Update: Fiscal Year 2016 - Fiscal Year 2025.Retrieved from http://www.gohart.org/Style\%20Library/goHART/pdfs/board/TDP_final_draft_092515.p $\mathrm{df}$

Hillsborough County Metropolitan Planning Organization (HMPO). (2015c). Hillsborough County Areawide Vision Map. Retrieved from http://www.planhillsborough.org/wpcontent/uploads/2015/09/Hillsborough_County_Areawide_Vision_map_11_x_17_REDU CED.pdf

Hillsborough County Metropolitan Planning Organization (HMPO). (2015b). Transportation Disadvantaged Program - Community Transportation Coordinator Evaluation for July 1, 2013 - June 30, 2014. Retrieved from http://www.planhillsborough.org/wpcontent/uploads/2015/03/Final-2014-APR_Hillsborough-CTC_Eval_ADA.pdf

Hillsborough County Metropolitan Planning Organization (HMPO). (2014b). Tri-County Area Regional Mobility Needs. Retrieved from http://www.planhillsborough.org/wpcontent/uploads/2014/06/Regional-Mobility-Needs-Chapter_2.27.14.pdf 
Houston-Galveston Area Council (HGAC). (2011). Bridging Our Communities 2035: The 2035 Houston-Galveston Regional Transportation Plan Update. Retrieved from http://www.hgac.com/taq/plan/documents/2035_update/2035\%20RTP\%20Update\%20FINAL\%20201 1-01-21.pdf

Karner, A.(2016) Planning for Transportation Equity in Small Regions: Towards Meaningful Performance Assessment. Transport Policy, Volume 52.

Karner, A., Niemeier, D. (2013). Civil Rights Guidance and Equity Analysis Methods for Regional Transportation Plans: A Critical Review of Literature and Practice. Journal of Transport Geography, 33.

Kramer, J., Williams, K., Seggerman, K., Bond, A. (2011). The Relationship of Title VI Requirements to Planning Process in Florida. Center for Urban Transportation Research.

Kjellstrom, T., Friel, S., Dixon, J. et al. (2007). Urban Environmental Health Hazards and Health Equity. Journal of Urban Health (2007) 84(Suppl 1): 86. doi:10.1007/s11524007-9171-9

Litman, T. (2016). Evaluating accessibility for transportation planning: Measuring people's ability to reach desired goods and activities. Victoria Transport Policy Institute. Retrieved from http://www.vtpi.org/access.pdf.

Litman, T. (2017) Evaluating Transportation Equity: Guidance for Incorporating Distributional Impacts in Transportation Planning. Victoria Transport Policy Institute. Retrieved from http://www.vtpi.org/equity.pdf.

Lowe, K. (2014). Bypassing Equity? Transit Investments and Regional Transportation Planning. Journal of Planning Education and Research, Volume 34(I) 30-44.

Mamun, S. A., N. E. Lownes, J. P. Osleeb, and K. Bertolaccini. (2013). A method to define public transit opportunity space. Journal of Transport Geography, Vol. 28, pp. 144-154.

Manaugh, K., Badami, M., El-Geneidy, A. (2014). Integrating Social Equity into Urban Transportation Planning: A Critical Evaluation of Equity Objectives and Measures in Transportation Plans in North America. Transport Policy. Retrieved from http://www.sciencedirect.com/science/article/pii/S0967070X14002145

Marcantonio, R. and A. Karner (2016). "Social Equity in Transportation Planning: A Community-Based Framework." Progressive Planning 206: 38-41

Martens, K., Golub, A. (2014a). A Fair Distribution of Transportation Benefits: Interpreting Civil Rights Regulations for Transportation Investment Programs. Transportation Research Part A.

Martens, K., Golub, A., Robinson, G. (2012). A Justice-Theoretic Approach to the Distribution of Transportation Benefits: Implications for Transportation Planning Practice in the United States. Transportation Research Part A.

Martens, K. Justice in Transport as Justice in Accessibility: Applying Walzer's "Spheres of Justice” to the Transport Sector. (2012). Transportation, Vol. 39, No. 6, Nov. 2012, pp. 1035-1053.

Martens, K., Golub, A. (2014b). Using Principles of Justice to Assess the Modal Equity of Regional Transportation Plans. Journal of Transport Geography, 41. 
Maricopa Association of Governments (MAG). (2014). 2035 Regional Transportation Plan (RTP). Retrieved from https://www.azmag.gov/Documents/RTP_2014-01-30_Final2035-Regional-Transportation-Plan-(RTP).pdf

McCahill, C, Ebeling, M. (2015). Tools for Measuring Accessibility in an Equity Framework. Congress for New Urbanism $23^{\text {rd }}$ Annual Meeting. Retrieved from https://www.cnu.org/sites/default/files/ssti_transpo_equity.pdf

Metro Regional Government. (July 2014). 2014 Regional Transportation Plan.

Metro Regional Government (July 2014). 2015-2018 Metropolitan Transportation Improvement Program Environmental Justice and Title VI Adoption Draft Report.

Metropolitan Transportation Commission (MTC). (2005). 2030 Plan Equity Analysis Report.

Miami-Dade Metropolitan Planning Organization (MDMPO). (2014a). Mobility Options 2040. Miami-Dade Transportation Plan: Eyes on the Future. Retrieved from http://www.miamidade2040lrtp.com/wp-content/uploads/2040_LRTP_Plan.pdf

Miami-Dade Metropolitan Planning Organization (MDMPO). (2014b). Title VI Report 2011 2014. Retrieved from http://miamidadempo.org/library/reports/title-vi-report-20112014.pdf

National Center for Transit Research (NCTR). (2016). Linking Greenways and Transportation in Florida. Retrieved from http://www.dot.state.fl.us/researchcenter/Completed_Proj/Summary_PTO/FDOT-BDV26-977-03-rpt.pdf

New York Metropolitan Transportation Council (NYMTC). (2009, June). Environmental Justice Assessment. Retrieved from http://www.nymtc.org/rtp/documents/related/nymtc_rtp_ej.pdf

National Institute for Transportation and Communities (NITC). (2016). Memo to Transportation Equity Work Group and Interested Parties: Review of Federal and State Requirements for Incorporating Social Equity in Regional Transportation Planning.

North Central Texas Council of Governments (NCTCOG). (2013). Mobility 2035 - 2013 Update. Retrieved from http://www.nctcog.org/trans/mtp/2035/index.asp

North Jersey Transportation Planning Authority (NJTPA). (2009). Appendix C, NJTPA Strategy Evaluation Study Report: Identifying Accessibility, Mobility, and Congestion Needs and Strategies for Northern New Jersey. Retrieved from http://www.njtpa.org/getattachment/Planning/Plan-Update-to-2040/Plan2035/Appendix_C_StrategyEval.pdf.aspx

North Jersey Transportation Planning Authority (NJTPA). (2005). Environmental Justice Regional Analysis Proportional Distribution of Benefits of Transportation Projects in the NJTPA Region.

North Jersey Transportation Planning Authority (NJTPA). (2011). Performance Results: Assessing the Implemented Transportation Projects. Guidebook for Project Performance Management. Retrieved from http://www.njtpa.org/planning/regional-studies/recentlycompleted-studies/performance-results-assessing-the-impacts-ofimple/performanceresults/njtpa_performanceresults_finalguidebook_complete_0.aspx 
North Jersey Transportation Planning Authority (NJTPA). (2013). Plan 2040 (Draft). Retrieved from http://www.njtpa.org/planning/plan-update-to2040/plan2040_draft_for_comment.aspx

Omaha-Council Bluffs Metropolitan Planning Agency (OCBMPA). (2015). Transportation Improvement Program: FY 2016-2021. Retrieved from http://mapacog.org/wpcontent/uploads/2015/10/MAPA_FY2016_TIP_Final.pdf

Pfeffer, N., Wen, F., Hasan, I. (1998). Environmental Justice in the Transportation Planning Process: Southern California Perspective. Transportation Research Record 1792, paper number 02-4099.

Polk Transportation Planning Organization (PTPO). (2015a). Momentum 2040: Long Range Transportation Adoption Package. Retrieved from http://polktpo.com/media/36181/PolkMomentum-2040_11-23-2015_Smaller.pdf

Polk Transportation Planning Organization (PTPO). (2015b). Neighborhood Mobility Audits. Retrieved from http://polktpo.com/media/33968/L4-Neighborhood-Mobility-Audits.pdf

Polk Transportation Planning Organization (PTPO). (2015c). Neighborhood Mobility Audits (Pamphlet).

Polk Transportation Planning Organization (PTPO), Polk Transit (PT). (2015d). Public Participation Plan. Retrieved from http://polktpo.com/media/33421/11-adopted-publicparticipation-plan.pdf

Portland Metro Regional Government (PMRG). (2014). Making a Great Place: Regional Transportation Plan. Retrieved from http://www.oregonmetro.gov/sites/default/files/RTP-2014-final.PDF

Puget Sound Regional Council (PSRC). (2014). Transportation 2040 Update Report: Toward a Sustainable Transportation System. Retrieved from http://www.psrc.org/assets/10550/T2040Update2014.pdf?processed=true

Rowangould, D.; Karner, A.; London, J. (2016).Identifying Environmental Justice Communities for Transportation Analysis. Transportation Research Part A: Policy and Practice. Vol. 88 (151-162).

San Diego Association of Governments (SANDAG). (2012). Healthy Communities Atlas: San Diego Region, California. Retrieved from http://www.sandag.org/uploads/projectid/projectid_482_17468.pdf

Smart Growth America. (May 2014) Dangerous by Design 2014, National Complete Streets Coalition.

Southern California Association of Governments (SCAG). (2016). Regional Transportation Plan 2016-2040, Environmental Justice Appendix. Retrieved from http://scagrtpscs.net/Documents/2016/final/f2016RTPSCS_EnvironmentalJustice.pdf

Southern California Association of Governments (SCAG). (2012). Regional Transportation Plan 2012-2035, Environmental Justice Appendix. Retrieved from http://rtpscs.scag.ca.gov/Documents/2012/final/SR/2012fRTP_EnvironmentalJustice.pdf 
Southern California Association of Governments (SCAG). (2008). Regional Transportation Plan (RTP): Making the Connections. Environmental Justice Report. Retrieved from http://rtpscs.scag.ca.gov/Documents/2008/fEnvironmentalJustice.pdf

Together North Jersey (TNJ). (2013). Regional Fair Housing \& Equity Assessment. Retrieved from http://togethernorthjersey.com/wpcontent/uploads/2013/07/FHEA_Maps_Intro_fixed.pdf

United States Department of Transportation (USDOT). (2012a) Department of Transportation Order 5610.1(a): Final DOT Environmental Justice Order. Retrieved from http://www.fhwa.dot.gov/environment/environmental_justice/ej_at_dot/orders/order_561 02a/index.cfm

United States Department of Transportation (USDOT). (2012b). Department of Transportation Environmental Justice Order 5610.2(a). Retrieved from https://www.fhwa.dot.gov/environment/environmental_justice/ej_at_dot/orders/order_56 102a/index.cfm

United States Department of Transportation (USDOT). (2016a). Letter to Colleagues Regarding the National Transit Map. Anthony Foxx.

United States Department of Transportation (USDOT). (2016b). Ladders of Opportunity. Retrieved from https://www.transportation.gov/opportunity

United States Federal Highway Administration (FHWA). (2015a). Livability in Transportation Guidebook. http://www.fhwa.dot.gov/livability/case_studies/guidebook/chap01.cfm\#ft14

United States Federal Highway Administration (FHWA). (2015b). Planning Emphasis Areas for Federal Fiscal Year 2015. Retrieved from https://www.fhwa.dot.gov/planning/processes/metropolitan/mpo/fy_2015/index.cfm

United States Federal Highway Administration (FHWA). (2016). Planning Emphasis Areas for Federal Fiscal Year 2016. Retrieved from https://www.fhwa.dot.gov/planning/processes/metropolitan/mpo/fy_2016/index.cfm

United States Federal Highway Administration (FHWA). (2012). FHWA Environmental Justice Order 6640.23A. Retrieved from https://www.fhwa.dot.gov/legsregs/directives/orders/664023a.cfm

U.S. DOT FHA. (2015). Livability in Transportation Guidebook. Retrieved from http://www.fhwa.dot.gov/livability/case_studies/guidebook/chap01.cfm\#ft14.

Welch, T. F., and S. Mishra. (2013). A Measure of Equity for Public Transit Connectivity. Journal of Transport Geography, Vol. 33, pp. 29-41.

Welch, T. F. (2013). Equity in transport: The distribution of transit access and -connectivity among affordable housing units. Transport Policy, Vol. 30, pp. 283-293. 
Transportation Research and Education Center

Portland State University

1900 S.W. Fourth Ave., Suite 175

Portland, OR 97201 